\title{
O terceiro livro do tratado De Arte Voluntatis de Juan Eusébio Nieremberg (1595-1658)
}

\author{
Paulo Roberto de Andrada Pacheco
}

Recibido: 25 de Noviembre de 2014

Evaluado: 10 de Diciembre de 2014

\section{Introdução}

“... el cumplir la voluntad de Dios es una agregación de todos los bienes, y así es el sumo bien de esta vida: una bienaventuranza anticipada, un paraíso en la tierra, una gloria en este valle de lágrimas”

(Nieremberg, 1957)

No último volume desta revista, publicamos o segundo livro do De Arte Voluntatis, do Padre Juan Eusébio Nieremberg ${ }^{1}$. Vale lembrar que, a obra, em seu conjunto, encerra um total de seis livros. Apresentaremos, neste artigo, o terceiro, que, segundo o próprio autor, na edição latina,

In Libro III. Cum voluntas pendeat ex rerum cognitione, docet, quo pacto informandas animus sit in alia sua potentia, scilicet, intellectu, ut facilius voluntas flecti sinat. Admonet in primis iudicandi peccata, \& opinionis damna: mox adhibet remedia: usum commodum potentiae intellectivae monstrat: praecepta ad id commendat nonnulla: modum invenit praevertendae in bonum opinionis: idoneum memoriae usum demonstrat: alia docet, quae iuvent faciliorem veritatis captum ${ }^{2}$ (Nieremberg, 1639: f. 5).

\footnotetext{
${ }^{1}$ Pacheco, 2014: 121-194.

2 “Livro III. Na medida em que a vontade depende dos objetos da cognição, aprende-se logo, de que modo a alma instrui sua potência, o intelecto, e dobra mais facilmente a vontade. Adverte primeiro a julgar os pecados e os danos das falsas crenças e acrescenta os remédios: o uso adequado da potência intelectiva; alguns preceitos e recomendações; o modo de encontrar e se ocupar das boas opiniões; o uso idôneo da memória; e ensina também como obter mais facilmente a verdade” (DAV, 1639: f. 5, tradução nossa).
} 
Este terceiro livro dedica-se a mostrar, pois, como " $a$ alma instrui sua potência, $o$ intelecto, e dobra mais facilmente a vontade”, e também faz algumas advertências e apresenta remédios para alma desordenada. Está dividido em 21 partes, sendo quatro temas ou proposições, oito ensinamentos, seis preceitos acerca do uso da opinião e três preceitos contra a opinião, organizadas da seguinte forma: Lemma I/Iuvanda est voluntas ingenio $^{3}$, Lemma II/Opinio multiplicat mala per ipsa bona ${ }^{4}$, Lemma III/Iniqua aestimatio rerum ab existimatione est ${ }^{5}$, Lemma IV/Mala ab opinione potius veniunt, quam e rebus ${ }^{6}$, Paedeusis I/Remedium opinionis est, cognosci ${ }^{7}$, Paedeusis II/Salutaris usus opinionis, \& intellectus ${ }^{8}$ (dividida em 6 praecepta topica in usu opinionis ${ }^{9}:$ Locus I/Ex comparatione fortunae $^{10}$, Locus II/Ex contingentia ${ }^{11}$, Locus III/Ex respectu finis ${ }^{12}$, Locus IV/Ex comparatione temporum $^{13}$, Locus V/Ab exemplo ${ }^{14}$ e Locus VI/Ex providentiae ratione ${ }^{15}$ ), Paedaeusis III/Distractio ipsius opinionis ${ }^{16}$, Paedaeusis IV/Veritatis observantia ${ }^{17}$,

\footnotetext{
${ }^{3}$ Primeiro Tema: A vontade deve ser ajudada pelo engenho (DAV, 1639, III, 1). O tradutor francês intitulou esta parte de "Primeira Proposição: que é preciso que a Vontade seja ajudada pelo Entendimento”. É interessante observar como substitui ingenio por “entendimento" (intellectus). A categoria engenho, porém, é um topos muito frequente no âmbito institucional e mesmo no ambiente histórico de produção do DAV; por isso, optamos por mantê-lo.
}

${ }^{4}$ Segundo Tema: A opinião produz muitos males por meio do bem mesmo (DAV, 1639, III, 2). Na tradução francesa, optou-se por: "Segunda Proposição: que é preciso que o Entendimento se defenda das imposturas da opinião e se corrija de seus enganos”.

${ }^{5}$ Terceiro Tema: A estima injusta das coisas provém da opinião que se tem delas (DAV, 1639, III, 3). A versão francesa optou por “Terceira Proposição: que é da falsa estima que temos das coisa que nos vêm os males”.

${ }^{6}$ Quarto Tema: Os males vêm mais da opinião do que das coisas (DAV, 1639, III, 4). No texto francês aparece assim: “Quarta Proposição: que os males vêm mais da Opinião do que das coisas”.

${ }^{7}$ Primeiro Ensinamento: O remédio contra a opinião é conhecê-la (DAV, 1639, III, 5). Optamos por

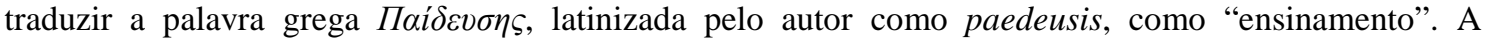
palavra significa punição, correção, disciplina. Mas, no contexto da obra, indica mais um ensinamento, uma máxima moralizante, do que propriamente uma ação disciplinar no sentido punitivo. A tradução francesa optou por: "Primeiro Preceito: que é um soberano remédio contra os males que a Opinião nos causa estudá-la e conhecê-la”.

${ }^{8}$ Segundo Ensinamento: O saudável uso da opinião e do entendimento (DAV, 1639, III, 6). A versão francesa ficou assim: "Segundo Preceito: concernente ao bom uso da Opinião do Entendimento".

${ }^{9}$ Tópicos Preceituais sobre o Uso da Opinião (DAV, 1639, III, 6,1-6).

${ }^{10}$ Primeiro Lugar: Da comparação com a Fortuna (DAV, 1639, III, 6,1).

${ }^{11}$ Segundo Lugar: Da contingência (DAV, 1639, III, 6,2).

12 Terceiro Lugar: Acerca dos fins (DAV, 1639, III, 6,3).

${ }^{13}$ Quarto Lugar: Da comparação dos tempos (DAV, 1639, III, 6,4).

${ }^{14}$ Quinto Lugar: Do exemplo (DAV, 1639, III, 6,5).

${ }^{15}$ Sexto Lugar: Da razão da providência (DAV, 1639, III, 6,6).

16 Terceiro Ensinamento: Separar-se da opinião (DAV, 1639, III, 7). O tradutor francês optou por chamar esta parte de "Terceiro Preceito: que devemos nos dedicar seriamente a nos distrair da Opinião". Vale dizer que a palavra distractio em latim significa divisão, discórdia, desunião. Traduzi-la por "distração" não é de todo errado, tendo em vista a conotação de "falta de atenção" que o vocábulo possui em português. No entanto, dada a possibilidade de se entender "distração” como divertimento, optamos por traduzir distractio como "separação".

${ }^{17}$ Quarto Ensinamento: A observância da verdade (DAV, 1639, III, 8). No texto francês esta parte foi traduzida por “Quarto Preceito: que é preciso buscar cuidadosamente a Verdade”. 
Paedeusis V/Sensus veritatis attingendus est ${ }^{18}$ (também dividida em 3 alia praecepta contra opinionem ${ }^{19}$ : Praeceptum I/Praemeditari mala ${ }^{20}$, Praeceptum II/Expectare mal $^{21} \mathrm{e}$ Praeceptum III/Timenda non confingere ${ }^{22}$ ), Paedaeusis VI/Usus memoriae ${ }^{23}$, Paedeusis VII/Inutilitas, \& curiositas mentis prohibenda ${ }^{24}$ e Paedeusis VIII/Cognitio divinorum maxime perficit intellectum ${ }^{25}$.

Vale notar que, para esta tradução que vem a público pela primeira vez em língua portuguesa, tivemos acesso, além do texto latino original, de 1639, também à tradução de 1657 feita pelo francês Louys Videl, que dividiu o DAV em dois volumes, cada um contendo três livros. Infelizmente, a segunda parte da tradução, ao que tudo indica (Hoefer, 1863), não chegou a ser publicada, restando-nos apenas os três primeiros livros traduzidos. Outro volume importante é o que contém a versão italiana do texto - Dell'Arte per ben reggere la volontà, insegnata dal Padre Gio: Eusebio Nierembergh della Compagnia di Giesu, Libri Sei, Trasportati dalla Latina nella Lingua Italiana. All'Illustrissimo e Reverendissimo Signore Monsignore Daniello Delfino, Vescovo di Filadelfia, \& Eletto Patriarca d'Aquileia - traduzido por Gabriello Baba e publicado em 1669, em Veneza.

Por fim, antes de apresentarmos o texto propriamente dito, lembramos que, ao longo da tradução, tomaremos o cuidado de apontar, em notas de rodapé, questões referentes à tradução de modo a garantir ao leitor uma compreensão mais adequada e crítica do pensamento nieremberguiano.

\footnotetext{
${ }^{18}$ Quinto Ensinamento: Entrar em contato com o sentido da verdade (DAV, 1639, III, 9). Na versão francesa aparece “Quinto Preceito: que devemos penetrar o verdadeiro sentido da Verdade”.

${ }^{19}$ Outros Preceitos contra a Opinião (DAV, 1639, III, 9,1-3).

${ }^{20}$ Primeiro Preceito: Premeditar os males (DAV, 1639, III, 9,1). A tradução francesa traz, na verdade, o seguinte título: "Preceitos Particulares contra a Opinião - Primeiro Preceito: que é preciso premeditar os males”.

${ }^{21}$ Segundo Preceito: Esperar os males (DAV, 1639, III, 9,2). Em francês o título ficou assim: "Preceitos Particulares contra a Opinião - Segundo Preceito: que é preciso esperar os males”.

${ }^{22}$ Terceiro Preceito: Não inventar os temores (DAV, 1639, III, 9,3). O texto francês traz a seguinte tradução: "Preceitos Particulares contra a Opinião - Terceiro Preceito: que é preciso sentir apreensão através da razão e não imaginar motivos de temor”.

${ }^{23}$ Sexto Ensinamento: Uso da memória (DAV, 1639, III, 10). Em francês a tradução foi: "Sexto Preceito: que podemos fazer bom uso de nossa memória para não sermos surpreendidos pelos males”.

${ }^{24}$ Sétimo Ensinamento: Proibir a inutilidade e a curiosidade da mente (DAV, 1639, III, 11). O tradutor francês optou por nomear esta parte assim: "Sétimo Preceito: que é preciso nos abster do estudo das ciências vãs e das curiosidades inúteis”.

${ }^{25}$ Oitavo Ensinamento: Conhecer as coisas divinas aperfeiçoa sumamente o entendimento (DAV, 1639, III, 12). Na tradução francesa aparece assim: "Oitavo Preceito: que o conhecimento das coisas Divinas aperfeiçoa o Entendimento”.
} 
20 De Arte Voluntatis

\author{
A ARTE \\ DE CONDUZIR
}

A VONTADE

LIVRO TERCEIRO

PRIMEIRO TEMA

A vontade deve ser ajudada pelo engenho

Adquirimos, por nossa Vontade, uma das mais notáveis vantagens que ela poderia pretender. De escrava que ela era, nós a tornamos soberana; ela deixou de estar sujeita à violência das paixões. Nem ao desejo, nem ao temor, nem à esperança, por quem, como por tantos Tiranos cruéis, ela era incomodada sem cessar e que, a partir de então, deixaram de incomodá-la. Ela está protegida de todos os obstáculos que poderiam lhe ser suscitados pela malignidade da Fortuna. Desde então, está em seu poder atingir o objetivo a que aspira, e não será difícil manter-se em plena posse de seu repouso. Mas, precisa de uma ajuda, que lhe confere as habilidades necessárias para conseguir; que sustente seus bons movimentos; que mantenha seus esforços e cumpra, igualmente, o papel de suporte e de guia. É preciso que o entendimento a esclareça e a fortaleça; mas, certamente, é preciso também que ele seja esclarecido; que ele aja firmemente e com certeza sobre o discernimento das coisas; que ele seja puro das más persuasões que, como tantas outras sombras, ofusca sua luz; que, rejeitando o erro e a mentira, ele seja somente capaz das impressões da verdade. Sem dúvida, a Vontade pode desprezar, pode odiar a Fortuna, e não ser infeliz por isso; muitas vezes, é exatamente neste desprezo e neste ódio que consiste a felicidade. Mas, se o entendimento ${ }^{26}$ seduzido e corrompido pela opinião se persuade do contrário, se ele se deixa encantar pelo brilho dos bens e das vantagens da Fortuna, é certo que a Vontade - que o escuta e consulta-o como se fosse seu oráculo, que adota e determina, segundo seus pareceres, a estima que deve fazer das coisas - não se resolverá facilmente a tomar outro partido e não se afastará de seus sentimentos, sem se fazer violência. Ela se acreditará feliz, a partir do testemunho e da fé daquele que a aconselha; e então, ela só conseguirá ser feliz realmente quando fizer experiência da infidelidade da Fortuna, e quando ela conhecer que sempre estará em perigo enquanto crer que a Fortuna é firme. Mas, porque há muito o que dizer sobre a diferença entre esta infeliz felicidade que depende da Fortuna e esta outra rara e maravilhosa que procede da Virtude - a primeira é não apenas ligeira e inconstante, como também é cega; enquanto que a outra é constante e esclarecida; aquela só nos chega fortuitamente, e essa nos é infalível, porque é um efeito de nossa razão e de nossa prudência -, é preciso que a Vontade seja fortemente assistida pelo Entendimento, para

${ }^{26}$ Optamos por traduzir “intellectus”, como aparece no original latino, por entendimento. 
não se enganar nessas escolhas; e que ele lhe tire uma parte da pena que ela teria em discernir a falsa da verdadeira felicidade. É preciso que ele lhe faça conhecer, de início, as coisas capazes de produzir sua alegria; a fim de que, estando livre e aliviada do cuidado de procurá-las, ela aja mais alegremente nisso e corra, por vontade própria, para abraçá-las. Assim, por mais que a opinião lhe represente como duro e penoso o caminho para chegar ao repouso, ela tirará da Razão aquilo que lhe permitirá encontrar espontaneidade e facilidade; e o conhecimento que ela terá da grandeza e da dignidade de seu objetivo mudará todos os espinhos em rosas. Mas, com a assistência do Céu sem dúvida, ela tem necessidade da Graça -, de onde lhe deve vir seu maior e mais seguro socorro, de onde ela deve esperar o feliz sucesso de todos os seus empreendimentos; e, ainda mais, pois é quem opera tudo aquilo que há de bom em nós; pois, sem esta ajuda, nós sofreríamos inutilmente e erraríamos numa noite escura, por mais esforços que nossa Razão fizesse e por maior que fosse a luz que nos iluminasse.

É pelo Entendimento que a Vontade se instrui acerca da condição e do estado das coisas; ele é o órgão e o instrumento necessário de todos os seus conhecimentos; ele é, para dizer com poucas palavras, suas orelhas e seus olhos; todo partido que ele toma é abraçado por ela sem hesitação; ele lhe permite todos os seus movimentos e a atrai a tudo, da mesma forma como os elos de uma corrente puxam uns aos outros. A perfeita confiança que um Príncipe tem em seu Ministro, sob os cuidados de quem ele repousa da condução de seu Estado, é a mesma confiança que a Vontade tem, em todas as coisas, no Entendimento. Ela se reporta em tudo a ele; ela permanece inteiramente confiada a ele; e disso depende, sem dúvida, o estabelecimento de sua alegria; porque, segundo ele lhe imponha ou lhe fale verdadeiramente, e que seu testemunho seja falso ou fiel, ele produz diversamente sua inquietude ou seu repouso. É através dele que as coisas se representam e como que se explicam para a Vontade. Ele é seu intérprete e sua língua; mas tanto língua que fere, como língua que cura, tanto língua mortal, como língua que salva; que faz a Vontade sofrer, fazendo-lhe tomar por mal aquilo que não é; que também alivia a Vontade, livrando-a de males verdadeiros; da mesma maneira que este animal cuja língua é um bálsamo para todas as suas chagas e que só precisa lamber a ferida para se curar ${ }^{27}$. O entendimento produz o mesmo efeito sobre tudo aquilo que ofende e fere a Vontade; ele alivia seus males; ele cura suas chagas, por assim dizer. Ora, como até aqui instruímos sobre os meios infalíveis para estabelecer sua paz e sua alegria, nos cuidados seriam inúteis se não os levássemos, em seguida, à instrução do Entendimento, acerca das funções que lhe são próprias nesse sentido. Importa-nos, para isso, saber que somos infelizes de duas maneiras, que a miséria se introduz em nós por duas vias principais, seja porque nos propomos maus objetos para nosso amor; seja porque ficamos descontentes, sem cessar, na estima que temos das coisas. Estes são os dois meios através dos quais somos naturalmente frágeis. E é por isso, sem dúvida, que nosso cuidado maior deve ser no reparo e na defesa. Devemos nos abastecer de tudo aquilo que é capaz de nos manter em segurança; munir-nos, nos fortificar de boas e sérias meditações, de sólidos e sábios pensamentos, que podem nos servir em todas as circunstâncias difíceis que encontrarmos; que pratiquemos e reduzamos seu efeito quando se fizer necessário. Assim como nós trazemos conosco pedras preciosas para nos garantirmos de diversos acidentes, e a Virtude nos preserva dos relâmpagos e trovões; é preciso que tenhamos continuamente em nosso espírito aquilo que pode nos

\footnotetext{
${ }^{27}$ No original latino, Nieremberg (1639) se refere ao cão: "et quemadmodum canina lingua id sanat, quo potest pertingere" (p. 211).
} 
proteger das tempestades e dos relâmpagos da Fortuna; de salutares máximas, tiradas, senão dos oráculos do Céu, pelo menos das mais puras fontes da sabedoria mundana.

A pobreza toda rasgada e em trajes tão infelizes a ponto de causar medo aos homens, vem nos acolher? Pratiquemos esta arte tão salutar, que acabamos de recomendar que seja bem empregada, conforme esta verdade: Só é pobre aquele que não sabe se contentar com pouco e que sabe ser pobre. Uma tão feliz reflexão, e que talvez nunca nos tenha vindo ao pensamento, nos assegurará, sem dúvida, e nos arrancará todo o temor que poderia nos apanhar de início. Mas acrescentemos ainda que a Pobreza nos importuna e nos pesa, que temos uma dificuldade enorme para suportá-la, mas lembremo-nos de que a Razão nos ensina também que não podemos ficar sobrecarregados de algo vazio e sem carga de nada, que cria tão pouco embaraço, que é tão leve, visto que ela não usa nem mesmo roupas. E, além do mais, quanta aparência pode haver no fato de querermos nos aliviar através do ouro, que é o mais pesado de todos os metais? Aliviarmo-nos de um fardo para carregar outro ainda mais pesado e incômodo? A Pobreza não pesa nada, com efeito; cansamo-nos de fantasiar e, pior ainda, acabamos deixando-nos levar pela opinião. A Pobreza é como um homem de guerra que, indo se alojar numa casa, assusta seu anfitrião à primeira vista; mas depois, quando tira e se desveste de tudo aquilo que o tornava terrível, se torna familiar e alguém de seu costume. A Pobreza nos assusta verdadeiramente no início; mas tão logo ela permanece um pouco em nossa casa, tão logo nos acostumamos com ela, e consideramos as vantagens que ela nos oferece, ela se torna agradável e cara; e não é sem nos lamentarmos que nos resolvemos a deixar sua companhia. Será que estamos pressionados pelo desejo de ser felizes? Mas, o que costumo escutar é esse tipo de felicidade que não nos deixa felizes de fato, e que é puramente obra da Fortuna. Tão logo a conquistamos acusamos de injustiça o nosso amor próprio, por nos ter feito desejar uma prosperidade infeliz e nos fazer buscá-la ao preço de nossa salvação. Escutemos a Razão, fortalecida pela experiência, que nos diz que a má sorte vem, ordinariamente, depois da boa, e é uma sequência infalível dessa última. Não nos parece extraordinário e raro que um cego guie outro? E não seremos nós também muito ridículos ao depositarmos nossa fé neste cego, e não temer, seguindo-o, nos perder ou cair num precipício? A Fortuna vendo que a Pobreza é incapaz de fazer o mal a um Pobre, e vendo que ele está sempre protegido de suas injúrias por causa do privilégio de sua condição, tem essa perigosa fineza de lisonjeá-lo e lhe dar grandes bens para que, dessa forma, ele deixe entrar a miséria que os acompanha, e fazê-lo cair nas emboscadas de onde será impossível retirá-lo. Por que nós nos ligamos tanto ao amor aos bens, se a partir do momento em que nos ligamos a eles, nós nos separamos da Virtude, nos abandonamos ao vício, e nos tornamos malvados? Que isso nos faça lembrar que o avaro não é bom para ninguém, nem mesmo para si mesmo. Foi-nos recusada alguma honra? Fomos decepcionados em nossas pretensões e esperanças? Lembremo-nos, o mais cedo possível, que se não temos aquilo que desejamos, temos aquilo que não deveríamos desejar. Ao invés de ficarmos chateados com aquele que reprimiu nossa ambição, deveríamos ficar-lhe gratos; certamente, temos muita obrigação para com ele, visto que ele, quando faz isso, age da forma que somos obrigados a agir conosco mesmos. Temos que ser bastante contidos, temos que ter bastante poder sobre nós, para que não peçamos nada à Fortuna, e que só lhe peçamos que não nos dê nada. Só isso podemos obter de nós mesmos; porque todo o resto ela consegue com seus movimentos, com seu ofício. Não será isso motivo suficiente para nos sabermos injustos quando lamentamos? Será que pretendemos repousar realizando nossos desejos? Quando fazemos isso, tomamos um caminho totalmente contrário, que nos levará, mais à frente, 
a problemas. Não sabemos que a cobiça é uma inimiga com a qual nunca há paz ou trégua? Não sabemos que a única maneira para acalmá-la não é com a posse, mas com a recusa? Aqueles que foram perfeitamente instruídos e que rejeitaram aquilo que desejamos, sabiam que há incomparavelmente mais ganho no não querer aquilo que temos do que em obter aquilo que desejamos; que não há menos inquietude e pena em possuir as coisas do que em buscá-las. Aproveitemos esta instrução e o exemplo desses; entendamos que é isso que é ser feliz - não ter obrigação nenhuma com a Fortuna, visto que suas liberalidades nos arruínam - e essa é a maior glória e a maior segurança: ser mal com ela, mais do que agir bem com ela, e saber que suas perseguições são mais vantajosas do que seus favores. Estabeleçamos toda a nossa alegria não apenas em não ter coisas que dependam dela, mas em não as desejar. O que quer que o mundo diga, não há felicidade maior do que esta; é nisso que, verdadeiramente, consiste aquilo que o mundo chama de boa Fortuna.

Assim como os animais domésticos, quando estão em cólera, só conseguem se acalmar quando ouvem a voz das pessoas que eles conhecem, é preciso que acalmemos a violência das paixões através das verdades e das máximas que lhes sejam conhecidas e familiares, que possamos empregar em todas as vezes que for necessário, e que sempre as tenhamos nas mãos, para nos servirmos delas como quem se serve de um escudo contra os assaltos e os esforços da Fortuna. Os Pilotos preparam, durante a calmaria, as que coisas que lhes são necessárias para se garantirem durante a tempestade; é preciso assim também nos prevenirmos na prosperidade, quando estamos entre as carícias e os favores que recebemos da Fortuna, daquilo que nos defende de suas injúrias, e nos protege das setas de sua inconstância e de seu rigor. Governando nossas paixões dessa maneira, e as acostumando à voz da razão, elas se organizarão segundo sua vontade, elas lhe obedecerão aos movimentos; e do mesmo modo que certas flores seguem o Sol, e giram na mesma medida em que ele gira, elas seguirão a luz da Verdade que, esclarecendo nosso espírito, fará desaparecer os fantasmas e as ilusões que a opinião havia formado ali; nos colocará numa rota feliz, onde não encontraremos nada que nos assuste ou que nos cause repulsa; e nos descobrirá as imposturas desta inimiga de nosso repouso, que, não se contentando em nos fazer sofrer através da apreensão de uma enormidade de males que ela cruelmente inventou, é ainda tão enganadora e de tão má fé, não somente a ponto de fazer com que não vejamos como mal os males que cometemos e nossas próprias faltas, mas fazendo-nos arranjar desculpas para tê-las cometido e, por uma depravação extrema, as louvar e as colocar na mesma altura que os bens. Sem dúvida, é nisso que estão nossos maiores males, se não forem os únicos que devemos temer realmente. Todo o resto de coisas é indiferente de si e não tem nenhuma determinação. Elas assumem a tintura e o rosto segundo mais nos agrada; segundo o emprego que se lhes dá, se pode fazer bens ou males; elas aproveitam quando as deixamos na sua pureza natural; mas elas danificam, se se as corrompe e utiliza de forma inadequada. Ora, como, seguindo a Verdade, mantemonos no caminho certo que conduz ao bem; como estamos certos de que ele a acompanha para onde vai e que ele é inseparavelmente ligado a ela, é preciso que o Entendimento a proponha à Vontade, que deverá ser seu primeiro objeto, a fim de que, chegando, através dela, ao conhecimento do bem, ela se inflame com o desejo de sua posse; ela se excite em seu amor e em sua busca.

\section{SEGUNDO TEMA}

\section{A opinião produz muitos males por meio do bem mesmo}


Mas, o Entendimento não seria capaz de se dispensar dos ofícios que deve à Vontade, nem lhe dar a menor segurança, se ele não se corrigir de dois defeitos de que ele é, ordinariamente, culpável na relação com ela: excitá-la com falsas imagens, que lhe fazem fazer esforços inúteis, e a fazem correr atrás de fantasmas; e apresentar-lhe bens sob uma aparência frágil e lânguida, que não apenas ela não é capaz de tocar, como também mais lhe causa desgosto do que lhe imprime desejo. É por causa desses dois inconvenientes que ela é privada da ajuda e do suporte que espera dele. Nesse sentido, descobriremos agora quais são os males que lhe vêm do primeiro, e daremos espaço também para mostrar as perigosas consequências que o outro traz consigo. Porque, ele tanto condena aquelas que merecem mais estima, como louva altamente aquilo que é mais digno de reprimenda. Às vezes, sua injustiça age até ao ponto de lhe cobrar o bem com o mal, e a lhe fazer tomar o mal como se fosse bem. Desta impostura, como se viesse de uma fonte envenenada e mortal, derivam todas as nossas penas e nossas infelicidades; por ele, concebemos horror por aquilo que deveríamos buscar ardentemente. E aquilo que, naturalmente e por si mesmo, seria o objeto de nosso amor, se torna o tema para o nosso ódio. Assim, falsificando tudo aquilo que nos dá, e nos persuadindo que há males onde não há, ele enche nosso espírito de terror, e nos faz sofrer todas as angústias que nos dão os males verdadeiros. Mas, há piores ainda: por uma maravilha desconhecida pela Natureza, essas angústias se mantêm e crescem através de seu contrário, pela representação e a imagem dos bens que havíamos esperado e que, depois, não encontramos, ou que, sendo encontrados de maneira diferente daquela que havíamos concebido ou estando acima de nossa opinião e de nossa expectativa, produzem em nós mais motivo para dor e para desespero e nos tornam, necessariamente, infelizes. Mas, cremos ser menos quando os obtemos? Saibamos que a Vontade, por ser plena e satisfeita, nem sempre é feliz. Esta aparência de bondade que vemos nas coisas, e que só é obra de nosso capricho, é extremamente frágil e delicada, é uma flor que se desfaz ao menor toque; que, bem longe de ter firmeza e dureza, não tem nem mesmo consistência; ela se funde e se perde entre nossas mãos; ela passa e escorre como a água; ela é outra quando a possuímos, diferente daquilo que acreditávamos quando a buscávamos. Acrescentemos ainda que o desejo e o temor só são separados por uma muito pequena distância; e, por assim dizer, só há um passo entre um e outro. Tão logo concebemos o desejo de uma coisa, começamos a temer sua perda, e então ela começa a nos causar inquietude. Sendo assim, que repouso, que satisfação podemos pretender dos bens? Se eles nos causam tanto sofrimento, seja na paixão por adquiri-los, seja na apreensão por perdê-los? Verdadeiramente, seríamos incapazes de estabelecer nisso uma alegria sólida. Por causa do mesmo engano da Fortuna - que nos faz supor bem o que é mal -, supomos prazer o que é tristeza.

Qual dos dois, nesse momento, achamos ser mais feliz? Aquele que é desprovido de todas as suas esperanças? Ou aquele cujos desejos foram inteiramente realizados? É sobre isso que a Razão nos impede de deliberar; ensinando-nos que a condição deste é muito mais miserável que a daquele ${ }^{28}$. Aqueles que ainda não conhecem nada da maldade da Fortuna, e que não experimentaram ainda o engano que lhe é ordinário - de nos dar um mal como se fosse um bem - resistirão, no início,

\footnotetext{
${ }^{28}$ No sentido que não há motivo para uma deliberação, quando estão tão claros os fatores em jogo. Devese simplesmente obedecer.
} 
estou certo, a este sentimento e o acharão pouco razoável. Mas, que eles saibam que, por um mal que eles imaginam, foi frustrado o efeito de sua expectativa; há dois grandes e muito sensíveis para obter: não ter o bem que eles esperavam e, por uma infalível e cruel troca, ter em seu lugar um mal a que não esperavam. E como a dor que se recebe de um golpe forte aumenta quando é dado uma segunda vez, esses dois açoites igualmente pesados que a Fortuna nos dá, nos surpreendem e nos assustam de tal maneira que é melhor que a razão nos proteja fortemente e nos preste uma poderosa ajuda, para nos salvaguardar de sermos destruídos. Diz-se que Aníbal ${ }^{29}$, estando em Creta, e tendo que se defender da avareza dos Gortínios ${ }^{30}$ que desejam seu ouro, tomou o cuidado de encher de chumbo alguns jarros que ele usou como compromisso de sua fé e que, em seguida, ele depositou no Templo de Diana; persuadindo-os, através disso, de que lhes havia realmente feito mestres de seus tesouros. Se desejássemos esses jarros, crendo-os realmente cheios de ouro, ficaríamos muito menos encolerizados de encontrar apenas chumbo se, não chegássemos nem mesmo a tê-los em mãos, porque alguém no-los subtraísse. Esta é a fineza da Opinião: ela nos dá chumbo como se fosse ouro, seus efeitos são muito contrários às suas aparências e às suas promessas. Não lhe sendo suficiente nos ter feito decair de nossas esperanças, ela acrescenta uma segunda dor àquela que ressentimos após a queda: ela nos sobrecarrega e nos aflige com um novo mal, ainda mais desagradável e doloroso, que não havíamos sequer previsto; e então fazemos experiência dessa verdade, segundo a qual os mais perigosos golpes que recebemos da Fortuna são aqueles que nos chegam inopinadamente e que, não apenas sua ira e suas ameaças não os precederam, como também vêm, frequentemente, logo depois de uma boa aparência que nela identificamos. Depois disso, será que ainda seremos tão contrários a nós mesmos a ponto de ter alguma confiança que seja nos conselhos da Opinião? Será que não desconfiaremos dela como de uma mortal inimiga? Temos muita razão em considerá-la assim, visto que, não se contentando com os males que a Fortuna nos suscita, ela é ainda mais maligna ao fazê-los crescer, acrescentando a eles agruras e amarguras. É dela que procedem todas as nossas tristezas e todas as nossas inquietudes. Seja porque ela converte os bens em males, seja porque ela muda os males em bem, ela sempre nos faz sofrer igualmente; ela é sempre uma perpétua Operária de problemas e penas. Se, às vezes, ela nos dá algum motivo de alegria - o que é muito raro, sem dúvida -, ela imediatamente mistura a isso um pouco de fel, corrompendo-a e envenenando-a. Não há resolução nossa de praticar a Virtude que ela não seja capaz de suspender e romper, através da apreensão que ela nos suscita diante das dificuldades e dos espinhos que nos faz supor existir na prática da Virtude. Para nos desviar do bem, ela o diminui em nossa estima; pelo contrário, ela aumenta o valor do mal, e chega mesmo a fazer passar por um mal aquilo que não é. Aqueles que pretendem desculpá-la, nunca alegam que seja ela a lhes causar o contentamento, visto que só é feliz aquele que crê ser. É nisso que ela é ainda mais criminosa: sendo certo que ela não é capaz de produzir contentamento que não seja falso, e que ela só atrai mil verdadeiros desprazeres, e que, quando ela consegue ser inocente quanto a isso, produzindo efetivamente algum bem, ele sempre será escondido e coberto pela enormidade de males que virão em seguida. Para que vamos dissimular? Ela se opõe, com tudo o que possui, ao nosso repouso e à nossa alegria; ela só nos sabe fazer mal.

\footnotetext{
${ }^{29}$ Ou Hanibal (247 a.C.-183 a.C.), foi um general e estadista cartaginês, e é considerado um dos maiores estrategistas militares da história.

${ }^{30}$ Os habitantes de Gortina, localidade da ilha de Creta.
} 
Certamente, o melhor que poderia acontecer a quem a escuta, a quem a segue, é cair num abismo de dor e de miséria.

\section{TERCEIRO TEMA}

\section{A estima injusta das coisas provém da opinião que se tem delas}

Mas, nós escutamos e seguimos esta perigosa Conselheira; nós nos dedicamos com tudo a nos tornarmos infelizes. Como se nossa ruína fosse nosso desígnio, nós a fazemos o objeto de todos os nossos cuidados; parece que só usamos a Razão para nos perverter; e parece que o verdadeiro uso de nossa luz seja nos levar para as trevas. De onde vem esta desordem? Será que é do fato de sermos prevenidos quanto às imposturas da Opinião? Ou será que é porque ela nos aconselha e nos guia? Vejamos um quadro raro e natural dos monstruosos efeitos que ela produz no espírito dos homens. Pensemos em $\operatorname{Haman}^{31}$ e no alto ponto de grandeza no qual a Fortuna o colocou na relação com Assuero; vejamos como ela parecia só ter honrarias e bens destinados a ele; como ela o obrigava constantemente, para fazer a ele, como é seu costume, um memorável exemplo de sua inconstância. Enfim, pensemos nele revestido de todas as vantagens que o favor dos grandes Príncipes adquire para aqueles que são elevados ao mesmo grau que eles. Não ficaríamos extremamente impressionados de nos darmos conta de que sua ambição só conhecia tudo isso por causa de muito pouca coisa; que ela não se satisfazia com os respeitos que lhe rendiam todo o povo; e que ela se afligia com a recusa que um simples particular fazia a ponto de dobrar os joelhos diante dele? De onde lhe viam uma tão extraordinária desordem, senão das ilusões da Opinião? E a que mais seria necessário relacionar uma tão estranha doença? Se durante o tempo em que ele era ainda uma pessoa qualquer, na mediocridade de sua primeira sorte, se lhe tivesse sido oferecida a menor parte das coisas cuja abundância e plenitude, agora, lhe causavam problemas; se ele tivesse tido a honra de se aproximar de seu Príncipe e receber a mais leve marca de sua benevolência; se ele tivesse tido a chance de se empregar perto de sua pessoa, ou recebesse qualquer outro favor que, nunca antes, ele pudesse ter pretendido; será que ele teria sido tão inábil, para não dizer tão extravagante, a ponto de não levar em consideração as reverências de Mardoqueu ${ }^{32}$, preferindo uma cerimônia vã e inútil às vantagens reais e sólidas? Será que sua alegria seria maior ao vê-lo prosternado diante dele do que a vê-lo elevado ao cume dos bens e das honras? Como é que ele mudou tanto? Quem teria arrancado de sua estima o preço e o brilho da grandeza, para lhe dar coisas abjetas e vis? Através de que novidade a ambição - que, ordinariamente, levanta os olhos em direção ao que é mais alto, e que só se excita com aquilo que a ultrapassa - se inquietaria com ele, com aquilo que estava tão acima dela? E como é que um Escravo, não o honrando absolutamente em nada, poderia imprimir algo em seu espírito, já cheio de glória por ser o objeto da adoração pública? Estão justamente aí as marcas da fragilidade de um Entendimento corrompido pela Opinião; esses são seus verdadeiros Sintomas. Como ela é infiel e enganadora; como ela muda e se

\footnotetext{
${ }^{31}$ Ou Amã que, segundo o relato do livro de Esther, é filho de Amedata e foi elevado em dignidade por Assuero que, ao que tudo indica, é o rei persa Xerxes I (c. 519 a.C.-466 a.C.).

${ }^{32}$ Segundo o relato bíblico, era tio de Esther e ocupou um lugar de destaque no governo de Assuero, após a morte de Amã.
} 
fantasia em tudo aquilo que ela representa; ela, primeiramente, os vestiu de grandezas e de riquezas, os revestiu de uma aparência pomposa que o fascinou; e, em seguida, por uma mudança repentina, destruindo sua própria obra e a despojando dos ornamentos que ela lhe emprestou, ela os desnuda e lhes faz parecer um nada. Do abuso que o levou a acreditar que poderia encontrar sua satisfação nas coisas mais elevadas, ela o fez cair no erro de pensar que a poderia encontrar nas mais baixas. Assim, somos capazes de movimentos diversos e contrários. Estimamos falsamente as coisas, tanto quando as elevamos ao mais alto dos céus, como quando as abaixamos até ao fundo dos abismos; e tudo isso porque a Opinião nos governa e, para bem dizer, que brinca conosco.

Certamente também é ela que dá às coisas do mundo esta aparente beleza que nos encanta; é dela e não da Verdade que elas recebem o lustro e esse brilho que nos deslumbra. É das falsas impressões com as quais ela preocupa o Entendimento que procedem os descontentamentos e os erros nos quais ele cai; e disso advém, em seguida, a cegueira que faz com ele estime bens que só têm como fundamento seu capricho e que só subsistem por causa do seu desejo. Aqui, descobriremos de forma adequada as imposturas da Opinião, e convencê-la do fardo e da falsa aparência que ela empresta às coisas! Sem, para isso, empregar a autoridade dos Oráculos humanos e divinos, tiraremos a prova de sua própria boca; e será suficiente que, nos tormentos que ela sofre ao não conseguir se satisfazer, nós a ouçamos se desmentindo solenemente, e gritando com dor, que todas as coisas do mundo são um nada. Voltemos àquele em cujo espírito ela produziu o maior exemplo de sua tirania, àquele por quem a Fortuna testemunhou tão grandes paixões a ponto de ele não ter tido outros meios senão escolher Assuero como seu favorito. Pensemos nele entre seus parentes, cheio de despeito e de raiva, pronunciando estas palavras dignas da mais severa Virtude da Academia e do Pórtico, eu estimo menos que nada tudo o que tenho $^{33}$. Ele contou suas riquezas como se fosse nada, mesmo sendo ela tão abundante que a mais ardente avareza poderia ser saciada; ele não levou em consideração os presentes e as liberalidades da Natureza; ou a feliz e florescente família; ou a vantagem da qual os homens se vangloriam normalmente ou com a qual mais se alegram; ele não se sentiu em nada tocado com suas honras e dignidades que o elevavam a um tal ponto que, abaixo de si, só conseguia ver a grandeza que havia feito. Onde estão Zenão e Crisipo que tiveram os mais nobres sentimentos quanto às coisas do mundo $?^{34} \mathrm{E}$ que as condenaram como ninguém, com o mais absoluto

\footnotetext{
33 O original latino, na verdade, afirma, desde o princípio do capítulo, o seguinte: “Istum enim mundanarum rerum colorem, istum splendidum gestum obduxit, non veritas, sed opinio perversa, transversum iudicium agens, magna bona pro libidine, non pro veritate commentans. Capio iam huius vanitatis fidem, non à Lycaeo \& porticu Stoicorum, non à Cruce IESU; non, inquam, ab Philosophia, non $a$ virtute, non a fide, non ab ipsa Dei sapientia; sed à mendacissimis, ab ipso mundo, ab ipsis vanitatis mancipiis”, que pode ser traduzido da seguinte forma: “de forma que não é a verdade, mas a opinião perversa não escoltada pela verdade, que conferiu esta mundana cor às coisas, e as dispôs desta esplêndida forma, fazendo com que se formasse um juízo contrário que representasse grandes os bens em prol da libido. Tomo, agora, como confirmação desta verdade, não da Academia, ou do Pórtico dos Estóicos, não da Cruz de JESUS, não da Filosofia, não da virtude, não da fé, não da sabedoria mesma de Deus, mas da mentira mesma do Mundo, dos escravos da vaidade”. Louys Videl praticamente resumiu tudo na expressão "Oráculos humanos e divinos”.

${ }^{34}$ É interessante notar que, no original latino, Nieremberg escreve: "Quid amplius a Zenone aliquo, aut Socrate desiderares?”. Referindo-se, portanto a Zenão de Cítio (334 a.C.-262 a.C.), o filósofo grego que fundou o Estoicismo, e a Sócrates (469 a.C.-399 a.C.). Mais à frente, no mesmo capítulo, Nieremberg anota: "Quotusquique ex porticu Chrysippus aliquis, ita ad exaggerationem, ita ad contemptionem rerum
} 
desprezo? Assuero acrescentou ainda que isso foi o que descobriu o mal que a Opinião lhe causou; a ponto tal que Mardoqueu, o Judeu, não se prostrará diante de mim. Na suprema constituição de fortuna na qual ele estava, e na qual ele quase podia dizer que tinha tudo, ele considerou nada possuir, não tendo sequer os respeitos e as submissões de um Escravo; não tendo nem mesmo uma coisa sequer digna de seu pensamento e que, razoavelmente, pudesse deixar alguma marca em seu espírito. Algumas vezes, o brilho das estrelas desaparece e parece quase que tenha se apagado; mas é quando o Sol as ofusca com a plenitude de sua luz e enche todas as coisas com seu esplendor. Portanto, quão baixas e vis podem ser as riquezas e as grandezas, visto que um nada as faz desaparecer da lembrança daquele que as possuía em tanta quantidade? Muito frequentemente, aprendemos que os bens do mundo são caducos e perecíveis; mas isso é se os compararmos aos bens do Céu, aos que a Virtude produz, que são sólidos e constantes e cuja duração é eterna. Assim como não há motivo para espanto no fato de uma gota d’água não ser discernível nos abismos do Oceano, certamente não há de que se maravilhar com o fato de que as satisfações mais ligeiras que se saboreiam nesta vida nos pareçam um nada comparadas à perfeita alegria que esperamos na outra. Depois de tudo, ninguém nunca destituiu de valor tão potentemente as grandezas do mundo, nem as colocou tão abaixo do mundo mesmo, do que o inimigo de nossa salvação, através da boca de seu oráculo infiel e pernicioso, quando ele as prometeu todas ao Filho de Deus se ele se prostrasse à terra para adorá-lo. Poder-se-ia representar de forma mais expressa a sua vaidade? E não seria isso - oferecer-lhe um nada - algo como uma declaração bem autêntica do seu próprio nada?

No entanto, não pensemos que Amã tenha pronunciado essas palavras imprudentemente e de maneira solta; elas não caíram inopinadamente de sua boca; ele as meditou antes de as dizer; ele quis que seus parentes e amigos, expressamente chamados diante de si, fossem testemunhas de suas palavras. Ora, temendo que eles acreditassem que ele havia perdido o sentimento de sua felicidade, pelo esquecimento das vantagens que a compõem, estando certo de que as coisas se apagam de nosso coração tão logo se apagam de nossa memória, ele lhes disse em detalhes do que se compunham suas grandezas e riquezas, enumerando-as com exatidão e particularidade. Mas, por mais que elas estivessem num tão alto ponto que a imaginação só conseguisse chegar até a elas com muito esforço; por mais que não se conhecesse fortuna com o preço e a eminência da sua; ele não pôde impedirse de se lamentar. Aquilo que enchia os outros de admiração não foi capaz de satisfazê-lo; ele se achava o mais pobre e o mais infeliz de todos os homens; ele disse que não tinha absolutamente nada e, mais do que dizer, ele acreditava mesmo nisso. Como se a dureza de Mardoqueu pudesse passar para ele, ele se tornou insensível ao prazer que a grandeza traz; ele perdeu inteiramente o gosto das delícias e das Volúpias; e o desprezo que ele parecia receber de um Escravo foi o desprezo que ele deu às coisas mais preciosas e encantadoras. Ora, eu vos pergunto, em que tempo? Quando ele gozava plenamente? Quando sua cobiça era mais ardente, visto que seu objeto estava mais perto dela, a ponto de irritá-la e infectá-la pela simples visão, por assim dizer, da mesma maneira que aquela Serpente que mata com o simples olhar e leva seu veneno em seus olhos? Quando o favor da Rainha bem

humanarum animosam extulit vocem?”, que poderia ser traduzido da seguinte forma: “Quem, entre tantos, como Crisipo do pórtico, conseguiu mais vividamente levantar a voz para exagerar a vaidade e o desprezo que se deve ter pelas coisas humanas?”. O filósofo a que se refere é Crisipo de Solis (280 a.C.-208 a.C.), um dos mais conhecidos adeptos do Estoicismo, tendo assumido, inclusive, a direção da Escola do Pórtico. 
ajustado ao do Rei tornava o seu estabelecimento ainda mais firme e dava uma nova extensão às suas esperanças? Quando ele não tinha nem pensamentos nem lembrança alguma da morte, e sequer estava reduzido àquele momento fatal em que os homens, prestes a deixar a vida, rompem todo o comércio com o mundo, e renunciam seriamente à vanglória? Quando, não conhecendo ainda a Fortuna, ele a cria constante e fiel? Quando ele estabeleceu a felicidade na posse das honras e dos bens, não sabendo que eles perecem por si mesmos e são feitos de uma matéria caduca e frágil? Quando, recebendo as honras e os bens todos os dias, ele começou a acreditar que havia conseguido impor um tributo à Fortuna, considerando-os menos como efeitos de sua liberalidade do que como marcas de sua sujeição? Numa palavra, quando ele estava numa constituição tão poderosa, numa tão boa colocação, numa tão firme estabilidade, que nada parecia ser capaz de abalá-lo, e não houvesse lugar em seu espírito nem mesmo para a suspeita de sua ruína? Não obstante tudo isso, ouviu-se que ele tenha dito em alto e bom som que ele nada possuía; e o sentimento da Verdade foi tão forte em todos os que o escutaram que não houve um sequer que não tenha ficado de acordo com ele; ele não foi desmentido por ninguém. Nem mesmo sua mulher, que suspendendo sua natural paixão de mãe, não apenas não se escandalizou em nada ao vê-lo olhando para seus filhos sem amor e sem ternura, como também aprovou seu lamento e o achou cheio de razão. Seus amigos, se se podem chamar assim mesmo aqueles que só eram amigos de sua fortuna, aplaudiram o desprezo que ele teve pelas honras e pelos tantos bens. Será que, depois disso, ainda recearemos dizer que as coisas do mundo são nada? Visto ser uma verdade o fato que os ambiciosos e os avaros também as reconheceram assim. Se aquele que mais as estima entre os homens, se aquele que mais se deslumbra e se encanta com elas - as grandezas e as riquezas - as considerou como um nada em comparação com o nada mesmo, o que nós podemos pensar que elas devam ser se comparadas com o preço dos bens da eternidade? Se uma só centelha lhes fez perder todo o seu brilho, pode haver algo de sua aparência que se conserve diante do Sol? E, sobretudo, diante daquele em cuja presença o sol é sombra e não tem nem esplendor nem luz?

De onde lhes vem, portanto, essa graça que nos agrada tanto e que nos atrai tão poderosamente? Que faz com que cresça em nós essa estima que por elas temos? Certamente que é por causa de nosso capricho, por puro efeito do erro onde estamos de tomá-las por aquilo que não são. Nisso, somos como o amante de $\mathrm{Juno}^{35}$, tal como é representado nas fábulas: aquilo que abraçamos como sendo um corpo só tem a aparência de tal, é uma sombra pintada e colorida, é um nada que só é aquilo que fazemos ser, e que só tem a existência que nossa Opinião lhe empresta. Ela marca todas as coisas com caráter movente; ela não deixa nenhuma impressão firme; todas as suas imagens são inconstantes; assim, a figura do mundo passa, porque ela só é aquilo que nos parece ser. E ele passa com sua figura, da mesma maneira que a água que corre sobre uma pegada é retida nela apenas pelo tempo em que ela ali se mantém, mas se perde tão logo a água consegue passar. Nós fazemos os bens e os males apenas pela nossa Opinião; eles só são o que são na medida em que nós assim os imaginamos; e a partir do momento em que não os cremos mais como tais, eles cessam de o ser. Por uma deliberação de nosso espírito e por um conselho tomado de nós mesmos, concedemos magníficos títulos a coisas muito pequenas. Frequentemente, julgamos maravilhoso aquilo que não é nada; somos parecidos com os jogadores que,

\footnotetext{
${ }^{35}$ Na mitologia, Juno é a esposa de Júpiter.
} 
substituindo o dinheiro que não têm por folhas de papel sem valor, as fazem valer muito mais do que o que realmente valem; abusamos muito voluntariamente, tomando por um bem ou por um mal aquilo que não o é; e nosso abuso procede do fato de nos deixarmos governar pela Opinião. É consenso universal de todos aqueles que usam a palavra que se entenda por Leão um animal extremamente corajoso; e que a palavra que designe aquele que tem uma vantagem nobre como é a razão seja chamado homem, a quem foi dado o império sobre todos os outros animais ${ }^{36}$. Ora, assim como os nomes são vagos e indiferentes por sua própria natureza, assim como eles só se podem determinar por aquilo que agrada à fantasia ${ }^{37}$, da mesma maneira poder-se-ia chamar de Leão uma Lebre covarde e temerosa; ou chamar de homem o mais estúpido de todos os animais. Temos uma semelhante liberdade no dar nomes especiais para as coisas do mundo; e, por um consentimento universal, mas perverso, atribuímos mérito e grandeza àquelas coisas que só o são segundo a nossa estima e que, no entanto, consideradas em si mesmas, são frequentemente as mais abjetas e as mais vis. Esta desordem foi introduzida pelos mais malvados dos homens, pelos ambiciosos e pelos avaros. Foi culpa de sua invenção que se tenha valorizado as grandezas e as riquezas, que se lhes tenha imposto nomes gloriosos; e que não apenas fez com que passassem como bens, como também que fossem capazes de estabelecer soberanamente a felicidade. Disso é que nasceu este deplorável abuso de levar mais em consideração as honras do que os méritos; estimar mais o ouro do que o ferro; preferir a coisa menos útil do mundo àquela que a experiência verifica como sendo a mais necessária. Ainda mais: como isso foi feito de comum acordo com todos os homens, poderia acontecer, da mesma maneira, que todos eles mudassem de Opinião e tomassem uma via de sentimento contrária. Os Lacedemônios, entre os quais todos os outros povos estavam como que apenas na escola da Sabedoria, condenaram o Ouro publicamente, estimando que não servisse para nada. Para certos povos da Etiópia, o Ouro servia apenas para fazer correntes que prendiam criminosos e cativos. Eles preferiram, sem dúvida, que o Ouro prendesse o corpo, mais do que prendesse o espírito; eles preferiram ser Mestres do Ouro e criar leis para ele do que recebê-las dele. Certamente, fomos muito maltratados por aqueles que, por primeiro, estimaram as coisas; e podemos seguramente dizer que eles tiveram pouco cuidado quanto ao que concerne ao nosso repouso e foram muito invejosos de nossa alegria, a ponto de fazêla depender daquelas coisas que são difíceis de adquirir, que só conseguimos obter desconfortavelmente, e que são raras e difíceis. Não apenas eles parecem ter querido nos impedir todos os caminhos para a felicidade, como também temos motivos para acreditar que eles quiseram o sofrimento necessário e frequentemente inútil que se tem na tentativa de ser feliz tornasse a maior parte dos caminhos miseráveis. Nisso, não nos lamentaremos nunca o suficiente, seja de sua ignorância, que de sua malícia. Porque, se estivesse em nosso poder estimar as coisas como devem ser, teríamos

\footnotetext{
${ }^{36}$ No original latino, Nieremberg escreveu: "Placitum humanum fuit, hanc vocem, leo, fortissimum animal; istam, homo, sapientissimum notare"; o que seria melhor e mais simplesmente traduzido assim: "Foi consenso entre os homens que esta palavra, Leão, fosse um fortíssimo animal, e esta outra, Homem, significasse um animal sapientíssimo”; de fato, a construção utilizada por Louys Videl tornou o texto muito hermético e de difícil tradução. Seja como for, optamos por manter, como vimos fazendo, a mesma construção sugerida pelo tradutor para a língua francesa.

37 É importante que se esclareça que todas as vezes que aparece a palavra fantasia, Nieremberg a está utilizando referindo-se à potência da alma sensitiva de nome Imaginativa ou Fantasia. No ser humano, são essas as potências da alma sensitiva: os sentidos externos (visão, audição, olfato, tato e paladar), os sentidos internos (senso comum, fantasia ou imaginativa, memória e cogitativa), o movimento e os apetites.
} 
estabelecido a felicidade naquelas coisas que estão à nossa inteira disposição e que temos à mão; eles, por sua vez, a fizeram consistir naquelas coisas que a Natureza afastou de nós, e que ela nos escondeu. Eles negligenciaram as coisas que, nos sendo presentes e familiares, podem facilmente nos tornar felizes; e, ao invés de fazer nascer a felicidade em nós, eles quiseram que ela viesse de outro lugar, eles a fizeram nascer em terra estrangeira. Ela poderia ser nossa por nada; e eles fizeram com que nós a comprássemos a um alto custo. Que loucura foi termo encerrado a felicidade na posse do Ouro! Relegando-a às entranhas da terra; indo buscá-la nos abismos até chegar às portas do Inferno! Como é possível que, da terra da miséria, nos venha a felicidade?

Essa falsa e perigosa estima pelas coisas, até ao presente momento, nos causou bastantes males; ela nos foi muito malvada. Até ao presente momento, fomos enganados a respeito do seu preço e o fomos por nossa livre e espontânea vontade, por consentimento nosso. É preciso, daqui em diante, nos corrigirmos de um erro tão perigoso; revogar o tratado que temos com a Opinião, considerando-o muito injusto e com muita desvantagem para nós; livramo-nos de sua tirania e assumir sentimentos mais razoáveis do que aqueles que ela tem para conosco. Através disso, nos tornaremos felizes mesmo em meio à miséria; faremos experiência da Verdade das palavras de um Antigo $^{38}$ para quem, a pessoa que não falta com a prudência, não falta com $a$ felicidade $^{39}$. O quê? Pensamos que seria extremamente difícil mudar os sentimentos humanos; e que haveria mais temeridade que razão nesse empreendimento? Para não mentir em nada, é absolutamente impossível; mas, se não há como chegar à meta, a partir do consentimento dos povos, só nos resta procurar o nosso consentimento; e não podendo produzir este bem geral, resta que, pelo menos, o produzamos para nós, em particular. Há esta diferença entre as palavras e os pensamentos: as primeiras, tendo uma significação determinada, por um comum acordo entre todos os homens, não somos capazes de mudar, a não ser que seja por uma deliberação comum; mas podemos mudar os pensamentos e, sem dúvida, muito mais facilmente, visto que eles dependem puramente de nós e visto que, para isso, não precisamos do sufrágio de ninguém. Os nomes foram dados às coisas para que sejamos compreendidos quando falamos uns com os outros. Ora, não seríamos compreendidos se seu significado fosse diferente para cada um e se eles não tivessem o mesmo sentido. Mas, como falamos conosco mesmo através de nossos pensamentos, nós lhes podemos dar a inteligência que melhor nos parecer, e não haverá sentido ou interpretação que eles recebam que não esteja de acordo conosco mesmos. Mas, seria bastante bizarro, para não dizer extravagante, querer tornar um sentido particular, que é contrário àquele de todos os povos, um sentido geral, ou querer destruir as Opiniões autorizadas pela multidão e fortalecidas pela reverência que a duração dá às coisas. Certamente, seríamos muito pouco razoáveis se parássemos sobre tão vãs considerações; e é bastante suficiente que o respeito da multidão tenha adquirido Veneração frente à mentira, sem que com isso ele o torne santo e inviolável. Aprendamos que a Verdade não é, de forma alguma, ultrapassada pela quantidade; que ela não se enfraquece com o tempo; e que, mesmo sendo só e abandonada, ela não é, porém, sem sua força e sua dignidade. Sentimo-nos mal por deixar o erro é porque o vemos tão universalmente seguido? E sentimos tantos escrúpulos em nos desenganar porque vemos que todo mundo se engana? Eu nunca ouvi dizer que um precipício seja menos perigoso só porque muita gente tenha caído nele. É

\footnotetext{
${ }^{38}$ No original latino, não há menção ao autor.

${ }^{39}$ A citação que, no original latino, aparecem em grego é traduzida para o latim assim: "Si bene prudens sis, omnibus fortunatus eris”; que pode ser traduzido por "se fores prudente, serás totalmente feliz”.
} 
uma extrema loucura imaginar que um abismo é seguro por causa da quantidade de pessoas que nele pereceram; uma chaga onde muitas mãos enfiam ferros se torna mais profunda e, consequentemente, mais mortal. Se se nos apresentassem um pedaço de carne que soubéssemos estar envenenado, quereríamos comê-lo por mais delicioso que parecesse antes e por mais sermões que lhe pregássemos para que ele se fizesse bom e saudável? Quer dizer, não temos que ter como exemplo o erro dos outros, mas temos que ter horror ao erro; é preciso que eles se nos sejam propostos para que fujamos deles, e não para segui-los. Será que eles parecem poder servir de regra, se não podem nem mesmo servir de desculpa? E se não podemos sequer pretender tê-los, na medida em que nós mesmos já erramos tanto? Será necessário que negligenciemos nossa salvação, baseados nesse mau fundamento, segundo o qual vemos a maior parte dos homens correr cegamente em direção à própria perda? Será preciso que nos afastemos tanto do bem porque eles se comportam tão mal? Do que nos serviria, eu vos pergunto, o grande número e a multidão de pecadores no último dia, se todos seremos julgados um a um, e se será apenas o nosso mérito que nos deverá justificar, e não a quantidade ou a multidão? Renunciemos, portanto, a estas Opiniões igualmente falsas e perniciosas; e não nos obstinando mais no erro, aprendamos que vale mais se salvar com poucos, do que se perder com muitos. Que os exemplos quase infinitos daqueles que caem no pecado não nos seduzam, não nos movam a pecar; e cessemos de nos gabar desta má persuasão, segundo a qual as faltas dos outros podem servir de desculpa para as nossas.

Se não ousamos contradizer a multidão, se não somos corajosos o suficiente para condenar aquilo que a multidão aprova, pelo menos que sejamos capazes de vencer nosso escrúpulo através deste pensamento; que se nos enganarmos será muito felizmente e que encontraremos nossa segurança em nosso erro; se não tomarmos como males as coisas que o vulgo depreciou e que se tornou matéria para o nosso temor; estando certos de que anda que, com efeito, sejam males, devemos mesmo assim duvidar, de forma que tiraremos maior vantagem se nos persuadirmos de que verdadeiramente não o são. Mas, então, como os deveis considerar? Vós me perguntaríeis. Diminuindo-os, sentindo-os apenas pela metade. Através disso, evitaremos os sofrimentos e as inquietudes de que eles são ordinariamente precedidos; eles só nos tocarão de leve; ao invés de atingir profundamente o nosso coração, eles só conseguirão tocá-lo de raspão, na superfície. Assim, só receberemos um ligeiro atentado; não os apressaremos e eles não chegarão tão cedo; como faz, ordinariamente, a apreensão que, não se contentando de aumentar sua força e redobrar sua violência, precipita sua vinda, tornando-os presentes para nós antes mesmo que eles o sejam e os faz existir quando eles ainda não são. Certamente, aquele que ela possui não será seguro em parte alguma; permanecendo como sempre é quando está consigo mesmo, trazendo em seu espírito a causa de todas as suas penas. Assim, a Opinião que temos sobre os males faz com que eles nos façam sofrer sem parar, e é muito em vão que pensamos em nos proteger de seus ataques fugindo. Não sabemos que seus ataques tem um longo alcance, que não há força ou velocidade igual à sua, que por mais habilidade e cuidado que tenhamos na fuga, não conseguiremos, que nos é absolutamente impossível nos defender deles? Pelo contrário, aquele que não se ocupa de seus ataques, não lhes dando atenção ou nenhuma vantagem sobre si, tem a consolação de vê-los partir tão logo os tenha visto chegar; e olhando-os de costas, ele consegue se confirmar nesta segurança que lhe diz que eles são mais assustadores de longe que de perto, e que tudo o que eles têm de mais terrível é seu rosto. Houve homens que se viram com um olho seco, sem emoção, sem sentir qualquer incômodo com o fato de lhes cortarem um membro; há os 
que ficam pasmos só de ver uma ferida ou o sangue de outra pessoa. Por mais que os povos tenham tido razão ao chamar de más as coisas pelas quais eles sentem horror - a pobreza, a dor, a ignomínia -, coisas que, porém, foram, para muitas pessoas, degraus para chegar à felicidade, e, para outras tantas pessoas, foram meios para praticar a Virtude, ser-nos-á extremamente útil suspender, quanto a isso, nossos sentimentos; imitando aquela seita de Filósofos que não acreditava em nada e que se dedicava a lançar dúvida sobre tudo ${ }^{40}$.

Que não pensemos, no entanto, que, dessa forma, queiramos algo mais do que uma segurança falsa e enganadora; cujo fundamento é apenas a imaginação e o capricho. Queremos torná-la sólida e real, estabelecê-la firmemente sobre a razão e sobre a verdade. Uma e outra nos ensinam que a multidão está no erro; que, governando-se apenas pela Opinião, que é cega e enganadora, ela não conseguirá ver para onde vai e será enganada. Nisso, não temos, de forma alguma, que contar os sufrágios, mas temos que pesá-los; é preciso examiná-los pelo valor, e não pela quantidade. O vulgo, em todos os tempos, foi julgado impertinente e muito iníquo. Não é nele que devemos acreditar; mas nos Sábios e esclarecidos, que, no alto e puro conhecimento que têm das coisas, sabem o justo preço de cada coisa; discernem claramente o bem do mal, e não se enganam em sua escolha. Eles nos exortam seriamente a renunciar a todas estas velhas Opiniões com as quais o vulgo nos infectou. É preciso nos desfazer, eles dizem, desta má complacência que nos colocar em perigo de perecer acreditando nos outros; é preciso também não nos obstinarmos num erro só porque ele é autorizado pelo tempo e pela crença comum dos povos; é preciso não se desculpar pelos próprios defeitos e não os defender em nada contra a autoridade soberana da Razão. Que cegueira é esta a nossa que nos priva do direito que a Razão nos dá de julgar as coisas, preferindo ser escravos do sentido dos outros que reinar sobre os nossos próprios sentidos, dando às coisas o preço que mais nos agradar; e fazendo-as depender de nós, ao invés de cair na infelicidade de depender absolutamente delas? Já aprendemos que, não estando a nossa disposição fazê-las mudar de Natureza, podemos, pelo menos, mudar os significados dos termos que usamos para exprimi-las; coloquemos em prática um meio igualmente fácil e salutar: estimemo-las tal como queremos e tomemos a liberdade de lhes dar o preço, da mesma forma que Adão teve a liberdade para dar a elas os nomes que têm. Eis a ação mais importante que poderia ocupar a nossa razão. Sem dúvida, ela nunca há de ter emprego mais nobre e digno do que esse. Cabe aqui, então, lançar os fundamentos de nossa felicidade e levantar o seu edifício até aos Céus, a fim de garantir-se contra os desígnios e as tempestades da Fortuna. Sejamos iguais e constantes na condução de uma tão grande obra; que a Razão e a Verdade nos sejam úteis nesse trabalho de medir e regrar; elejamos com luz as coisas que devem compor nossa alegria; e cuidemos com bastante atenção de não cari no inconveniente onde se encontram aqueles que construíam aquela imensa torre que pode ser chamada de a obra-prima imperfeita da temeridade dos primeiros homens ${ }^{41}$. A diversidade das línguas que foi o seu castigo os colocou numa tal desordem que, não se compreendendo mais, eles carregavam uma coisa achando que era outra, eles apresentavam madeira quando lhes era pedido pedra.

\footnotetext{
${ }^{40}$ No original latino, Nieremberg escreve: "Quare, esti mala essent, paupertas, ignominia, labor, quae plures bonos fecerunt; sententiam tuam, more Sceptico, suspedender, non inutile foret". Trata-se, portanto, da escola dos Céticos.

${ }^{41}$ No original latino, aparece: "Confusio intercipit vota, \& consilia tua, ac linguarum apud Babylonem conturbatio: aqua postulabatur, sed administrabatur later, attollitur rupes”. Trata-se da Torre de Babel.
} 
Assim, porque estamos em desacordo conosco e não nos escutamos mais, acontece algo que é contrário ao que esperávamos. Somos ainda menos satisfeitos, já que não obtemos nada que realize nossos desejos, e nunca os eventos respondem às nossas intenções. A Vontade fica descontente, tomando por bem o que é mal; ela deseja o bem com ardor e, conhecendo o desprezo do mal quando o obtém no lugar do bem, ela fica confusa e triste. Ela sente vergonha e dor por ter desejado aquilo que deveria temer; e de ter empregado sua busca por aquilo do que deveria fugir. Assim, caímos na miséria, seguindo as mesmas vias que havíamos crido nos levar à felicidade. Nossa cobiça cresce nesse erro; ela é incapaz de se satisfazer, porque, mesmo quando ela obtém um bem, ou ele deveria ser outro ou ele será menor do que ela havia esperado; ela nunca as possuirá inteiras, pois é sempre enganada. Esta desordem procede do fato que, ao invés de mudar os sentimentos que temos pelas coisas, queremos mudar as coisas mesmas. Queremos empreender o que é absolutamente impossível, e não o que é mais fácil. Ainda precisamos aprender que isso não está em nossas mãos; que só temos direito sobre nossos pensamentos e sobre nossos sentimentos; e que a Fortuna tem uma soberana potência sobre todo o resto. Mas, não admiremos o trabalho inútil que temos de procurar fora de nós o remédio para nossa miséria; saibamos, porém, que ele está em nossas mãos e que, sem sofrer em vão, como ordinariamente fazemos tentando mudar a natureza das coisas que chamamos más, só teremos que imaginar que elas não o são; não acreditando em nada na Opinião; reformando nossos sentimentos e justificando as coisas como sendo não culpadas das desordens que nós lhes imputamos.

\section{QUARTO TEMA}

\section{Os males vêm mais da opinião do que das coisas}

Desenganemo-nos inteiramente e descubramos, de fato, os males que recebemos da Opinião. É somente a ela que se devem os nossos males; eles não vêm, de forma alguma, das coisas. Somente ela é quem excita os temores e inquietudes que nos fazem sofrer; ela é a fatal causa dos problemas que se elevam em nossa alma; enquanto ela é ignorada, chegam-nos como que tumultos e sedições populares cujo autor não conhecemos muito bem. Temos em nós o inimigo que acreditamos estar fora de nós; somente a Opinião é que nos atormenta e nos faz a guerra; não tanto pelos males que ela nos suscita, mas por ela mesma; ela nos fere menos pela mão de outros que pelas nossas; ela é, sem dúvida, o maior de nossos males e, para dizer bem claramente, ela é nosso único mal. Estaremos nos enganando se acreditarmos que o mal se nos chega de outro lugar; não há nenhum mal que não venha dela e que não seja puramente obra sua. Eu vos pergunto, de onde pode vir o fato de que uma mesma terra parece, para um, o lugar de seu nascimento e, para outro, o lugar de seu exílio? E por que este último testemunha dor e aquele sente alegria? A Opinião é que faz esta diferença; ela persuade o último de que ele está em terra estrangeira, e não permite que ele escute a Razão que lhe diz que todos os lugares são a pátria de um homem de bem. Esta persuasão falsa e sem fundamento o enche de mal-estar. Ele só fica infeliz por que se imagina sendo. Nós vemos, sem sentir mal-estar e com o olho seco, a casa de um outro queimando e seu navio naufragando; não nos sentimos em nada tocados ou, se o somos, é apenas aparentemente; mas, se nos vemos em semelhante desgraça, ela nos aflige até ao último ponto da aflição e ficamos inconsoláveis. Uma vez mais: de onde pode vir isso, se não 
for da Opinião, que nos engana, persuadindo-nos de que as coisas são nossas? Se não tivéssemos esta crença, não teríamos nenhum sentimento de perda. Nossas infelicidades mesmas não seriam capazes de nos causar mais sofrimento do que aquele que sentimos pelas infelicidades dos outros. Ora, saibamos - e tenhamos isso por constante - que não há nada que possamos realmente chamar de nosso, além daquilo que está puramente em nós, além daquilo que depende de nossa Vontade; todo o resto pertence soberanamente à Fortuna. Que isso nos ensine que é preciso que tenhamos a mesma indiferença que temos pelas coisas que não nos dizem respeito também pelas coisas que são nossas; pois aquelas não nos são mais estrangeiras do que estas; e não temos menos razão em nos afligir por ver perecer as últimas mais do que por ver perecer as outras. Assim, portanto, é bem evidente que é somente a Opinião que causa nossa pena. Não seremos mais capazes de negar que somente nós é que somos culpados da desordem sobre a qual nos lamentamos. Nós jogamos essa culpa, em vão, sobre outros; e a causa está em nós. Somos os autores e os Operários de nossa própria ruína. Cessemos de nos fazer mal e cessaremos de recebê-lo; não façamos mais guerra contra nós e teremos uma paz eterna. O meio infalível para isso é seguir a Verdade e abraçar a Virtude; estando certos de que estaremos nos suscitando mal se nos afastarmos de uma e de outra; e que, para falar de forma correta, são somente as nossas faltas que nos causam sofrimento, seja porque nós nos fazemos algum mal, seja porque nós o imaginamos em coisas onde ele não está. Se não for mais razoável dizer que o mal ali está a partir do momento em que nos persuadimos disso, que, pelo menos, entendamos que nossa crença o estabelece ali o mal e empresta da coisa o ser e a força que o mal não tem por si mesmo. Que veneno poderoso é esse que pode haver na língua dos maledicentes para que sejamos atingidos primeiro no coração? Será que não há resolução suficiente em nosso espírito para que ele possa sustentar a espera? Não basta um trovão para que sejamos abatidos, permanecemos firmes diante de um relâmpago; mas basta uma simples palavra pronunciada por um invejoso, que tenha saído de sua boca, para nos jogar por terra. De onde pode vir o fato de que a Opinião - que perverte, como é seu costume, nosso entendimento -, nos faça acreditar que é uma extrema infelicidade ser atacados pela calúnia? Ou que aquilo que se diz sobre nós possa ser verdadeiro ou não? Se, porém, for mesmo verdadeiro, por que temos vergonha de ouvir falar daquilo que não tivemos vergonha de fazer? Se não é verdadeiro, não deveríamos nos consolar e nos alegrar com o testemunho que nossa consciência nos dá sobre nossa inocência? Certamente aquele que nos calunia receberá o mal que ele pensa nos estar fazendo; todas as flechas que ele nos lança cairão sobre ele; ele fere sem pensar nisso, e nós só somos feridos quando pensamos estar sendo feridos.

Não é estranho que sejamos muito mais pouco razoáveis no bom senso do que seríamos na loucura? É bastante conhecida a loucura daquele Ateniense que, acreditando que todos os navios do Porto de Pireu eram seus, agia como tal, controlando aqueles que partiam; fazendo votos de que retornassem e, quando voltavam, testemunhando enorme alegria por seu retorno ${ }^{42}$. Como esta sua crença passou e a razão lhe retornou inteiramente, ele avaliou nunca ter sentido alegria mais pura e sensível do que quando tinha aquela posse imaginária. Não tenho, aqui, nenhuma intenção de

\footnotetext{
42 No original latino, Nieremberg escreve: “Iniquius nostro insanimus iudicio, quam vecordia. Thrasyllus Aexoneus, profectus in Pyraeum, naves in album referebat proprium, quae subducebantur, suas aestimans: hac opinione, si quae in portu salvae venerant, immodica gestiebat laetitia”. O Porto de Pireu foi um importante porto da Grécia até o início da Era Cristã. Quanto ao personagem a que se refere, encontramos duas referências a ele, mas nenhum dado mais preciso: trata-se de Trasilo Assoneu, que é referido, em outra obra, como Trasilo, o Louco, mas não há dados sobre período que viveu e quem foi.
} 
determinar se somos ou não somos sábios. Mas, não tenho também nenhuma intenção de fingir que nossa extravagância é, muitas vezes, maior do que a dele. Choramos a perda de coisas que sabemos que não são nossas, mas que são dependentes inteiramente da Fortuna. Somos artesãos tão engenhosos de nossos próprios males, que nem mesmo o mais cruel e impiedoso de nossos inimigos seria incapaz de desejar um mal maior do que aquele que nos suscitamos a nós mesmos. Não perdemos nada quando não perdemos as coisas que estão dentro de nós - as únicas que podemos realmente chamar de nossas; e no entanto nós nos afligimos muito mais quando perdemos as coisas que não nos pertencem, a ponto de nada nos consolar. Da mesma forma que há homens que tremem simplesmente por ver certos objetos de quem não poderiam receber mal algum, e que há homens para os quais um pequeno ruído, como o de dois pedaços de ferro um contra o outro, ou de dentes esfregando, causa irritação e pena, nós nos atormentamos sem saber o motivo, concebemos males e temores estando em perfeita segurança. Acontece conosco o mesmo que acontece a alguém que olha de cima de um lugar bastante alto e que, incomodado por si mesmo, acaba caindo sem que ninguém o tenha empurrado. Caímos na dor, tendo sido empurrados apenas pela Opinião. Visto que, portanto, é constante o fato de que todos os nossos problemas provêm dela e que é somente ela que nos torna miseráveis, o remédio é fácil e a cura é certa: basta conhecer a causa do $\mathrm{mal}^{43}$. E se o entendimento, corrompido como está pela Opinião, conserva luz suficiente para julgar de onde procede a doença, e tem vigor suficiente para se defender; se o entendimento, fragilizado como se encontra, pode se livrar daquilo que lhe causa aflição; imaginemos do que ele não será capaz quando agir com toda a sua força e quando estiver plenamente assistido pela razão. Se, estando doente, ele pode curar-se a si mesmo; se ele pode expulsar a dor, está fora de dúvida que, estando são, ele poderá não admiti-la sequer de maneira muito melhor ainda. Às vezes, acontece que, encontrando-se em meio a uma grande e repentina infelicidade vinda de fora de si, que o entrega às forças da Opinião, e faz como que elas lhe imprimam falsas imagens, ele evita os transes e as amarguras que ela atrai em seguida, ele se garante contra os males onde caem aqueles a quem ela engana e que se deixam preocupar. Assim, os empregados de Pompeu, que o viram servindo-se de Vítima para a crueldade de seus inimigos, o viram mantendo os olhos secos e não derramaram uma lágrima sequer, até que, chegando a Tiro, onde não tinham mais nada a temer e se encontravam em perfeita segurança, eles se abandonaram à dor e ficaram extremamente afligidos. O objeto presente da morte que os ameaçava, e o violento desejo de fuga que os possuía igualmente, transportou seus espíritos para fora de sua sede natural e como que fechou todos os caminhos para a Opinião. Deixo de lado o fato de que o tempo é um excelente remédio contra a dor; já que a experiência nos ensina que não há dor tão forte que nos possa, de um só golpe, nos jogar no chão e que não enfraqueça como tempo; assim como, além do mais, não há nenhuma dor que não diminua quanto menos acreditemos ou confiemos na autoridade da Opinião.

\section{PRIMEIRO ENSINAMENTO}

\footnotetext{
${ }^{43}$ No original latino, Nieremberg, neste trecho, cita um pensador de nome Aríston: “Optime Ariston dixit inter insaniam publicam \& hanc, quae medicis traditur, nihil interest, nisi quod haec morbo laborat”. Não encontramos, porém, dado que precise de forma mais exata a quem se refere. Sabemos que há vários personagens na antiguidade com este nome: há um rei - Aríston de Esparta (séc. VI a.C.); há o pai de Platão - Aríston de Atenas (séc. V a.C.); há um filósofo peripatético - Aríston de Queos (séc. III a.C.); há um estóico - Aríston de Quios (séc. III a.C.); há outro peripatético - Aríston de Alexandria (séc. I d.C.) etc..
} 


\section{O remédio contra a opinião é conhecê-la}

Mas, há um meio raro e infalível de evitar os inconvenientes nos quais a Opinião nos faz cair. Temos um soberano remédio contra os males que ela nos suscita. É preciso sempre relembrarmo-nos de que ela é infiel e enganadora; que, semelhante aos quadros que nascem do capricho dos pintores, ela não representa nada de verdadeiro ${ }^{44}$; é preciso sempre considerá-la como uma operária do erro e da mentira; desconfiar dela incessantemente, e nunca ter fé nela. A morte violentou nossos filhos, perdemos nossos bens, fomos decepcionados em nossas pretensões, o mundo nos recusa sua estima; numa palavra, vemos uma tempestade de infelicidade pronta para cair sobre nossa cabeça; mas não nos assustemos, esperemos com os pés firmes e pensemos: "Eu me engano ao acreditar que sejam as coisas a me fazer sofrer; somente a minha Opinião é responsável por isso; este é o erro onde me encontro quando as tomo como males em si mesmas; nisso, não há nada capaz de me afligir; o mal que eu lhes imputo vem inteiramente de mim, sou sozinho o autor da desordem que acuso como sendo causado por elas. Tenho horror à pobreza; mas é porque eu a pinto e a represento horrível; e figurando-a assim para mim mesmo, sou eu mesmo o responsável pelo medo que sinto; eu é que dou a ela, através da minha Opinião, este rosto que me assusta; com efeito, ela não o tem por si mesma; ela não é nem aflitiva nem assustadora, mas, ao contrário, é agradável e traz alegria. Sem me apoiar aqui sobre as provas que o Cristianismo poderia me dar, segundo as quais ela tem encantos e graças que provocam em nós muito mais do que desejo de fugir, mas desejos de abraçá-la voluntariamente e de deixar todas as coisas para segui-la, empregarei os exemplos daqueles que, não tendo sido em nada iluminados do alto, e só tendo as luzes e ajudas naturais, a amaram por si mesma, e só tiveram como objeto a satisfação que a acompanha. Penso naquele bom velho da Arcádia que, nunca tendo saído dos limites de um pequeno poço, de onde ele tirava apenas aquilo de que tinha necessidade para se alimentar, saboreava contentamentos que aqueles que estão cheios de riquezas não conhecem; e foi julgado pelo Oráculo como mais feliz do que Giges, um dos mais poderosos Príncipes do mundo. Penso também naquele Ateniense cuja felicidade foi testemunhada pelo primeiro dos Sábios da Grécia; não esquecerei também aquele Filósofo cuja feliz miséria tentou o grande Alexandre e causou inveja à opulência e ao luxo. Tantos outros cuja sabedoria é ainda venerada por nós e que encontraram delícias na pobreza - Crates, Aristides, Demónax são os nomes que me vieram à cabeça ${ }^{45}$. Penso também no famoso Epaminondas, para quem ela não

\footnotetext{
44 No original latino, Nieremberg apresenta esta mesma argumentação assim: "Non leve adversus hanc momemtnum putes, cognosci: si tibi ubique renunties: Pergula pictorum, veri nihil, omnia falsa”.

${ }^{45}$ No original latino, Nieremberg se refere a vários personagens, além dos citados pelo tradutor: “Horreo paupertatem, quia horridam puto; \& dum puto, horrorem mihi incutio: at laeta Aglao fuit; felix Tello, affectata Diogeni, quaesita Crateti, pertinax Demonaci, gloriosa Epaminondae, studiosa Horatio, iusta Aristidi, secura cunctis”. O que poderia ser assim traduzido: “A pobreza me horroriza, porque a penso horrível: mas enquanto a penso, eu mesmo me causo o horror; mas ela foi alegre para Aglao, feliz em Tello, fingida por Diógenes, buscada por Crato, vivida com pertinácia por Demónax, gloriosa para Epaminondas, amada por Horácio, justa em Aristides, segura para todos”. Assim, os personagens referidos por Nieremberg são: Aglao, de quem não encontramos nenhuma referência; Tello, de quem também não encontramos referências precisas; Diógenes de Sínope (c. 404 a.C.-c. 323 a.C.), filósofo da Escola Cínica, que, segundo a tradição, perambulava pelas ruas e vivia dentro de um barril; Crates de Tebas (c. 365 a.C.-c. 285 a.C.), filósofo também da Escola Cínica e mestre de Zenão de Cítio e discípulo de Diógenes de Sínope, sacrificou toda a sua fortuna em nome dos princípios de sua escola de pensamento; Demónax (séc. II d.C.), filósofo da mesma Escola Cínica, e que, segundo se conta, viveu ainda mais austeramente que Diógenes de Sínope; Epaminondas (c. 418 a.C.-362 a.C.), general e político
} 
trouxe menos glórias do que suas façanhas, e que ele não quis trocar nem por toda a riqueza do mundo. Sobre isso, farei uma justa reflexão: perdi a razão quando temi aquilo que tantos homens tão excelentes amaram, quando tomei como um mal aquilo que tiveram como um bem. Assim, descobrirei a injustiça da Opinião, quando me persuade do contrário; e vendo, com isso, como é perigoso escutá-la, rejeitarei seus conselhos, como sendo cheios de imposturas e de traições. Fui atacado pela calúnia? Ela não me fere, eu direi para mim mesmo, mais do que o tanto que eu imagino; ela não consegue me pegar, a não ser se minha Opinião assim o crê. Será que serei louco de me afligir? É uma palavra e não uma pedra que sai da boca do caluniador; não é um raio, é uma palavra que não tem força nenhuma por si mesma. Sem dificuldade, o espírito é mais firme do que o corpo; sendo assim, que vergonha para o corpo que cai por terra quando o o espírito, diante da mesma calúnia, permanece de pé! Que vergonha que o mais forte seja abatido! Como pôde ser feita a ferida no meu coração se nada foi feito ao meu corpo? De onde pode ter vindo a flecha que atingiu primeiro um sem ter atingido o outro? Visto não haver nenhuma marca exterior, sem dúvida que ela veio de dentro; é um golpe da minha Opinião; foi ela quem me feriu e não o caluniador. Pois bem, ele me cobrirá de injúrias, ele vomitará todo o seu fel sobre mim; eu não revidarei, eu não direi uma só palavra. E, diferentemente do povo que crê ser uma desonra ceder em ocasiões semelhantes, eu acreditarei ter tido uma grande vantagem sobre ele, assumindo a postura mais forte e mais honesta. Eu manterei a boca fechada e em silêncio; ele ficará cansado de tanto falar e eu não me cansarei de calar. E, depois de tudo, o que quer que ele faça e por maior que seja o excesso de sua insolência contra mim, o que me acontecerá? Eu não apenas não perderei nem mesmo um fio de cabelo, não sentirei nem mesmo o dedo dolorido. Ao contrário, serei eu a causar-lhe problemas, na medida em que é certo que, se eu não me aferroo, o aferroarei sensivelmente; ele ficará fora de si, ao me ver sem emoção; eu o colocarei em desespero, se não ficar em cólera. Desta maneira, pararei o transbordamento de suas palavras, acalmarei a tempestade que ele tiver suscitado; enquanto que, seu eu o contestasse, eu o tornaria ainda mais violento; assim como só é possível reter um vento impetuoso que passa por duas janelas fechando uma - após o que ele para inteiramente, ele não sopra mais de um lado a outro -, também será fechando minha boca que pararei este turbilhão que sai da sua. Se esta verdade, cuja experiência não me permite duvidar, precisa ser confirmada por exemplos, trarei na memória Dionísio e Catão que triunfaram, dessa maneira, sobre a malícia de um maledicente e, dessa mesma maneira, fizeram crescer bastante a reputação de sua sabedoria"46. Certamente, isso é um combate, onde a vitória não se ganha menos por resistência que por fuga, e onde as pessoas de bem entram com tanta desvantagem quanto as pessoas malvadas que costumam, nisso, ser mais fortes, na medida em que estão continuamente praticando o mal e não têm menos facilidade em dizer do que em fazer. Enquanto que, os demais, nisso, têm uma repugnância natural e,

grego, responsável por levar Tebas a se tornar uma potência hegemônica na Grécia, substituindo Esparta, é bastante elogiado pelos seus contemporâneos pelo fato de desdenhar toda riqueza material, tendo vivido em grande simplicidade e asceticamente; Quinto Horácio Flaco (65 a.C.-8 a.C.), poeta lírico e filósofo romano, que tinha uma forma de pensamento muito semelhante a dos Epicuristas, sobretudo quanto ao que concerne à brevidade da vida; e Aristides de Atenas (c. 535 a.C.-c. 468 a.C.), estadista e estrategista ateniense cognominado o Justo, conta-se que morreu em extrema pobreza, não tendo nem mesmo o suficiente para o próprio funeral.

46 Ao que tudo indica, trata-se de Dion de Siracusa ou Dionísio I (408 a.C.-354 a.C.) que foi um admirador e aluno de Platão, e tirano de Siracusa; e de Marco Pórcio Catão (234 a.C.-149 a.C.), que foi um político romano, tendo ocupado os cargos de Cônsul e de Censor. 
consequentemente, têm extrema dificuldade, na medida em que são sempre novatos e desajeitados, por assim dizer, e que lhes falta, nisso, o exercício e a vontade.

“Terei eu medo da morte? Sem dúvida, nisso tenho menos fundamento razoável que no resto. Eu fantasio que ela seja malvada, mas me engano, pois ela não o é; isso é fruto apenas da persuasão que me faço. Se me desfaço desse engano, eu a acharei não apenas suportável, como também doce. É pura aparência que tenhamos por mal aquilo que os miseráveis desejam, aquilo que é salutar mesmo aos que são felizes, aquilo que faz com que os primeiros parem de sofrer e os outros de agir mal! Será certamente uma injúria ter este sentimento por ela; é como que faltar à razão não tomar por um bem aquilo que encerra inteiramente nossos males. E, necessariamente, é preciso confessar ou que ela não tem mal algum ou, ao menos, que não é possível chamar como mal algo que nos livra do mal. Por que eu ficaria incomodado com ver acabar aquilo que me incomoda ver durando? O que diríamos do Piloto que se lamentasse de ter chegado ao Porto, tão impacientemente desejado durante a tempestade? Que loucura seria a minha recusar o socorro daquele que vem me descarregar de um fardo cujo peso me destruiria? Quando eu detenho a morte, eu detenho aquilo que eu desejo; eu firo meus próprios sentidos; não estarei de acordo comigo mesmo. Mas, é a maneira de morrer, e não a morte, que me causa apreensão; eu temo que ela seja cheia de violência e de infâmia. Certamente, quem não quer morrer, sempre morre de morte violenta, visto que só se pode fazer por força aquilo que não é de seu agrado. Mas, não há morte inconveniente para quem bem viveu; se minha vida é irrepreensível, minha morte será sem ignomínia. Ficaria irritado como o fato de ela ter sido repentina; não gostaria que ela me tomasse em plena saúde? Mas, será possível que eu não seria capaz de entender, a partir disso, que a doença é uma boa coisa, visto que eu desejo a morte? Será que não entendo que, se ela é ruim - e que a morte o seja também - eu serei certamente muito extravagante de não desejar dois males? Sendo que o mais certo e fácil seria evitar o primeiro pelo segundo. Mas, eu tenho medo de que ela venha muito cedo, e que ela me faça perder um longo tempo que ainda tenho para viver. Desde quando eu posso pensar em lhe prescrever um tempo que ela não ousa antecipar? Além do fato de não se poder criar convenções com ela; sem dúvida, é preciso entender que, por mais adiantada que ela seja, ela é sempre tardia, visto que ela sempre pode chegar a qualquer momento. Se há alguma morte que vem muito cedo, é somente a morte dos malvados, para quem ela previne da necessidade de se arrependerem e que, no entanto, nunca pensam nela; mas, como as pessoas de bem sempre estão preparadas, como ela pensam nisso incessantemente, elas nunca serão surpreendidas. Eis que é sutil, alguém me dirá; mas, nem por isso, é menos verdadeiro”. Escutemos, a este respeito, estas belas palavras de um grande Filósofo ${ }^{47}$. Da mesma forma como sentimos prazer em nos exercitar na disputa e de tratar de questões sutis, que nos aguçam o espírito e nos formam no hábito de nos defendermos mais facilmente contra as finezas e as cavilações dos Sofistas, devemos, da mesma forma, nos exercitarmos na resolução das questões e das dúvidas que nossa imaginação nos propõe; e temos também que nos aguerrir contra ela, a fim de

\footnotetext{
${ }^{47}$ É interessante notar que todo este trecho entre aspas não faz parte da argumentação de Nieremberg, mas foi acrescentada pelo tradutor, Louys Videl. Evidentemente, não se trata de um acréscimo que extrapola a linha de argumentação do autor, mas apenas, como o próprio tradutor afirmou na introdução que escreveu, enriquece a proposta de Nieremberg ao apresentar essa espécie de "diálogo interno". Quanto ao filósofo sobre o qual o texto refere, no texto latino, o autor escreve: "Subtilia ista, dices: an \& vera? Egregium Epicteti monitum: Quemadmodum ad quaestiones \& sophismata nos exercemus: ita quotidie contra phantasiam exerceri nos convenit; ab illa proponuntur nobis quaestiones”. Trata-se, portanto, de Epícteto (55-135).
} 
não nos deixarmos nunca surpreender e nunca deixar que ela tenha alguma vantagem sobre a nossa razão. E mesmo que, segundo um outro Filósofo, tenhamos nisso três grandes adversários que são extremamente absolutos - a Opinião, a Paixão e os Costume -, é certo que, como o primeiro é o mais poderoso de todos, visto ser aquele que estabelece o reino e a dominação sobre os outros dois, será, para nós, suficiente que lhe resistamos e tiremos o jugo que tem sobre nós, para não ter nada a temer ${ }^{48}$. Sem dúvida, sendo que estaremos livres da Opinião, não teremos nenhuma dificuldade para nos livrarmos da tirania da paixão e do costume.

Portanto, é preciso que dediquemos todos os nossos cuidados no sentido de nos libertarmos dessa servidão; é preciso fazer todos os esforços possíveis para arruinar o Império da Opinião. Ora, a mais segura via para chegar a isso é, sem dúvida, examinála; para destrui-la, é suficiente entrar numa séria consideração sobre ela. Da mesma forma que, quando sonhamos, sofremos; quando imaginamos cair num precipício, ou que um inimigo coloca a espada em nosso pescoço, ou que estamos sendo perseguidos por algum animal selvagem, só conseguimos sair do sofrimento que essa imaginação nos causa, quando nos recolocamos no verdadeiro estado em que estamos; e dizemos, mesmo sonhando, que estamos sonhando; que aquilo que imaginamos não existe; que estamos em nossa cama e que não estamos no perigo que nossa imaginação perdida nos fez crer estar. Assim, quando nos parecer que tenhamos caído numa profunda desgraça, e que um poderoso problema nos devora, recolhamo-nos em nós mesmos e digamos com coragem que tudo não passa de uma ilusão que nos incomoda e que não é uma verdade; que aquilo que acreditamos ser, com efeito, está apenas em nossa imaginação; que é apenas uma máscara que nos assusta, ou um fantasma que nos alarma. Desta maneira, conseguiremos vencer mesmo nas dores mais obstinadas; esclareceremos nossas mais negras tristezas; elas desaparecerão diante de nós, como as nuvens que desaparecem diante do Sol. Através disso, dissiparemos todas as quimeras da Opinião; tornaremos seus artifícios vãos; e vendo que é somente ela quem nos faz mal, conseguiremos rir mesmo dos maiores horrores; caçoaremos da fraqueza onde tivermos caído em nossas lamentações. Será que não sentimos vergonha de ver que, se um copo ou outro recipiente semelhante vem a se quebrar e se fazer em pedaços, nós ficamos num estado de tal cólera, que se chega mesmo a parecer que tudo aquilo que possuímos de bens e de fortuna tenha caído ao mesmo tempo, e que, nisso, está a queda e a ruína mesma de nossa Razão? Um pedaço de cristal será o recife que a fará naufragar? E seremos tão censuráveis por ter um espírito tão pouco firme, tão pouco sólido, a ponto de ser comparável à fragilidade de um cristal? Eu vos pergunto: por que tanto barulho? $\mathrm{O}$ que pretendemos com todas as ameaças e injúrias que lançamos contra nossos criados? A este respeito, é preciso que apliquemos aquilo que Epícteto nos diz a respeito de tudo aquilo que acontece no mundo ${ }^{49}$ : que é preciso nos lembrarmos de que ele é feito da mesma maneira que essas coisas. Lembremo-nos de que não há nada de mais frágil do que o vidro; que sua natureza é quebrável; que este é o seu destino, por assim dizer. Certamente que os menores acidentes - pois mesmos eles acabam nos fazendo mal - são capazes de nos fazer muito, sobretudo quando é a Opinião que os provoca, sobretudo quando estamos esquentados pela cólera. Nesse ponto, podemos nos lembrar de um exemplo tirado de uma aventura acontecida com o conhecido Galeno, que

\footnotetext{
${ }^{48}$ No original latino, Nieremberg afirma: "Tametsi tria tingendarum rerum pigmenta, opinionem, cosuetudinem, affectum, Pyrrho censuerit”. Trata-se, portanto de Pirro de Élis (c. 360 a.C.-c. 270 a.C.), filósofo grego considerado o primeiro pensador cético.

${ }^{49}$ Trata-se de Epícteto (55-135).
} 
justifica como ele não era menos Médico do espírito que do corpo, e que sua suficiência se estendia também para a cura das doenças do primeiro, assim como para a cura das doenças do corpo $^{50}$. Voltando, um dia, de Roma a Pérgamo, com um Gortinense ${ }^{51}$, personagem bastante recomendado por causa de suas muitas qualidades, mas que as apagava todas devido à sua extrema prontidão para a cólera ${ }^{52}$; este cidadão embarcou uma parte de seus instrumentos no Porto de Corinto, para levá-los a Atenas; e tendo mantido o restante, alugou um carro e tomou seu caminho, por terra, junto com Galeno. Alguns dias depois, tendo pedido certos instrumentos a dois de seus Escravos, os quais ele queria ver naquele instante, e os escravos, não conseguindo se lembrar, tão prontamente, onde eles estavam, e sua memória não estando igual à impaciência do cidadão de Gortina, ele ficou de tal forma sentido, e a Opinião que ele concebeu de que havia perdido aquele instrumento o encheu de tal forma de tanto furor que, os golpeando com uma espada, ele os encheu de tão grandes feridas que eles perderam muito sangue. Este espetáculo, fazendo-o voltar a si, e a razão retomando o lugar que a cólera lhe havia arrancado, fez com que ele sentisse tanto arrependimento e vergonha de ter se comportado daquela forma, que ele abandonou a companhia na qual estava e foi sozinho para Mégara, onde, reencontrando Galeno, que chegou ao mesmo tempo que ele, e lhe contando com dor aquilo que havia acontecido, ele lhe pediu que entrasse no quarto onde, colocando-se nu, apresentou-lhe uma correia e o conjurou a castigá-lo rigorosamente, dizendo que, por ter se tornado escravo de sua cólera, ele merecia, a bom direito, ser tratado como os Escravos, e sofrer a pena ligada à baixeza de sua condição. Mas, por mais instante que ele fosse, Galeno se recusou todo o tempo; finalmente, o Gortinense, tendo se jogado a seus pés, e tendo empregado novas conjurações acompanhadas de lágrimas, ele lhe prometeu satisfazê-lo, desde que, de sua parte, cumprisse uma condição à qual ele o queria obrigar, que era escutá-lo tranquilamente e sem interrupções sobre algo importante que ele queria dizer. O Gortinense, tendo ficado de acordo, escutou um longo e sério discurso sobre o fato de não estar nisso o meio para reprimir sua cólera, sobre o fato de que tudo o que era necessário era empregar a Razão, que é o soberano remédio contra todas as doenças do espírito. Esta verdade imprimiu-se tão fundo no Gortinense e produziu um efeito tão bom, que ele, a partir de então, adquiriu uma moderação evidente e nunca mais caiu no excesso no qual, tão frequentemente, ele costumava se lançar. Ele se curou das fraquezas e das ilusões da Opinião. Certamente, ela é tão perigosa, e as desordens que ela causa são tão estranhas, que eu conheci uma mulher que acreditava ter perdido tudo aquilo que ela possuía de mais precioso, quando perdeu um cãozinho que era seu único amor; passou dois dias inteiros chorando e, durante esse tempo, não comeu nem viu a luz do dia. Quer dizer, seus olhos estavam nas trevas da mesma forma que sua razão e que, somente com a luz do Entendimento, ela quis ainda perder a outra ${ }^{53}$.

\footnotetext{
50 Trata-se de Cláudio Galeno (c. 131-c. 200).

${ }^{51}$ Cidadão de Gortina, na ilha de Creta.

52 No original latino, Nieremberg é mais detalhista na descrição: “Is comitem itineris Roma rediens habuit Gortynensem civem, pluribus quidem rebus non contemnendum, simplicem virum moribus, officiosum amicis, frugi secum, liberalem ad sumptus; sed cuius omnes istas dotes corrumpebat praecipiti phantasia furor"; que poderia ser traduzido assim: "No seu retorno de Roma, teve como companheiro um Cidadão de Gortina, verdadeiramente notável por muitas qualidades, homem de costumes simples, respeitoso com os amigos, moderado e, ao mesmo tempo, liberal no gastar; mas todas estes dotes eram corrompidos pelo furor de sua fantasia impetuosa”.

53 No texto latino, Nieremberg é mais claro: "Unicum morum remedium, ratio est. Novi \& ipse biduo abstinentem cibo omni, \& luce foeminam, solum tenebris \& lacrymis incumbentem, ob interitum catuli: pari
} 
Se a razão não nos comove o suficiente para que a abracemos, se nós não ficamos suficientemente seguros com ela e não temos crença suficiente para fazer dela nossa guia; que, pelo menos, nós consideremos o extremo perigo que há no seguir a Opinião e que, ao menos, a incerteza evidente desta última nos leve a confiar na invariável firmeza da outra. Que nos lembremos de que a Opinião é um sonho perigoso de um homem que vela; e que ela nos causa a mesma pena, pelas impressões que ela nos dá, que os nossos pesadelos nos causam, através das ilusões e das quimeras que nos são colocadas dentro da imaginação. Ela, certamente, sempre foi criticada entre aqueles que se dedicaram ao estudo da sabedoria. Mas, aquele entre estes que a condenou mais altamente e que obteve o mais glorioso triunfo, foi Pirro, que, não se contentando apenas em acreditar que tudo aquilo que ela nos debita como mal não o é, e que não há mal algum nas coisas, além daquele que se imagina, justificou esta verdade através de si mesmo, tendo visto a si mesmo, com uma constância miraculosa, com os membros cortados e queimados, e não mudando em nada o rosto, não chegando mesmo a franzir o cenho. Que isso nos ensine o quão nos será de expediente acreditar que não há males; visto que, mesmo se os houver, não seremos capazes de nos enganar. E, pelo contrário, disso tiraremos uma vantagem considerável. Através disso, deceparemos a maior parte de nossa miséria, decepando a apreensão que a precede; porque, o que poderia temer aquele que não imagina nada que possa lhe causar sofrimento? Certamente, se estivéssemos livres do problema que os males que virão nos causam, seríamos isentos daquilo que eles têm de mais sensível e desagradável. A experiência comum verifica que sofremos muito menos, sem dúvida, no senti-los do que no esperá-los. Há homens rústicos e ávidos da boa carne, para quem a simples imaginação de uma carne deliciosa imprime de tal forma neles o gosto que, para dizer com o povo, a água lhes vem à boca. As crianças e os doentes rejeitam um remédio antes de lhe haverem sentido o sabor; eles têm como que a amargura do remédio em sua língua, quando o remédio ainda está em sua mão. De onde pode vir isso, eu vos pergunto? Seguramente, isso não é devido nem à carne nem ao remédio; mas se deve puramente à Opinião. É ela que causa em nós esta aversão ou este apetite; é ela que faz com que tenhamos esses falsos sentimentos acerca das coisas. Por isso, é preciso que nos resolvamos seriamente a nos desfazer da Opinião, é preciso que nos curemos dessa persuasão que ela tem acerca do que é mal. E certamente, quando ele de fato existir e ele vier a nos enganar, pensemos que isso será uma grande felicidade, pois, através disso, nós os diminuiremos bastante e o descontentamento que por ventura vier só será suficiente para nos tirar das inquietudes e da pena.

\section{SEGUNDO ENSINAMENTO}

\section{O saudável uso da opinião e do entendimento}

Até aqui, vimos as desordens da Opinião; conhecemos seus enganos. Vejamos, de agora em diante, o seu bom uso. Assim como ela é maléfica e perigosa, ela pode ser

caligine corpus damnavit mens caeca: carvit ratione recta, efficaci opinionis fármaco”. Que poderia ser assim traduzido: "O único remédio para os costumes é a razão. Eu mesmo conheci uma mulher que, por causa da morte de seu cãozinho, se absteve, por dois dias, da comida, fechada num quarto escuro, sem deixar entrar a mínima luz, desfazendo-se continuamente em lágrimas: a mente cega condenou a igual prisão o corpo: ficou privada da reta razão, fármaco eficaz contra a opinião”. É interessante observar que há uma diferença - que já se fez notar em outros momentos do texto e sobre a qual teremos a oportunidade de dedicar uma explicação mais aprofundada - entre mente e razão, entre entendimento e razão. Diferença que não é estranha, nesse contexto histórico-cultural. 
útil e proveitosa. Assim como ela causa mal, sem dúvida ela pode causar o bem. Ela, verdadeiramente, atrapalha nossa alegria; mas também ela alivia e encanta nossos problemas; ela nos fere, mas ela pode nos curar; semelhante a esses insetos que trazem em si o remédio para curar a picada que eles dão, que são, ao mesmo tempo, antídoto e veneno, e que nos socorrem contra eles mesmos. Há muita arte no tornar inocentes as coisas nocivas; mas há ainda mais arte no torná-las salutares; e trata-se de excelente ciência conseguir converter o mal em bem. Uma mesma coisa serve ou prejudica, segundo seus diversos usos; tornamo-la boa ou má segundo o uso no qual a aplicamos. Assim como um hábil Escudeiro não diminui a força e a coragem de um jovem cavalo, nem condena sua vivacidade e suas asperezas, mas as regra e as ajusta para que sejam úteis, da mesma forma esta potência que forma em nós as imagens das coisas, e através das quais nós as apreendemos, estando desordenada e errada, destrói inteiramente nossa alegria $^{54}$; é certo que ela pode nos ajudar bastante no estabelecimento da alegria, desde que seja instruída e treinada; ela pode produzir a paz e a tranquilidade do espírito. Aqueles que não acreditaram naqueles que a acusaram do contrário, e imaginaram que ela pudesse fazer crescer nossa miséria por suas invenções, tornando mais difíceis e duras nossas dores e calamidades, não consideraram que ela é capaz também de os diminuir; e que, estando pura e inocente - como nós queremos deixá-la - ela pode reparar os maiores ultrajes que recebermos da Fortuna. Aqui, é preciso que nos lembremos de que há duas ordens de coisas: uma que é aquela das coisas que são mutáveis e passageiras e não dependem em nada de nós; outra que é aquela das coisas que são firmes e permanentes, e que estão em nosso poder. Ora, visto que é puramente das primeiras que procedem nossas dificuldades, que são elas que causam nossos sofrimentos e penas, seja porque desejamos umas ou tomamos outras nas mãos, elas nos tornam incessantemente infelizes, elas nos causam sofrimento sem parar, seja pelo desejo, que pelo temor. Não seremos capazes de resistir a elas por nós mesmos; faltanos coragem e força para nos defendermos de seus ataques. É preciso que sejamos prevenidos de toda e qualquer impressão favorável que nos assegure e nos fortifique no combate que devemos ter contra elas; que nós as fantasiemos e escondamos sob uma máscara que não seja semelhante a elas mesmas, desfigurando-as até ao ponto de não encontrarmos mais nada nelas que nos atraia; e que seja capaz, pelo contrário, de maquiar as outras, escondendo aquilo que nos assusta. É preciso que a Razão nos conceda esse bom ofício, e que ela nos dê esta impressão. E seguramente ela no-lo fará, desde que a escutemos falando-nos assim: "Guardai-vos de julgar aquilo que sofreis, porque são os vossos sentidos que vos dizem as palavras para o julgamento, e eles são enganadores e errados; é nisso que seu testemunho é menos admissível. Por que vos lamentais e vos atormentais tanto como fazeis? Aprendei que por mais forte que seja a dor, a Paciência é ainda mais forte; e que não há mal algum que possa ser maior do que a glória de o sofrer com constância. Se o mal passa rápido, a glória dura bastante; se o mal durar muito, a glória é eterna. Sofre-se com facilidade e sem maiores dificuldades quando se sofre voluntariamente. É nisso que há menos sofrimento e muita honra; a pena é leve, mas a glória não. É preciso aceitar os pequenos males, porque eles vos instruirão para a paciência; é preciso aceitar os grandes, porque eles vos serão gloriosos. E o que sabeis vós se eles ainda não são a causa e o instrumento de algum bem que deve vos chegar? O que sabeis vós se a infelicidade que vos atingiu não vos está preservando de uma infelicidade ainda maior? Se não é apenas um refúgio que a má sorte vos está abrindo contra ela mesma? O quê? Vós não vos lembrais de que sois? Não vos lembrais

\footnotetext{
${ }^{54}$ Nieremberg está falando da Fantasia ou da potência Imaginativa.
} 
de vossa condição enferma? Pensai nisso seriamente, oponde bem ao vosso mal; oponde a lembrança de vossa fragilidade natural ao rigor das obrigações que ela vos impôs. Pensai no fato de que não sois Deuses, mas que sois homens; que não vos é menos próprio sofrer que viver; e servi-vos deste pensamento como quem se serve de um remédio soberano contra toda sorte de dores. Temperai a amargura de vossos males com a satisfação que tirais do conhecimento de vós mesmos. Mas, tudo isso é incapaz de fazer cessar vossas lamentações. Vós somente sois capazes de colocar em vosso espírito que aquilo que vos aflige é um mal. Será que vos esqueceis de que todas as coisas procedem de Deus? Que sendo, como Ele é, soberanamente bom, dEle nada pode vir que seja mau; que os efeitos não podem ser de outra natureza que suas causas; e que ordinariamente os riachos têm a mesma qualidade de sua fonte? Aprouve a Deus que este acidente vos tenha atingido; foi Ele que o ordenou, Ele o quis; será que vos deveis preferir vossa vontade à Sua? Será que vós deveis estimar mais vosso simples sentido à Sua suprema sabedoria? Não obstante isso, vós ainda murmurais e permaneceis em vosso endurecimento. Pois bem, atormentai-vos o tanto que quiserdes; abandonai-vos à cólera; segui a impetuosidade de vossa paixão; numa palavra, fazei tudo aquilo que vós imaginais ser capaz de levar para longe a vossa dor; tudo o que conseguireis é provar esta verdade: a impaciência azeda os males e os aumenta; pensar em curá-los através disso é cair na extravagância daquele que quis apagar o fogo com óleo, com algo que o acende ainda mais. Mas, meu mal é tão inconveniente, vós dizeis, que eu não consigo sofrê-lo; se ele fosse menor, eu conseguiria me consolar de alguma forma; se ele me fizesse sofrer apenas mediocremente, eu seria capaz de ter paciência. Quem já ouviu dizer que onde o inimigo faz mais esforços é onde ele falha menos na resistência? E não é verdade que quando a dor vos pressiona mais é que vós deveis testemunhar maior resolução? Mais uma vez, saibais que é apenas através disso que vós deveis esperar o fim de vossos males; que somente a paciência é capaz de vos fazer vencer vossas penas”. Certamente, se deixarmos a Razão nos falar assim, de formar tais pensamentos em nosso espírito, e de corrigir desta maneira os sentimentos que temos pelas coisas, nós as experimentaremos como sendo inocentes; elas não nos causarão problemas; e não encontraremos nada que seja duro ou difícil.

Nós acusamos erradamente as coisas, lhes fazemos injustiça quando pensamos que elas se opõem à realização de nossos desejos; visto que elas não têm poder sobre nós, a não ser aquele que nossa Opinião lhes dá. Elas são incapazes de nos fazer o mal, a não ser aquele mal que nós lhes cremos capazes de nos fazer. Nisso, certamente, nossa condição é muito feliz; e devemos sustentar como sendo uma das mais nobres vantagens que nos vem da Razão - não vindo delas a nossa potência, nós as submetemos através de nossos sentimentos; nós as fazemos depender de nós, formando em nós a impressão de que elas nos agradam; e lhes dando a aparência e o rosto que melhor nos parecer. Ora, como, para bem dizer, elas só são aquilo que nossa estima a fazer ser, e como é absolutamente ela que as determina como bem ou mal, nós reinamos o suficiente sobre elas, através disso, sem dúvida; adquirimos o pleno direito de dizer se são boas ou más; não precisamos de nenhum outro título para admiti-las ou rejeitá-las. Como se nós nos encontrássemos cercados por diversos animais venenosos: não estaríamos em mais segurança se eles pudessem chegar até nós, do que se eles, estando próximos, não nos pudessem fazer mal algum; não devemos sofrer com o fato de não termos nenhuma jurisdição sobre as coisas, ou com o fato de elas estarem fora de nosso poder; visto que elas nos são submetidas exatamente naquilo que elas têm que nos pode fazer mal; e visto também que nós temos sua força e seu aguilhão em nossas mãos, por assim dizer. Nós a temos tão seguramente que, certamente, sem nós, elas não têm nem movimento 
nem vida. É somente a nossa Opinião que as faz contrárias ou favoráveis; que lhes dá armas ou as tira de suas mãos; que faz delas antídotos ou venenos. Sendo assim, qual é a razão, eu vos pergunto, para que nós temos para apreendê-las? Certamente que o mais tímido dos homens não temeria em nada um Leão que não tivesse nem dentes nem garras. Um Basilisco cego não é capaz de nos fazer mal algum; um Tigre desarmado de suas garras também não. Por que, então, caluniamos as coisas? Elas, por si mesmas, são inocentes e puras; elas não têm veneno, a não ser aquele que nossa imaginação derrama nelas. Elas não têm nem tintura nem cor; elas não têm nem sabor nem gosto. Segundo nossa Opinião as pinta e tempera, elas se tornam agradáveis ou desagradáveis, elas ficam doces ou amargas. Nesse sentido, admitimos o pensamento de Epícteto que lhes dá duas alças - uma das quais, as torna pesadas e difíceis de carregar; enquanto que a outra as torna leves e manejáveis; por aquela, nós só encontramos pena nas coisas; por essa, porém, nós encontramos facilidade. Nada nos chega da Fortuna que não tenha dois aspectos e que nossa Opinião não nos faça imaginar diversamente; a essas pinturas engenhosas que, vistas de viés, têm um aspecto diferente daquele que têm quando vistas de frente; que de um lado representam um esqueleto assustador, e do outro, uma escultura ridícula, e vistas de frente representam um belo rosto. Estes dois Filósofos da Antiguidade - Demócrito e Heráclito -, um dos quais tinha na vida humana um perpétuo motivo de riso, e outro que a entendia como motivo de lágrimas, tinham um mesmo objeto em vista e duas ações tão contrárias resultavam disso; eles não estavam vendo coisas diferentes, mas eles as viam diferentemente e em situações diversas. $\mathrm{O}$ mesmo ouro que Crasso adorava ${ }^{55}$, Cúrio desprezou ${ }^{56}$. Todas as coisas têm, assim, duas faces a partir das quais elas podem ser consideradas; elas têm dois vieses e duas direções - um agradável e outro não.

Esta é uma verdade da qual nós podemos razoavelmente duvidar; sabendo, como sabemos, que a mais agradável de todas as coisas, aquela cuja propriedade mais sua é agradar, que só possui características amáveis e encantadoras - a Beleza mesma - pode ser olhada a partir de um ponto de vista desagradável. Pensemos nela a partir do lado que é estranho aos bens do espírito e que, consequentemente, a partir daquele lado que não a tem entre o número daqueles bens que compõem a felicidade perfeita. Consideremos, eu vos peço, o poder absoluto que o tempo tem sobre ela; os ultrajes que ela recebe por causa de sua inconstância; as visíveis e cruéis marcas que ela carrega dos castigos recebidos. Que alegria nós seríamos capazes de estabelecer, que segurança poderíamos ter nas coisas mais frágeis e inseguras do mundo? Certamente que, por mais frágil que seja o vidro, é possível dizer que ela é incomparavelmente mais frágil. Ele só se quebra se algo bater nele com força; se se evita o choque ou a queda, se evita a sua ruína; mas ela cai sem que nada a toque; ela se destrói, na medida mesma em que subsiste; é uma flor que murcha e desvanece tão logo desabrocha; ela perde seu lustro enquanto brilha; ela decai na medida em que se mantém; ela dura apenas para perecer. Se aquilo que, em nós, há de mais firme e consistente vai embora, que aparência, o que de mais vão e ligeiro, pode permanecer? Se a substância passa, que acidente permaneceria? Vós que vos gloriais de vossa beleza, quereis saber o que ela é? Tende apenas um pouco de paciência, e vereis que ela não existe mais; esperai um momento, e experimentareis que ela já acabou quase antes que a tenhamos definido. Que cegueira é

\footnotetext{
55 Certamente, trata-se de Marco Licínio Crasso (c. 115 a.C.-c. 53 a.C.), que foi um patrício, general e político romando do fim da Antiga república; conhecido por haver derrotado a revolta dos escravos liderada por Espártaco, e por sua proverbial riqueza.

${ }^{56}$ Trata-se do mesmo Mânio Cúrio Dentato, sobre o qual já se fez referência anteriormente.
} 
essa a vossa que vos leva a vos estimar felizes por possuirdes uma coisa tão passageira? Pensai que não somente ela não faz nada pelo vosso soberano bem, como também ela pode mesmo encher-vos de tristeza, sobretudo se e ela não estiver acompanhada de uma alma inocente e direita; por si mesma, ela não vale nada e não é digna de nenhuma estima, e não pode ser considerada justa, a não ser se a justiça vier da virtude. Certamente, sem a virtude, não há nada mais do que nos possamos gloriar. Não há bem algum, senão este. Fora disso, não seríamos capazes de pretender legítima satisfação de todas as liberalidades da Natureza e da Fortuna.

Assim, as coisas têm, portanto, para nosso olhar, duas faces. Não há dúvidas de que tenham duas alças como dissemos antes; mas é preciso segurá-las pela alça boa, através da qual elas são capazes de nos dar algum alívio. Um Lacedemônio vendo-se ridicularizado por ser manco e aparentemente inadequado para as penosas funções da guerra, não tendo deixado, porém, de ir, virou a coisa de outro lado e tornou vantagem aquilo que parecia ser algo para a sua confusão, dizendo que queria combater e não fugir, como que querendo dizer que, lá, na guerra, ele agiria não com suas pernas, mas com seus braços ${ }^{57}$. Esta habilidade foi anda felizmente praticada por outro da mesma nação que, estando condenado à morte, não somente não se zangou e se abandonou, como é comum aos homens em ocasiões semelhantes, à dor e às lágrimas, mas testemunhou alegria, respondendo àqueles que chamavam sua atenção e que o acusavam de desprezo pelas leis que ele estava contente de poder pagar uma dívida, que ele não havia exigido nada de ninguém e que, portanto, ninguém tinha o direito de exigir nada dele $e^{58}$. Um e outro olhava as coisas a partir do ponto de vista que lhes permitia aproveitar algo delas; não ignorando que não há nenhuma que seja tão dura e tão incômoda que não tenha algum lado agradável e ao qual não se possa dar uma interpretação favorável. Para apoiar esta verdade sobre outro exemplo vindo desse mesmo povo, valho-me daqueles trezentos soldados que, das muitas tropas que os Gregos opuseram aos esforços Persas, tiveram a segurança de permanecerem sozinho no famoso estreito de Termópilas e que, por uma gloriosa morte, adquiriram uma reputação imortal e não encontraram razões para justificar sua fuga, nem mesmo para torná-la honrosa $^{59}$. E, para bem dizer, quanta aparência pode haver no fato de tão pouca gente pudesse se opor a uma tão grande armada e não se tenha comportado como presa? Será que eles pretendiam trazer a Vitória justamente num lugar onde era inevitável que deixassem a vida? Onde toda a sua resistência era incapaz de impedir sua perda, e só era capaz de retardá-la? Se, certamente, para eles, isso era uma loucura - pensar em vencer um inimigo tão poderoso e numeroso, que transportou montanhas, cobriu vales, aplainou precipícios, secou rios, fez o mar gemer sob a grandeza e a quantidade de seus navios, enfim que venceu a Natureza em todas as partes por onde esteve -, eles sabiam que deveriam, por assim dizer, agir corajosamente e com conhecimento do perigo, ou se

\footnotetext{
${ }^{57}$ No original latino, Nieremberg escreve: "Visus est Androcidas ineptus miles, quod claudus descend eret in aciem, \& propterea increpatus...”. Não encontramos, porém, referências acerca desse personagem - Andrócida.

58 No original latino, aparece: “Theramenes, opinor, sive alius alitus Lacedaemone animus, innocenti capulo prehendit fatum...”. Trata-se, portanto, de Terâmenes, político ateniense, que viveu no século IV a.C.; foi um dos principais idealizadores do golpe de Estado que instaurou o governo dos Trinta Tiranos; foi morto, após se opor aos excessos do tirano Crítias.

${ }^{59}$ Assim escreve Nieremberg no original latino: "Lacones, sive trecenti, sive sexcenti fuissent, qui aliis ex omini Graecia effugientibus Xerxem, relicti sunt, suam quoque satis honorare fugam possent”. É conhecida a história da tropa de Leônidas - formada por trezentos homens - que ofereceu resistência aos exércitos de Xerxes I, também conhecido como Assuero, no estreito de Termópilas.
} 
precipitarem cegamente e por desespero. Eles não ignoraram que havia uma diferença entre temeridade e coragem. Como sempre, eles sabiam da estima de valor que os Gregos têm de si; eles temiam a censura de ter exposto imprudentemente ao furor dos Bárbaros uma vida que eles deveriam empregar para a salvação de sua pátria; e não tendo nisso outra testemunha de sua virtude além dos inimigos, para quem a virtude era odiosa - visto ser ela, para eles, fatal -, eles poderiam muito bem ser acusados de ter entregue sua reputação nas mãos daqueles que a apagariam e enterrariam seus nomes num eterno silêncio. Por que, portanto, eles não fugiram, visto que eles poderiam fazer isso não somente sem vergonha, como também com honra? Porque eles olharam para a coisa a partir de outro lado; e, para usar dos termos que vimos empregando, eles a tomaram por outra alça. Que razão eles teriam para temer estarem abandonados e sós? Sem dúvida eles creram não estarem nem abandonados nem sós. Os Rochedos que os cercavam eram tropas que haviam vindo em seu socorro, e serviam como amparo, e agiam, ao mesmo tempo, como defesa e como companhia. Pois bem, eles teriam que combater num estreito incômodo e com tão pouco espaço? Tanto mais lhes foi vantajosa esta situação, visto que, estando juntos, a união de suas forças tornava sua resistência mais poderosa; e além do mais, a grandeza e a extensão de sua coragem reparava os inconvenientes que poderiam lhes ser causados pela pequenez e por outros defeitos do lugar. Eles eram apenas trezentos; a bem dizer, eles eram apenas um punhado de gente; mas cada um se contava como vários e cria valer o mesmo que uma multidão, sustentando-se sobre esta verdade universalmente reconhecida, segundo a qual os Lacedemônios se estimavam por seu valor e não por seu número. Eles se consideravam uma tropa escolhida, segundo o consentimento comum daqueles que voluntariamente cederam toda a honra desta ação e não quiseram fugir. Nós, aqui, não somos muitos, eles diziam, para defender nossa pátria, apenas o suficiente para mostrar nossa virtude; nunca haverá ocasião melhor para isso. Podemos dizer corajosamente: eis o dia de nosso triunfo. A fuga não seria desonesta para outros; mas o simples pensamento da fuga nos seria eternamente censurável; seria suficiente para que nos considerassem infames se simplesmente tivéssemos colocado isto como opção para uma deliberação. Aqui, a honra não é menos eminente que o perigo; se aqui a vitória é duvidosa, a glória é infalível. Os Atenienses não teriam ido embora se houvesse alguma certeza de vitória; os Lacedemônios permanecem onde eles estão certos que morrerão. Xerxes revirou as montanhas, secou os rios, mudou a aparência da Natureza. Tudo isso foi mais fácil, para ele, do que abalar nossa firmeza e nos fazer mudar a decisão. Que ele saiba que esta prodigiosa potência com a qual ele nos quer maravilhar, e que ele acha não ter limites, se encontrará, hoje, na impossibilidade de nos arrancar o coração. É nisso que seremos superiores a todos os seus esforços; e nisso a Vitória permanecerá conosco, mesmo depois de havermos perdido. Não haveria nisso, sem dúvida, motivos suficientemente poderosos para fazê-los assumir o partido contrário àquele que as razões lhe davam? E não parece que, se eles poderiam fugir honrosamente, também poderiam permanecer gloriosamente?

Mas, esta habilidade de tomar as coisas pelo lado onde elas não machucam, por onde elas não são rudes e maldosas, é-nos sobretudo necessária nas armadilhas e nas perseguições que a Fortuna prepara para nós. É nisso que ela tem seu uso mais justo e natural; e, sem dúvida, é justamente nisso que devemos mais praticar. Aquele, entre todos os males, de que os homens mais são presas na vida, contra o qual é preciso os maiores poderes e os mais frequentes remédios - a Pobreza - vem até a nós? Não consideremos as riquezas a partir do lado que as mostra como aquilo que serve às delícias; não as representemos como ministras da Volúpia, mas como Tiranos da 
Virtude; que é o lado pelo qual elas nos causam pena, e são motivo de depravação e devassidão. Pensemos que não há razão alguma de nos afligirmos por sua perda, ou que nos lamentaremos de nos termos curado de uma doença que, nos mantendo em perpétua inquietude, nos arrancaria o gosto dos verdadeiros e legítimos prazeres, e perverteria nosso espírito, até ao ponto de torná-lo incapaz do sentimento de sua felicidade própria. Lembremo-nos de que não há nada que tenha menos capacidade de se manter do que as Riquezas; que, por mais maciço e pesado que seja o metal que as componha, elas são extremamente ligeiras; elas mudam constantemente de lugar; elas não têm nem postura nem firmeza. Caçoemos da inconstância da Fortuna, ao invés de nos deixarmos ferir por ela; e nos desenganemos do erro no qual caímos ao crer que ela nos dá bens verdadeiros; recorramos à Virtude, de quem podemos, de fato, esperar os bens verdadeiros, e cujas liberalidades são incomparavelmente maiores e constantes; nos dão abundantemente aquilo de que precisamos e nunca nos arranca aquilo que, uma vez, nos deu. Ela não deixa faltar nada a nós, daquilo que ela acredita que podemos tirar algum proveito. Se há algo que ela nos recusa, é tão somente aquilo que ela acredita que será causa de ruína para nós, e aquilo que só poderia ser fruto de sua liberalidade se ela fosse nossa inimiga. Por que nos incomodamos com as perdas, se podemos adquirir de volta aquilo que perdemos com muito mais vantagem? Se está apenas em nós retomá-los com nossos próprios fundos? Certo: estamos errados de nos lamentarmos da Pobreza, tendo, como temos em nós, um pronto, um infalível meio de nos garantirmos contra ela; sendo suficiente para nós, nisso, tão somente reprimir nossos desejos e corrigir nosso apetite. Aprendamos que não há via mais segura para se tornar rico do que não desejar nada. Sem dúvida, tornaremos nosso tudo aquilo que não quisermos; adquiriremos, possuiremos todas as coisas, ao não ter paixão por nenhuma. Não nos é possível viver magnificamente? Não temos motivo para nos animarmos? Não olhemos para aquilo que nos agrada, mas para aquilo que nos é suficiente. Não acreditemos no gosto, que só busca a abundância e o luxo; mas acreditemos na Natureza, que pede a mediocridade ${ }^{60} \mathrm{e}$ que é inimiga do excesso. Tendo pouco para comer, não nos deixamos levar pela Volúpia. Somos mais sãos e menos malvados, fechamos as portas para os vícios que a acompanham e não deixamos entrar em nós nada além dela, evitamos as enfermidades e as doenças que ela atrai em seguida. Regozijemo-nos do fato de que a Pobreza nos obrigue à sobriedade, nos faz ser, por necessidade, aquilo que que deveríamos ser voluntariamente. Pensemos que uma comida leve produz, ordinariamente, uma saúde firme e vigorosa; e - o que não é menos importante - nos dá uma disposição grande para a prática do bem; nos torna mais hábeis e mais preparados para o exercício da Virtude. Mas, nos incomoda ainda sermos privados dos prazeres de comer? Temos dificuldades para renunciar às delícias da boca? Pensemos em Epicuro e nos encontraremos, como ele, numa vida mais simples e austera do que aquela a que nos reduzimos. Nós o encontraremos na abstinência, e experimentaremos que é verdadeiramente nisso que consiste a Volúpia, que pensamos estar na opulência e das superfluidades. Falharam nossas esperanças? Descobrimo-nos decepcionados em nossas pretensões e expectativas? Não pensemos nas vantagens que não obtivemos, mas para os inconvenientes que evitamos. Não olhemos para a eminência do lugar onde queremos chegar, mas para a profundidade do precipício onde podemos cair; e pensemos que nossa elevação pode ser a causa de nossa ruína. Lembremo-nos de que o orgulho das Torres é abatido pelas tempestades e pelo relâmpago; e que a baixeza das cabanas está protegida; e de que a mediocridade ${ }^{61}$ é, ordinariamente, acompanhada da segurança.

\footnotetext{
60 Trata-se do conceito de meio-termo ou de indiferença.

${ }^{61}$ No texto latino, Nieremberg usa o termo mediocritas, que significa meio-termo, ou indiferença.
} 
Pois bem, somos excluídos do emprego no qual gostaríamos de estar; a dignidade que pedíamos foi-nos recusada; não pensemos que, por isso, ficaremos ofendidos e que seja preciso tomar esta recusa como uma injúria. Nisso, só se fez aquilo que deveríamos ter feito nós mesmos. Imprimiu-se nossa ambição? Devemos, sem dúvida, corrigi-la. Imitemos a Sabedoria da Natureza na união maravilhosa das partes que compõem o Universo. Toda inimizade que reine entre elas, por causa de suas qualidades contrárias e opostas, vemos como são colocadas juntas numa paz comum e vivem em amizade. Assim, por mais que o fogo não esteja de acordo com o ar, visto que aquele é seco e este úmido, eles se unem porque ambos são quentes, e nisso está o vínculo de amizade que os une. $\mathrm{O}$ ar e a água são verdadeiramente inimigos, por causa do calor do primeiro e do frio da outra; mas, para além disso, eles se dão as mãos, eles se ajustam na sua umidade comum. Da mesma forma a Terra árida e seca que não é compatível com a água, na medida em que esta última é úmida, mas elas se aliam, visto que ambas são frias. E assim, chocando-se por um lado, se abraçam por outro, e formam entre si uma estreita amizade. Saberíamos ser melhor instruídos que por isso, por esta importante verdade, segundo a qual não é preciso, de forma alguma, tomar as coisas a partir do lado que evidencia o mal que elas nos fazem, mas a partir daquele que mostra como elas são capazes de trazer algum proveito?

\section{TÓPICOS PRECEITUAIS SOBRE O USO DA OPINIÃO}

\section{PRIMEIRO LUGAR}

\section{Da comparação com a Fortuna}

No entanto, a fim de nos desenganar mais felizmente e nos tornar mais útil e salutar o uso da Opinião, apresentaremos algumas Máximas, e esta será a primeira: compararmo-nos, nos desprazeres e nas desgraças que nos acontecem, com a Fortuna dos outros. Nisso, sem dúvida, estará motivo suficiente para que não nos ressintamos desses desprazeres e desgraças: por mais malvado que seja o tratamento que recebamos da Fortuna, não nos acreditaremos infelizes; às vezes, inclusive, encontraremos nisso naquilo que pensamos ter motivo para a tristeza - motivo para alegria. Consideremos seriamente, em seguida, esta importante verdade, pronunciada por um grande homem: que não é necessário acreditar um mal aquilo que outro crer ser um bem ${ }^{62}$. Caímos na pobreza? Por que nos abandonamos à dor, se outras pessoas, em situações semelhantes, consolam-se mais facilmente? Não é verdade que antes que tivéssemos tido o bem, ficamos sabendo que ele coincidia com a alegria? Eis-nos, de novo, nos mesmos termos, de volta àquele estado capaz de contentamento; regozijamo-nos, qual a razão que temos para nos afligir? Acontece de sermos frustrados em nossa expectativa? Teremos menos do que esperamos? Teremos menos do que o que nos é necessário? Teremos motivo para nos maravilharmos com o fato de nos encontrarmos acima de nossas esperanças, tendo levado-as para além do dever e da razão? E haverá motivo

\footnotetext{
${ }^{62}$ No original latino, Nieremberg escreve: "Sapienter Barbarus sapiens ait: Non est malm, quod cum alio comparatum bonum est”, não se referindo, portanto, a um personagem específico. Será necessária uma pesquisa com a finalidade de identificar, entre os autores comumente citados por Nieremberg, aquele que melhor represente a ideia apresentada.
} 
para se espantar com o fato que, sendo ilegítimas e sem fundamentos, elas se arruínem? Sem dúvida, esperando mais do que deveríamos, é justo que tenhamos menos do que esperamos. Avalio que perdemos muito, mas ainda nos resta algo. Eis o erro ordinário de todos os homens, que é considerar eternamente aquilo que lhes falta, e nunca pensar naquilo que têm. Esquecendo aquilo que permanece, nós nos arrancamos tudo o que temos, e tratamos a nós mesmos com mais rigor do que tratamos a Fortuna que se entregou por nós. Aqui, somos como crianças: se alguém lhes tira seus brinquedos, eles jogam, por despeito, todos os demais; e, porque não lhes dão aquilo que querem, elas não querem nada. Será que não ouvimos falar daquilo que aconteceu a Sócrates quando conversava com alguns de seus amigos? Como eles estavam indo se colocar à mesa e Alcibíades veio e levou metade da carne. E como Sócrates, ao invés de se ofender, assumiu um sentimento contrário, testemunhando obrigação para com Alcibíades, na medida em que este, podendo levar toda a carne, deixou uma parte ${ }^{63}$. Devemos agir igualmente com a Fortuna, agradecendo-a por aquilo que ela nos deixa, e não nos incomodando em nada com aquilo que ela nos tira. Ela nos tira menos do que nos dá; os bens que dela recebemos merecem que soframos com seus maltratos, sem que murmuremos. Ela reparou, talvez, com alguma outra coisa o mal que nos fez. Se é uma falta que ela cometeu, pode ser que, mais tarde, ela a corrija. Depois de tudo, não é mais razoável regozijarmo-nos com as coisas que nos ficam, do que nos afligirmos com aquelas que perdemos? Da mesma forma como elas estão fora do nosso poder, que elas estejam fora da nossa memória. Não pensemos nelas mais, sobretudo se elas não foram nossas; não pensemos que nossa condição é pior só porque não as possuímos. Sintamos prazer pelas coisas presentes, e deixemos perder o lamento pela perda da posse. Por que nos cremos infelizes se, comparando-nos aos outros, justifica-se não apenas que não o somos, como também que temos motivo suficiente para louvar nossa fortuna? Regozijemo-nos muito mais com o fato de que ela poderia ser pior e com o fato de um mal maior poderia nos chegar. Não levantemos os olhos para olhar de onde caímos; mas os abaixemos, para ver onde ainda podemos cair; e reconheçamos a graça que nos garantiu ir até ao fundo do precipício. Que nos aconteça que muitas pessoas queiram seram infelizes como nós o somos; e que aquilo que chamamos nossa miséria seja sua felicidade. Aristipo, tendo perdido um fundo que lhe trazia muita felicidade, não apenas não ficou chateado, como também consolou aqueles que se afligiam; e como um adulador parecia sentir mais dor do que os demais, ele lhe disse: Meu amigo, tens apenas um pequeno fundo, e eu ainda tenho três; tens muito mais motivo para te lamentares do que eu. Acredito que tua condição seja ainda mais infeliz do que a minha. Ele soube, através disso, acalmar sabiamente o mal-estar que ele poderia ter por sua perda; ele nos deu o exemplo daquilo que devemos fazer quando nos encontramos acolhidos por uma semelhante ou maior infelicidade.

Isso, no entanto, não é suficiente para nos curar e nos arrancar o lamento pela perda. Certamente, se ela é ligeira, por isso mesmo será pouco sensível, não podemos considerá-la com o mesmo preço daquilo que nos resta. E, se ela é grande, há muito mais motivo para nos regozijarmos do que para nos afligirmos. Este sentimento poderá parecer possivelmente pouco razoável no início; mas só o será para aqueles que não sabem ainda de que inquietudes e apreensões as riquezas vêm acompanhadas; que não sabem que sua posse, assim como sua perda, nos deixa em perpétua inquietude; não sabem que elas nos fazem sofrer incessantemente e são incompatíveis com a paz e o

\footnotetext{
63 Alcibíades Clínias Escambônidas (c. 450 a.C. - c. 404 a.C.) foi um general e político ateniense, amigo e entusiasta do filósofo Sócrates que, em 432 a.C., lhe salvou a vida.
} 
repouso do espírito. Se perdemos muito, teremos, daí por diante, menos motivo para temer; ficamos livres dos muitos cuidados; e, então, teremos menos problemas. Que loucura a nossa de nos crermos, no entanto, miseráveis! É uma loucura visto que, se nos contentarmos com o que nos resta, e se reprimirmos nossa cobiça, tornaremos melhor a nossa condição e seremos mais felizes do que fomos. Certamente, há muita injustiça em não querer apenas aquela que nos fez muito bem; que, nos tendo dado tudo, poderia, sem dúvida, nos tirar tudo, e teria o direito, pelo menos, de retomar para si parte do que nos deu. Não sejas injusto acreditando ser um dano teres restituído a ela o que é dela, mas crê ser um ganho teres recebido dela o que recebeste. Pensemos que estava em seu poder retirá-los de nós; que nós os havíamos possuído por muito tempo; que, pelo tratado que tínhamos com ela, não nos era permitido mantê-los por mais tempo. Mas, sobre todas as coisas, tenhamos muito cuidado com, comparando nossa condição com a de outros, não prestemos a devida atenção a nós mesmos. Assim como não há fortuna tão grande que seja contente de si mesma - tanto que ela sempre encontra uma que a ultrapassa ou que a iguala -, também não há nenhuma fortuna tão pequena que não seja satisfeita ou, pelo menos, consolada tão logo se dá conta de que não estão no mais baixo grau e que há uma abaixo dela. Esta máxima, no entanto, só é aplicável aos bens do mundo. E é somente nisso que é necessária uma grande precaução de não tirar os olhos de nós. Mas, é preciso usar, pelo contrário, naqueles bens do espírito e, sobretudo, nos bens que vêm da Virtude. Porque, como os primeiros só merecem desprezo, só nos restam os outros que sejam dignos de nossa estima e que possam, legitimamente, ser objeto de nossa ambição. Assim como devemos olhar para as riquezas temporais como olhamos para aqueles que nos são inferiores, é preciso, quanto às riquezas do Céu, nos propormos como superiores a nós, imitando-as a todo custo e, por uma inveja nobre e generosa, não sofrermos com o fato de que elas tenham vantagem sobre nós. No entanto, para além do fato de nos compararmos como os outros, é preciso também nos compararmos conosco mesmos; pela inferioridade e desvantagem de nossa fortuna, comparada com o nosso mérito; e recompensando pela satisfação que nos dá este, os problemas que nos vêm daquela. Este remédio foi muito felizmente praticado por Ágis, um dos maiores homens de Esparta ${ }^{64}$. Vendo que ia ser morto sem razão, ele não se divertiu exagerando sua infelicidade com lamentos inúteis, como fazem os homens do vulgo. Ele se fortaleceu de tão maneira com a consideração de sua inocência contra os rigores da Fortuna, que chegou mesmo ao ponto de desafiá-la, além de desafiar também seu mau destino. E como ele percebeu que o Executor, tocado pela compaixão, chorava e não conseguia colocar as mãos nele, ele lhe disse: Cumpre corajosamente o teu dever, e saiba que, morrendo injustamente, serei mais um homem de bem, valho mais do que aqueles que me condenaram. Pronunciando estas palavras, ele se apresentou com alegria à corda; e apagando a ignomínia de seu suplício pela glória de sua virtude, ele fez para si um colar de honra com uma corda infame.

\section{SEGUNDO LUGAR}

\section{Da contingência}

\footnotetext{
${ }^{64}$ Não está claro a qual dos Ágis se refere Nieremberg. Seja como for, ao que tudo indica, trata-se de Ágis I (c. 930 a.C. - c. 900 a.C.), um lendário rei espartano, que fundou a dinastia Ágida.
} 
Estes dois meios infalíveis de conseguir nosso repouso, pelo legítimo uso da Opinião, já estando bem estabelecidos, nos abrem o caminho para a prática de um terceiro; que nos virá de uma reflexão que faremos em nós mesmos: que um mal maior do que aquele de que nos lamentamos pode nos chegar. Esta casa que construímos com tantas despesas e cuidados pegou fogo? Vimo-la caindo em ruínas? Consolemo-nos desta maneira ou, para mais bem dizer, testemunhemos assim a nossa alegria: "Eis a minha casa por terra, mas eu não cai com ela; estou vivo e inteiro; encontro-me são e de pé. Se ela incomodou minha fortuna, ela não fez mal algum à minha pessoa; não fui soterrado por suas ruínas; posso esperar por uma tumba mais nobre. Perdi minha prataria, afundaram-se meus mais belos móveis; mas me deixaram a vida. Aqueles que me roubaram poderiam ter feito pior. Tendo contentado sua avareza ao levar minhas riquezas, eles poderiam satisfazer também sua crueldade pela efusão do meu sangue. Isto não me tendo acontecido, não seria motivo suficiente para que eu louve minha fortuna? Não tenho, por isso, motivo de me crer feliz, não tendo caído numa tão grande infelicidade? Será que o que me levaram tem tanto valor que mereça se comparar ao que me resta? Que bem pode ser tão mais precioso que a vida? E, visto que eu ainda a tenho, será que deverei me lembrar de minhas perdas, sendo que tenho com o que as reparar? Quantos homens se perderam apenas porque eram ricos? Quantos se viu cujos empregados e familiares derramaram o sangue a fim de obter os bens? Isto ainda pode me acontecer. E se eu fosse reduzido a esta miserável eleição entre morrer e abandonar minhas riquezas, será que eu não tomaria este último partido? Será que isso seria difícil para mim? O viajante que cai nas mãos de ladrões dá livremente a sua bolsa, para salvar a sua vida. Aqueles que estão perto do naufrágio jogam no mar tudo o que têm, eles ficam contentes de perder tudo para não afundarem. Para que uso mais digno e necessário se poderiam empregar os bens do que para a conservação do mais caro e nobre de todos os bens? Com o contentamento de ainda poder gozar deles, tenho a vantagem de não os dever a ninguém; não me vi ainda numa tão deplorável situação extrema de ter que esperar a vida da mercê de um ladrão, de um mal parente ou de um empregado. Minha condição pode, portanto, ser pior do que é. Não terei, por isso, mais motivo de me regozijar do que de me afligir?”.

Tivemos uma honra pública recusada? Não creiamos que isso seja uma infelicidade como o fazem os homens do vulgo; e guardemo-nos de nos afligirmos; discorramos assim dentro de nós: "Quem pode me assegurar que, se eu tivesse ficado mais tempo nesse cargo, a Inveja e o Ódio que se ligam àquilo que há de eminente e, ordinariamente, perseguem aqueles que estão acima dos outros, não me teriam arruinado? Sabendo, como sei, das desordens que elas causam no mundo e aprendendo, pelos grandes exemplos que se vê, sem cessar, de sua crueldade, que elas não perdoam a ninguém e nunca fazem o mal pela metade, eu não deveria entender que, não estando contentes por destruir minha fortuna, elas não teriam tomado também a minha pessoa, elas não teriam envolvido na mesma ruína geral a minha honra, as minhas riquezas e a minha vida? Se houvesse alguém que, prevendo a minha derrota, me tivesse assistido com seus conselhos, cuidados e próprios bens para preveni-la, e me tivesse dada o meio de conseguir uma honrosa aposentadoria, ele não me teria, com isso, obrigado extremamente? Há algum tipo de reconhecimento que eu não deveria a ele? Eis-me, presentemente, no estado no qual estarei então. Tenho tudo aquilo que poderia desejar, tendo minha reputação inteira, meus amigos, meus bens e minha vida. E mesmo a Fortuna, que por uma graça particular e que ela faz raramente àqueles que ela elevou aos grandes cargos, não me deixou descer de onde ela poderia me ter precipitado. E não me tendo sido cruel, não me foi também liberal; e não me tirando coisa alguma daquelas que 
ela costuma arrancar dos outros”. Caímos doentes? Mesmo isso não é sem consolação; muitas vezes, inclusive, se pode encontrar nisso motivo para alegria. É possível, com isso, evitar alguns violentos ultrajes da Fortuna; estamos protegidos de muitos males que poderiam nos chegar. Se nossa indisposição não nos mantivesse no leito, nós iríamos aos lugares de dissolução e de devassidão, aos lugares onde o vício é aprendido e exercitado. Não teríamos os movimentos que nos vêm e que nos impelem à reforma de nossa vida, à conversão a Deus, a ser gente de bem. Seríamos cúmplices de qualquer desordem que se poderia cometer enquanto isso e que causaria possivelmente nossa morte ou nossa infâmia. Estaríamos na cidade ou no campo e, por isso, facilitaríamos o efeito dos desígnios de um inimigo, que nos prepara emboscadas e nos procura para exercer sobre nossa sua vingança. Estaríamos, talvez, em algum perigo iminente de vida; e, então, gostaríamos de estar onde estamos agora. Compraríamos com o preço de nosso sangue a felicidade de estar de volta ao nosso leito. Desejaríamos a febre que nos faz sofrer; ficaríamos felizes de poder ter a cólica ou a gota. O que mais posso dizer? Daríamos uma de nossas mãos para nos livrarmos do perigo. Ora, nós o evitamos, ficamos isentos dele, sem que ele nos custasse nada. Gozamos da Vida, e logo retomamos a saúde. Não teremos nisso mais motivo para a alegria do que para a tristeza?

\section{TERCEIRO LUGAR}

\section{Acerca dos fins}

Outro meio de que podemos nos servir de forma muito útil da Opinião é considerando o fim e o desenrolar das coisas; estando certo que é nisso que seu disfarce vai embora, que elas não terão mais maquiagem ou máscara, e que elas nos farão conhecer verdadeiramente quem elas são. A Vara que Moisés recebeu da mão de Deus, e que pode ser chamada a missão para com o povo de Israel, tendo sido transformada numa horrível serpente, causou medo no povo e ele fugiu; mas quando Moisés a pegou pela cauda, ela perdeu sua estranha forma e voltou a ser aquilo que era, e voltou a ser uma Vara como antes. Muitas coisas que nos são salutares nos assustam sob uma aparência terrível; e outras coisas que não são perniciosas nos atraem sob uma aparência agradável. Ora, para não encontrarmos nisso motivo de descontentamento, não devemos parar naquilo que se nos aparece de imediato; elas são outras, sem dúvida, no seu advento e quando acontecem; e não seremos capazes de formar um julgamento seguro se não as considerarmos o final. Ouvimos, muito frequentemente, dizer que, no mundo, tudo o que há e que é tido como mais precioso, e sobre o que os homens estabelecem seu soberano bem, com tanto mais infelicidade quanto mais cegueira têm, as honras, as riquezas, as volúpias, não têm nem duração nem firmeza, elas passam como a sombra e se desvanecem com a fumaça. De onde é que pensamos que se pode tirar este conhecimento? Das provas que vemos em todo momento, da experiência ordinária que mostra que elas se reduzem ao nada. Disso, temos motivo para crer que elas não são nada e, mais verdadeiramente ainda, que elas não são nada de bom; visto sempre nos causarem o mal, visto que, por uma ligeira doçura com a qual nos adulam no início, e por um pouco de prazer que nos dão no começo, elas depois nos enchem de dor e de amargura; semelhantes que são àquele inseto que carrega seu veneno na cauda ${ }^{65}$ que,

\footnotetext{
${ }^{65}$ No original latino, Nieremberg escreve: "Scorpium venenantem non timebimus ex adulanti ore; sed a praepostero morfu”. Trata-se, portanto, do escorpião.
} 
primeiro, nos faz cócegas, mas depois nos pica e nos faz morrer. Na verdade, se examinarmos seriamente aquilo que elas nos fazem, se ao invés de deixarmos que elas nos violentem e, para dizer mais claramente, se ao invés de nos deixarmos enganar por seu brilho e sua aparência, considerássemos o quanto o interior é perigoso, tiraríamos disso a grande vantagem de não ter feito, por nós mesmos, esta miserável experiência, evitaríamos o arrependimento que permaneceria em nós. Porque, o que mais uma Volúpia de alguns momentos nos pode deixar além de um longo remorso e um dor pungente? Isso não é suficiente para nos excitar a nos defendermos delas e desprezálas? E, ao invés, nos recusaremos a buscar a Virtude só porque suas abordagens são austeras e difíceis? Saibamos que, ao contrário das Volúpias, ela esconde uma extrema doçura sob uma aparência de severidade; saibamos que ela nos enche de contentamento e que somente ela é capaz de compor nossa felicidade. Se ainda nos resta algum raio de razão, prefiramos, sem dúvida, mais o ganho infalível que ela nos apresenta, do que o mal evidente que recebemos das outras ${ }^{66}$.

\section{QUARTO LUGAR}

\section{Da comparação dos tempos}

Encontraremos ainda muito alívio no levar nosso espírito para além do acontecimento das coisas; imaginando o estado onde estaríamos quando elas não existirem mais; e o que nos acontecerá quando elas tiverem passado. Como aquele que encontra um atoleiro no meio de seu caminho, o cruza com um salto para não se sujar; nós também cruzaremos com o pensamento aquilo que suja a pureza de nossa alma - as delícias e as volúpias - e refletiremos em seguida que, após a sua extinção, quando nossos ardores forem apagados, quando a violência de nossas paixões relaxarem, só nos restará, em meio a tantas satisfações que nos haviam proposto, desgosto e arrependimento. Não tendo encontrado o sólido contentamento que nos haviam prometido, não as desejaremos mais; nós as consideraremos, se não com desprezo, pelo menos com indiferença e frieza. Não seremos tocados por elas e, se não tivermos horror a elas, pelo menos não as desejaremos. Nesse meio tempo, a Razão nos dirá que, quando elas tiverem passado, não restará mais àqueles que se satisfizeram do que àqueles que se abstiveram, que estes e aqueles, nisso, são iguais; e que é um engano acreditar que os primeiros sejam mais satisfeitos e felizes que os outros. Pelo contrário, é certo que, por causa do remorso que elas deixam, eles estão em pior condição; e se há desvantagem, ela é menor do lado daqueles que não as conheceram, do que daqueles que as possuíram. Quantos problemas têm aqueles, enquanto estes saboreiam um repouso grande! A alegria destes é verdadeira e tranquila; e a daqueles, se eles a têm em alguma medida, é inquieta e falsa. Para bem dizer, eles são menos felizes e menos satisfeitos, por mais que o pareçam ser muito.

\footnotetext{
${ }^{66}$ No texto latino, Nieremberg se extende um pouco mais do que seu tradutor, apresentado argumentos que têm como personagens o já citado Faláris (?-554 a.C.), tirano que instaurou o Touro de Perilo como instrumento de tortura; e Pitágoras de Samos (c. 570 a.C.-c. 497 a.C.), o matemático e filósofo: "Prudenter itaque Phalaris scribit. Sapientis viri officium est, ante verba, rem ipsam; ante rem, diligentius quoque exitum considerare. Exitum voluptatum considera, poenitentiam, aut praecipitium. Quid? Exitum considera omnium secundam mundi ianuam, mortem. Audi, \& hauri Samium monitum: Ne imprudenter teipsum habere circa aliquid assuescas; sed cognosce, quod mori fato constitutum est omnibus".
} 
Experimentaremos também o quanto este remédio é excelente contra as diversas infelicidades de que formos acolhidos. Transportemo-nos em espírito um pouco para além do tempo em que elas nos tiverem chegado; imaginemos aquilo que, ordinariamente, acontece nesses encontros, que, por mais pesado que seja o flagelo que caia sobre nós, dois meses se passarão apenas para que nem mesmo nos lembremos mais, para que nossas chagas cicatrizem, para que nos acomodemos outra vez com a Fortuna e para que nos regozijemos como se nada nos tivesse acontecido. Quem nos impede, eu vos pergunto, de antecipar este tempo? E por que, já no presente, não nos colocamos nesses termos? Se é certo que o tempo traz doenças desta natureza tão obstinada, indubitavelmente a Razão é ainda mais capaz de vencer, e devemos esperar ainda mais a nossa cura da firmeza e da constância desta última do que da desigualdade e das mudanças da outra. Assim como é nossa Opinião nos faz sofrer mais do que nosso próprio mal, certamente não há nada de mais fácil do que a corrigir. Arranquemos de nosso espírito esta causa fatal de nossas dores; os males que recebemos da Fortuna serão apenas muito pouco sensíveis. Um dos mais Sábios homens da Lacedemônia, estando num Templo, ocupado com a cerimônia dos Sacrifícios que, segundo a superstição do Paganismo, honravam suas falsas Divindades, foi informado da morte de seu filho ${ }^{67}$. Como ele sabia muito bem da importância da precaução que recomendamos - de antecipar o tempo em que nosso espírito, retornado da desordem na qual algum acidente sinistro o lançou, se recoloca na sua primeira posição, e volta à serenidade e à tranquilidade -, ele não se deixou tocar por esta novidade, como se ela lhe fosse indiferente ou como se ele já soubesse dela há muito tempo. Mas, como se esperavam dele as ordens sobre o que lhe fazer, tendo continuado as suas orações sem as interromper por um suspiro que fosse, nem dar qualquer sinal de tristeza, ele disse: enterrem-no onde julgardes mais a propósito; e não se emocionou nem um pouco. Sem dúvida, ele não ignorava que seu filho não era imortal; ele sabia o suficiente que ele não era feito de uma matéria mais forte do que a do resto dos homens. Ele o considerava como um vaso de barro que não causa preocupação a ninguém quando se quebra. E, da mesma forma que, quando o cerne se separa da concha, nós a jogamos fora, nós a desprezamos; assim também ele pensou que a alma, estando separada do corpo; que este estojo, por assim dizer, não tendo mais esta rica peça de onde ele tira todo o seu valor, importava muito pouco o que seria dele; ele não merecia que se dedicasse muito cuidado para com ele.

\section{QUINTO LUGAR}

\section{Do exemplo}

Praticaremos em seguida outro remédio que não é menos soberano que os precedentes. Ele consiste em nos propormos o exemplo daqueles que estiveram, como nós, na dor e no sofrimento. Nisso, no entanto, é preciso que evitemos imitar o vulgo que, por uma boba e cruel maneira, se consola com a multidão de miseráveis e retira da pena dos outros o alívio e o prazer. Coloquemos, portanto, diante de nossos olhos

\footnotetext{
${ }^{67}$ No original latino, Nieremberg escreve: “Pulvillus perinde contempsit recens nuntium defuncti filii...”. Trata-se de Marco Horácio Pulvilo (séc. IV a.C.), que foi um dos primeiros cônsules romanos do primeiro ano da República (509 a.C.). As fontes clássicas também mencionam Pulvilo como o cônsul que consagrou o templo de Júpiter, construído pelos últimos reis de Roma, no Capitólio.
} 
aqueles que sofreram seu mal com constância; aqueles que o suportaram com alegria; aqueles cuja paciência foi além dos termos ordinários. Pensemos naquele nobre Cidadão de Reggio ${ }^{68}$ que Dionísio, o Tirano, que havia cercado a cidade, o amarrou a uma máquina destinada a derrubar as muralhas; a fim de que aqueles de dentro se detivessem pelo temor de causar algum mal àquele que tanto bem havia feito à pátria, de forma que sua vida, certamente, lhes devia ser muito cara. Pensemos nele solicitando e gritandolhes para virarem suas armas para aquele lado; para não o pouparem, a fim de não caírem no inconveniente de pouparem seus inimigos; e, por uma ruinosa consideração por sua salvação, se tornassem autores de sua própria perda. Seguramente, sentiremos vergonha de ver que se tenha matado um homem que tenha desejado a morte, que a tenha pedido insistentemente e com as mãos juntas; e que não sejamos capazes de suportar os menores males que nos façam sofrer minimamente. Se não tivermos perdido completamente a razão, enrubesceremos diante de nossa impaciência, ao considerar sua invariável firmeza. Com isso, nos lembraremos da fragilidade de nossa condição, e de que não há nada que diminua tão potentemente o peso dos fardos que ela nos impõe do que pensar que é absolutamente necessário que nós os carreguemos e que não seremos capazes de nos defender deles. Nós diremos: "não somos Deuses, mas homens frágeis e mortais; é inevitável que soframos. Todas as coisas de que nos lamentamos são necessariamente causadas pela enfermidade de nossa Natureza”.

\section{SEXTO LUGAR}

\section{Da razão da providência}

Quanto ao mais, se os Sábios do Paganismo - que só tinham as luzes naturais e não eram iluminados do alto como nós o $\operatorname{somos}^{69}$ - descobriram que era um grande alívio para seus males pensar que eles os deviam necessariamente sofrer; se eles tomaram a resolução pela paciência, a partir da consideração da ordem imutável do destino; que vantagem teremos nós e que meio maior do que esse para acalmar nossas penas e problemas? Sabendo, como sabemos, que não é puramente por necessidade que os sofremos, mas porque agrada a Deus, cuja única vontade nos determina àquilo que melhor que parecer, nos governa soberanamente e realiza todo o nosso destino. O que poderia haver de desagradável naquilo que vem dele? Que acidez ou amargura poderíamos temer encontrar nessa bebida que ele nos apresenta? Sejamos sérios: não é o destino que nos força e que nos leva, mas é Deus que nos atrai e nos conduz. Se queremos saber para onde Ele nos leva, fiquemos certos de que é direto para ele; mas que nossa curiosidade não passe disso e não se coloque a pergunta sobre a via pela qual

\footnotetext{
${ }^{68}$ Assim se lê no original latino: "Composuit Python Rheginus mortem cum gloria virtutis, \& animose provocavit concives", que poderia ser traduzido assim: "Pitão de Reggio viveu a morte com a glória da virtude; e animadamente provocou seus concidadãos”. O nobre cidadão a que se refere o tradutor é o filósofo pitagórico Pitão de Reggio (séc. IV a.C.), que viveu em Reggio, na Sicília, durante a tirania de Dionísio I.

69 No original latino, Nieremberg escreve: "Caeterum in plurimis, fatorum consideratio Demetrium impulit, pluresque antiquorum ad malorum opinionem ponendam, aut portandam; scilicet, necessitatis lex coegit ad patietiam"; o que poderia ser traduzido assim: "além do mais, em muitíssimas coisas, a consideração dos fatos estimulou Demétrio e muitos outros antigos a deporem as opiniões sobre os males ou carregá-las consigo; ou seja, a força da necessidade os coagiu à paciência”. Ao que tudo indica, tratase do mesmo Demétrio I, da Macedônia (337 a.C.-283 a.C.), citado anteriormente.
} 
ele nos levará. Tratá-lo-emos com mais indiscrição do que tratamos um guia ou um Cocheiro a quem deixamos que siga o caminho que quiser? Quereremos prescrever-lhe uma rota, quando não prescrevemos ao Piloto sob a conduta de quem embarcamos? $\mathrm{O}$ que importa o caminho que ele quer que sigamos, visto que chegaremos onde queremos? Mas, nos lamentamos de que Deus nos conduz por um caminho rude e acidentado, por um caminho coberto de pedregulhos e cheio de espinhos. Não duvidemos que este seja o mais curto e o mais seguro. E não o tenhamos por sem beleza, considerando que ele é de sua escolha, e lembrando-nos da suficiência e da bondade de um tal guia. Será que somos mais esclarecidos e mais sábios do que ele, para querermos lhe ensinar aquilo que ele deve fazer? Certamente, é um raro alívio, para nós, repousarmos sob seus cuidados e sob sua providência. $O$ que fazem, ordinariamente, as grandes almas é se colocarem entre os braços de sua suprema sabedoria. Mas, este discurso, exigindo maior extensão do que podemos aqui, será deixado de lado, para que o retomemos em outro ponto.

\section{TERCEIRO ENSINAMENTO}

\section{Separar-se da opinião}

Eis como, por esta indústria da Opinião corrigida e convertida a um bom uso, acalmaremos as agitações de nosso espírito, pacificaremos os conflitos e os movimentos de nossa Vontade. Por mais difícil e intratável que ela possa ser, a satisfaremos plenamente; ela não terá mais do que se lamentar; fecharemos inteiramente a sua boca. Ora, como ela é flexível e dócil, como não é de sua natureza que ela se torne problemática e rebelde e que, se ela o é, deve-se apenas à falta de instrução e de disciplina, a venceremos e ela abraçará o bem onde quer que ele se apresente e sob qualquer aparência que a Razão lhe mostre. Mas, é nisso que é necessário que nos governemos hábil e eficazmente. É preciso fazer com ela o que uma Mãe faz com seu filho. Da mesma forma que, quando ela vê que ele leva sua mão sobre uma faca, ela tem o cuidado de afastá-la dele; e vendo que ele se obstina a querê-la, gritando e se atormentando por causa disso, ela a retira dali e coloca em seu lugar uma noz ou uma batata, acalmando-a definitivamente; assim também, quando nossa vontade concebe algum desígnio ruinoso, quando solicita coisas capazes de lhe fazer mal, quando leva sua mão sobre o gume da Fortuna, por assim dizer, é preciso afastá-lo dela, subtrai-lo e colocar um bem em seu lugar, para que, ligando-se a ele, ela se acalme e nos deixe em repouso. Mas, porque a aparência sob a qual a Razão lhe mostra o bem não é a que aparece no início, porque nunca descobrimos a verdade de uma só vez, e porque um antigo Filósofo teve razão de dizer que ela se esconde no fundo de um abismo ${ }^{70}$, é preciso que o Entendimento aplique todos os seus esforços no sentido de procurá-la, é preciso que ele penetre fundo nas coisas até ao ponto de encontrá-la; da mesma forma que os avaros, que vão buscar o ouro até ao centro da terra. Da mesma forma que eles se dedicam noite e dia por causa disso e não param nunca, enquanto não descobrirem alguma coisa, também é preciso que nos dediquemos até encontrarmos nada. Que felicidade e que riqueza é encontrar esse nada! Pois são apenas coisas que o vulgo estima tanto, eleva a um tão alto ponto e deseja tão apaixonadamente. Aprendamos, aqui, a nos servir utilmente de nossa liberdade. Usemos, da forma como se deve, das

\footnotetext{
${ }^{70}$ No original latino, Nieremberg se refere a Demócrito.
} 
luzes de nosso Entendimento. Façamos valer bem este instrumento tão nobre e tão capaz de operar nossa alegria. Que ele se empregue nisso e se dedique com todas as suas forças e com todas as ajudas que lhe vêm da Razão; que ele percorra Céu e terra para nos livrar, ou pelo menos, nos distrair de uma Opinião falsa e perigosa; e para nos persuadir de que aquilo que acreditamos ser um mal não o é. Será que sabemos que a memória das coisas duras e desagradáveis é, por si mesma, dura e desagradável? Elas são certamente mais cruéis do que aquela Serpente que traz seu veneno nos olhos, visto que ela só fere através da vista, enquanto que elas nos ferem com a nossa própria; elas se imprimem em nós, por nós mesmos; e se tornam o fatal instrumento de nossa infelicidade. Nisso, sem dúvida, elas são ainda piores, já que não ferem o corpo, mas o espírito; já que ofendem a parte que nos é mais sensível e difícil de curar; aquela parte na qual as menores chagas, sendo perigosas, se tornam facilmente incuráveis. Certamente, temos pouco cuidado com nosso repouso, ligando-nos à lembrança de coisas que nos inquietam e nos causam pena, afligindo-nos com pensamentos tristes e funestos, sem ousar nos distrair deles e transportar nosso espírito para além. Se nos acontece, alguma vez, de esclarecer e se dissiparem as nuvens que nos cobriam; se suspendemos nossa dor e eliminamos nossos problemas; tudo isso é apenas por um momento e, logo em seguida, voltamos a estar como estávamos. Como as crianças que persistem em querer brincar com o fogo, por mais que se queimem e não conseguem se impedir, de forma alguma, nem mesmo com o mal que dele recebem, de levar as mãos. No entanto, temos um meio bem presente e bem fácil para nos garantirmos contra a tristeza. Não consideremos as coisas desagradáveis, quando elas nos acontecerem; e não pensemos mais nela, depois que passarem. Não empreguemos tão mal a nossa memória, renovando a imagem dessas coisas. E se elas retornam, cuidemos que elas não nos causem nem terror nem espanto. É certo que quanto mais manipulamos uma ferida, tanto mais ela se envenena e cresce. De mesma forma que não somos tocados pelos males que não sabemos que nos vieram ao encontro, não sentiremos aqueles de que não nos lembramos mais; eles parecerão não terem acontecido, e nosso esquecimento produzirá o mesmo efeito que nossa ignorância. Sendo assim, não seria sinal de extrema fraqueza nos atormentarmos com as calamidades desta vida? Visto que o remédio é tão fácil de se empregar; e visto que, para nos defendermos, basta apenas não pensar nelas. Somos pouco razoáveis, quando temos tanta paixão e tanto ardor pelos bens; sobretudo quando eles têm em comum com os males o fato de só nos tocarem na medida em que são conhecidos, e quando podemos tão facilmente enganar o sentimento que eles nos dão. Por que é, para nós, tão difícil perdê-los, se, quando se trata de nossa felicidade, nos é indiferente tê-los ou não os ter? Se, não os possuindo, não deixamos de ser contentes? E, pelo contrário, os possuindo, não somos capazes de evitar a nossa miséria? Pensemos num avaro que perdeu seu tesouro, sem o saber; ele não deixará de se regozijar dele, imaginando ainda o ter; enquanto que, se lhe dissessem que ele não o possuísse mais, ele ficaria em desespero. Eu vos pergunto, quem mais, além da Opinião, produziria nele estes dois efeitos? Certamente, não é preciso outra prova para justificar que, assim como o mal que ignoramos não nos toca, aquele no qual não pensamos mais não é capaz de ser mais do que muito pouco sensível.

\section{QUARTO ENSINAMENTO}

\section{A observância da verdade}


Tudo o que acabamos de dizer é para aqueles que, não tendo a segurança para combater abertamente os males, devem recorrer ao artifício para evitá-los e que têm necessidade de compensar a falta de coragem com a habilidade. É certo que não seríamos capazes de ter cuidado suficiente na garantia contra a dor e a tristeza; não há nada que possamos fazer para nos defendermos das flechas de dois tão poderosos inimigos. É preciso, para isso, sem dúvida, um espírito firme e constante; que faça uma séria profissão de buscar, em todos os lugares e sempre, a verdade; que a proponha a si soberanamente; e cujo maior prazer, assim como a maior inclinação, seja abraçá-la e segui-la. Ora, antes de todas as coisas, ele deve saber que esta constância e esta firmeza só lhe podem vir da Razão. E é sobre este fundamento que se apoiou o Filósofo que disse que é preciso opor a coragem à Fortuna, a Lei à Natureza e a Razão às paixões ${ }^{71}$. E, para bem falar a verdade, quem poderia, eu vos pergunto, melhor acalmar as tempestades que a Fortuna excita do que um espírito resoluto, que nada é capaz de abalar? Quem ensina e melhor guarda a Justiça do que a Natureza? Por quem a inconstância e a impetuosidade das paixões são mais bem impedidas do que pela Razão? É dela que a Verdade tira o seu Ser. Ela vem do Céu, ela procede de Deus, sua primeira e natural Origem. A Opinião, pelo contrário, que a falsifica, que é como seu Macaco, que afeta e tenta se passar por ela, vem da terra, procede dos sentidos corrompidos, ela é filha do engano e da ignorância. Enquanto que a Verdade ecoa a excelência do lugar de onde saiu, é igual e imutável, faz com que aqueles que a amam não sejam inconstantes e diversos, mas sejam sempre iguais a si mesmos; a Opinião, pelo contrário, que sente a baixeza de seu nascimento, e que, por esta razão, é flutuante e incerta, comunica seu defeito a seus sectários e os torna, como ela, incertos e flutuantes. Aquela nos enche de alegria e exerce sobre nosso espírito o poder de um Rei legítimo; esta nos domina como um Tirano, nos enche de problemas e de confusão. A primeira caminha sozinha e não tem necessidade de um séquito para ser autorizada e para estabelecer o seu império; a outra tem um séquito insolente e tumultuoso, é acompanhada pelas paixões, assim como de outros satélites violentos e cruéis. Numa palavra, a Verdade é simples, é uma, é sempre a mesma. É por isso que dois grandes Santos a nomearam A Lei universal das Artes, a Arte do Operário todo-poderoso ${ }^{72}$. Ela é a guia fiel da Virtude, e regra infalível dos hábitos. Seus sentimentos são, em todos os lugares e sempre, iguais; ela é invariável em seus julgamentos e pensamentos. A Opinião, pelo contrário, está numa miserável e perpétua irresolução. Aquilo que, antes, ela aprovava, no presente ela condena; ela não se determina; ela é sempre diferente de si mesma. Se, portanto, queremos que nosso repouso tenha um fundamento sólido e firme, é preciso que o estabeleçamos sobre a Razão e sobre a Verdade. Só há uma porta através da qual ela entra em nós; mas há muitas através das quais a Opinião se introduz, ela se arrasta por inúmeras aberturas - por nossos sentidos, por nossa imaginação, por nossos desejos, por nossos apetites. Não apenas ela excita e remexe as paixões, como também ela concorda com elas em diversos assuntos, ela segue seus movimentos e, com elas, muda frequentemente. Disso é que vem o fato de que aqueles que ela possui, não estando de acordo consigo mesmos, são incapazes de o ser também com os outros. Isso, porém, não acontece àqueles que são governados pela Razão; porque, recebendo de uma única fonte e como que de um único canal, a luz da Verdade, não são distraídos por esta

\footnotetext{
${ }^{71}$ No original latino, Nieremberg cita nominalmente o filósofo Diógenes.

${ }^{72}$ No original latino, Nieremberg escreve: "Vere a divinis Augustino \& Prospero, dicitur lex omnium artium; \& ars omnipotentis Artificis”. Trata-se, portanto, de Santo Agostinho (354-430) e de São Próspero de Aquitânia (c. 390-c. 465).
} 
multidão de falsas imagens que a Opinião costuma formar, e que impedem o espírito de agir com clareza no discernimento das coisas. É por isso que se tem razão de dizer que todas as máximas verdadeiras são irmãs, já que são filhas de um mesmo Pai, porque vêm todas do Entendimento ${ }^{73}$. Assim é que, certamente, vemos as pessoas de bem e as razoáveis sempre conformes nos sentimentos e nos hábitos; enquanto que, ordinariamente, os outros são divididos e diversos, não conhecem a Verdade ou só a conhecem imperfeitamente, são semelhantes aos navios desgarrados durante uma noite obscura que não veem o Norte e não conseguem manter a rota direita. Com isso, podemos dizer que eles têm uma luz que permanece ofuscada, apagada pelas trevas da ignorância; uma luz que, sendo estendida sobre todas as ações de suas vidas, servindo como um véu espesso que lhes cobre os olhos, faz como que se choquem em todos os encontros e faz com que, como cegos miseráveis, tropecem incessantemente.

Assim, portanto, qualquer um que ame a paz e deseje adquirir o repouso, qualquer um que pretenda a felicidade, cuja rara vantagem é ser imutável e eterna, deve amar constantemente a Verdade, que é a base e o fundamento imóvel da felicidade. Nós aprendemos que ela se encontra na Razão, como sua fonte; na Razão purificada dos erros e, por assim dizer, do lixo e dos resíduos da Opinião. Esta Razão é a nobre e preciosa matéria de que é feita a Justiça e todas as outras Virtudes. Ela as produz e as mantém; ela é a sua Mãe e Nutridora. É um fogo divino que nos esclarece e que, conservando-se pura dentro de nós, é um penhor de nossa alegria muito mais nobre e certo do que, para os Romanos, era certa a duração de seu Império, aquele fogo sagrado que as Virgens guardavam com tanto cuidado. É preciso, por isso, buscar sem cessar a Verdade; tirá-la das coisas à força; abraçá-la, por assim dizer; adquiri-la, em seguida, de tal maneira que ela se torne um de nossos mais poderosos hábitos; que ela brilhe até nos nossos mínimos discursos; que ela os faça ser constantes e indubitáveis; e que ela dê também a nossos pensamentos a Veneração das coisas divinas. Disso, tiraremos a rara vantagem de que nossas palavras ordinárias terão a força e o peso dos juramentos; de que nossos conselhos serão escutados com o respeito que se tem aos Oráculos; de que nossos movimentos serão recebidos como se viessem do Céu. Mas, se acontece de sermos negligentes na prática de um tão grande bem, não o faremos impunemente, pois atrairemos para nós uma infinidade de males; sendo certo que a ciência que é sem ação, e que podemos dizer que é ociosa e morta, vale muito menos que a ignorância mesma. É por causa deste defeito que os Antigos Sábios infelizmente caíram na depravação notada pelo grande Apóstolo ${ }^{74}$. Ele disse: é por não ter colocado em ação seus conhecimentos que eles foram abandonados às paixões da ignomínia e a seus sentidos reprovados. É por isso que, não apenas não fazendo o bem, eles começaram a fazer também o mal; $e$ se encheram de iniquidade, de impureza, de avareza, de ociosidade; eles se tornaram operários da inveja e das calúnias; ficaram cheios de inveja, de homicídio, de engano, de fraude; eles eram caluniadores, orgulhosos, cheio de ódio a Deus, injuriosos contra o próximo, desobedientes de seus pais, sem amizade, sem franqueza, sem misericórdia. Consideremos, eu vos peço, em que abismo de males eles precipitaram, quando tornaram inúteis, por sua negligência, as luzes da Verdade que, para eles, se tornaram fracas e sombrias, de forma que toda verdade que pretendiam tirar do saber mais sublime seria incapaz de esclarecer verdadeiramente e seria incapaz de encher o espírito, senão de trevas e de confusão.

\footnotetext{
${ }^{73}$ No original latino, o autor se refere explicitamente a Proclo Lício (412-485).

${ }^{74}$ Trata-se de São Paulo.
}

193 Paulo Roberto de Andrada Pacheco. O terceiro livro do tratado De Arte Voluntatis ... 150-221. 
Como é possível que, nisso, não tendo nada que nos estimule o suficiente a sermos mentirosos, não façamos nada com mais liberdade e em maior quantidade do que mentir? Sentimos vergonha, ficamos incomodados por sermos chamados de enganadores; e no entanto enganamos com muita facilidade e, às vezes até - o que é ainda mais estranho -, sentimos um certo prazer em enganarmos a nós mesmos. Entre todos os homens que podem servir de motivo para atiçar nossa cólera, não há nenhum contra quem ela se excita e se inflama mais fortemente do que contra aqueles, sob uma aparência de franqueza e de sinceridade, brincam conosco e nos traem. Isso não podemos suportar e, normalmente, testemunhamos extremos ressentimentos. No entanto, ficamos felizes de brincar conosco mesmo e nos trairmos a nós mesmos. Temos consciência de sermos astutos e enganadores com os outros; mas não temos nenhum escrúpulo de o sermos conosco mesmos; não apenas suportamos isso, como também isso nos agrada; e nossa depravação vai até ao ponto de, nisso, encontrarmos até mesmo alguma delícia. Tão logo descobrimos a Verdade, e este belo Astro derrama seus raios sobre nós, levamos as mãos aos olhos. Nós os fechamos para não ver sua luz; amamos as trevas e sentimos prazer com a obscuridade; como aqueles pássaros infelizes que não suportam a claridade do dia $^{75}$; às vezes até, muito pior do que eles, visto que o fazemos voluntariamente e por desígnio, enquanto que eles o fazem por fragilidade e por impotência. Se, segundo nosso próprio sentimento, há infâmia em fazer calar a Verdade, por causa do temor que temos do suplício e da morte mesma, será que nos cremos honestos ao suprimi-la por causa de um respeito muito menor do que este? Ou seja, para adquirir as riquezas e as outras vantagens desta vida - que são passageiras e vãs -, e adquiri-las perdendo os bens do Céu - que são sólidos e permanentes, e que o amor e a prática da Verdade faz com que sejam infalíveis? Havia uma Lei entre os Egípcios que obrigava os estrangeiros a ir uma vez por ano diante do Magistrado, para declarar seus exercícios e suas atividades; e que condenava à morte aqueles que, nisso, fossem surpreendidos mentindo. Eles acreditavam criminoso e indigno da vida aquele que a fantasiasse e não falasse dela com fidelidade. Podemos pretender-nos inocentes, nós cujas vidas são uma fantasia e uma mentira perpétua? Nós que temos prazer em nos enganar para nos escusar de bem viver? De que serve nos adularmos, se somos criminosos e não abraçamos a Verdade? Sem dúvida, nos devemos propô-la como a soberana regra de nossos pensamentos e de nossas ações; como aquela a que todas as criaturas se reconhecem obrigadas naquilo que fazem; a quem elas não apenas devem o ser como também o bem ser. E como a devemos amar, visto que, através dela, atingimos o máximo da felicidade! Será que não teríamos nem amor nem sentimento algum por aquilo que toda a Terra confessa e publica? Por aquilo que o Céu mesmo reverencia? Por aquilo que atrai todas as graças e faz descer todas as bênçãos? Será que não teríamos respeito pela coisa do mundo que mais merece respeito? Aquela coisa, diante da qual, se dobram e se humilham os mais nobres e os mais sublimes? Abracemo-la, portanto, de todo o nosso coração; consagremos a ela todas as nossas afeições. Ou, se não somos capazes de um tão alto efeito, se não lhe podemos dar nosso amor, não façamos dela, pelo menos, o motivo de nosso ódio. Humilhemo-nos em sua presença e pareçamos, ao menos, tomados por um religioso e santo temor. Será que somos mais seguros do que o Céu, que estremece, que treme, diante dela?

\footnotetext{
${ }^{75}$ No original latino, Nieremberg cita as corujas e os gatos almiscarados, ambos animais de hábitos noturnos.
} 


\section{QUINTO ENSINAMENTO}

\section{Entrar em contato com o sentido da verdade}

Vimos acima como é que, de duas maneiras diferentes, o Entendimento peca em relação à Vontade: não lhe fazendo um fiel e justo relatório da condição das coisas; e lhe apresentando a Verdade sob imagens tão frágeis e lânguidas que, muito longe de tocá-la, não lhe causam a mínima emoção. O primeiro destes inconvenientes parece ser suficientemente reparado pelas máximas e pelas precauções de que fomos instruídos até aqui. Em seguida, nos dedicaremos a encontrar remédios para o outro. Sem dúvida, a indiferença e o peso com o qual o Entendimento age para lhe oferecer este último serviço, faz com que ele seja totalmente inútil. E, da mesma forma que um braço fraco e impotente não nos ajuda em nada, mesmo que ele não nos faça mal algum, também as Ideias que o Entendimento forma, por mais que não sejam falsas, são tão temerárias e tão pouco ativas, que a alma não se excita em nada e nem mesmo as ressente. São estes pensamentos que um Antigo nomeou muito apropriadamente de paralíticos e sem movimento, por causa do fato de elas não serem capazes de estender a mão para a Vontade, nem lhe dar a mínima assistência ${ }^{76}$. Assim, vê-se ordinariamente que uma verdade igualmente entendida e aprovada por duas pessoas, a uma excita até ao ponto de entrar profundamente em seu coração, enquanto que à outra apenas toca muito dificilmente. Eu vos pergunto, o que mais poderia causar esta diferença, se não fosse a languidez do Entendimento, que não toma como deveria esta Verdade, que não a anima, que não lhe dá nem calor nem força, e que, por sua moleza, impede sua eficácia? Sem dúvida, é preciso que o Entendimento esteja capacitado, no seu devido fundamento, na disposição necessária para recebê-la. É preciso que ele se coloque diante dela, que ele a acolha com alegria, que se torne capaz de seu efeito, que ele ajude suas operações. De outra forma, certamente as operações lhe serão inúteis e, por mais que ela seja a coisa mais forte e mais penetrante do mundo, não receberemos nem mesmo a mínima impressão. Aquilo que se nos diz nos toca as orelhas, mas não toca o nosso coração. Por mais presentes que estejamos a quem nos fala, pode-se dizer que não estamos diante dele; e mesmo que, de olhos fixos, com rosto sóbrio, com corpo firme e imóvel, façamos parecer que estamos atentos, não temos a mínima atenção; escutamos como quem não escuta. Quanto homens, eu vos pergunto, ouviram a Verdade mesma falar, quando ela veio sobre a Terra - que, para se comunicar a nós, assumiu um corpo mortal e se revestiu de nossa Naureza - e aprovaram-na, aplaudiram as exortações que fez de abandonar o mundo e, no entanto, permaneceram ligados ao mundo, não se desfizeram de suas honras e de seus bens e, pior ainda, não renunciaram a seus vícios? ${ }^{77}$ Houve outras a quem esta mesma Verdade persuadiu, entrou inteira no coração, se imprimiu

\footnotetext{
${ }^{76}$ No original latino, Nieremberg escreve: "Istae sunt cogitationes, quas egregie Alchuuinus paralytica dixit, sine motum sunt; nequeunt porrige voluntati manum; nequeunt gubernare lacertum". O "antigo" a que se refere o tradutor é Santo Alcuíno de Iorque (735-804), que é considerado o Patrono das universidades cristãs.

${ }^{77}$ Neste trecho, no original latino, Nieremberg cita alguns nomes: "Quot sunt, qui verissimum habuerunt, qui saepius audierunt, quod magnus Antonius, quod Simeon Stylita, quod Franciscus, subita sapientia: sed retinuerunt suas opes, \&, quod peius est, opera, vitia?”, que poderia ser traduzido da seguinte forma: "Quantos são aqueles que escutaram com muito verdadeiro, que muitas vezes escutaram aquilo que, com sabedoria, o grande Antônio, Simeão Estilita e Francisco disseram: mas mantiveram suas riquezas e o que é pior ainda, continuaram nas ações depravadas e nos vícios?”. Os três personagens citados são: Santo Antônio de Pádua (c. 1195-1231), São Simeão Estilita (c. 389-459) e São Francisco de Assis (1182-1226).
} 
vivamente em seu espírito. Mais uma vez eu vos pergunto, de onde é que pensamos que isso possa proceder, se não for do fato que nestes o Entendimento se agarrou à Verdade fortemente e com vigor, enquanto que naqueles ele agiu com covardia e negligência? Aquele insolente Rei do Egito que, por ter vencido quatro Reis, se tornou tão orgulhoso, para não dizer tão brutal, a ponto de não apenas tirar deles as prerrogativas e as marcas de sua grandeza, mas tirando-lhes também os privilégios da humanidade, impondo-lhes o jugo com o mesmo império que ele impunha aos animais, atrelando-os a seu carro de triunfo, terá, alguma vez, posto os olhos no movimento das rodas de seu carro? Ou seja, terá ele visto a mais natural imagem da instabilidade da Fortuna? Terá, alguma vez, considerada a Fortuna mesma, a ponto de entender que ela é inconstante e variável? No entanto, ele não fez sólidas reflexões, a ponto de, ao ver que um desses Reis olhava muito fixamente uma roda, e lhe tendo perguntado o motivo, ele achou que aquele Rei estava admirado com a velocidade com a qual ela girava, e ele achou que aquele Rei tirava prazer do ver como os raios da roda que estavam no alto, de repente, caiam e se encontravam embaixo; foi então que ele se deu conta dos dois estados da vida e começou a deplorar a inconstância das coisas do mundo. Foi então que este Príncipe soberbo, que nunca se havia deixado tocar por esse tipo de pensamento, abriu todo o seu espírito e, começando a temer para si a mudança que via no outro, começou a desconfiar da duração de sua felicidade, e começou a considerá-la suspeita de inconstância, e mudou o cativeiro desses Reis escravos numa condição suportável e doce, e começou a tratá-los com toda sorte de favores, daí em diante ${ }^{78}$. De onde vem o fato de que gritemos tão frequentemente contra a Fortuna, que nos lamentemos sem cessar dela, que digamos que ela só nos dá coisas do Mundo, que este brilho com o qual ela nos deslumbra é não apenas falso como também perigoso, que é um brilho fatal que nos conduz ao precipício? De onde vem que afirmemos isso tão seriamente, mas não sejamos persuadidos disso? É porque não penetramos no interior da verdade e só a vemos pelo lado de fora. Não conhecemos de forma alguma este nada sobre o qual falamos tão fortemente; caímos numa manifesta contradição; tornamo-nos ridículos ao dizer que a coisas do mundo não são nada, ao mesmo tempo em que corremos tão efusivamente para elas. Se, de verdade, acreditássemos nisso, nós as rejeitaríamos constantemente; elas seriam o contínuo objeto de nosso desprezo. Como é possível que aquilo que não é nada posso nos atrair tão poderosamente a ponto de reter o nosso coração? Esta força só pertence a Deus; sem dúvida, ela é própria apenas daquele que é todas as coisas. Será que poderíamos, aqui, admirar suficientemente, deplorar suficientemente a nossa loucura de fingir dizendo que os bens e as honras do mundo são um nada, mas ter a impudência de preferir este nada à Virtude? De preferi-lo à mais nobre e preciosa de todas as coisas? Somos impostores e não cremos no que dizemos. Temos, em nossa boca, muito excelentes propósitos, mas não os temos no coração. Pronunciamos salutares máximas, glorificamo-nos dizendo belas sentenças; mas não temos correta inteligência delas. A languidez de nosso Entendimento faz com que elas sejam inúteis e sem fruto. Solicitamos aos outros que façam o bem, nós os animamos com nossos discursos; mas não lhes mostramos o exemplo. Com isso, permanecemos na frieza e na preguiça, ignorando as coisas com as quais queremos lhes instruir. Somos como aquelas pessoas que falam enquanto dormem, que não conseguem se escutar e são escutadas por outros. Somos semelhantes a um instrumento musical que ninguém escuta o som que ele faz e, portanto, não causa prazer algum. Não consideramos que as aparências da Verdade só são conhecidas por nós pela casca, e nos enganamos de que ela esteja onde,

\footnotetext{
${ }^{78}$ No original latino, Nieremberg cita explicitamente o Rei Sesóstris, no entanto, não está claro a qual dos três reis com este nome se refere o autor.
} 
com efeito, ela não está. É por isso que não somos capazes de valorizá-la como realmente vale. Como nós não a vemos, ela não nos excita e não nos parece digna de ser amada. Quem olha apenas para o estojo onde se guardam pedrarias, julga bem que elas estejam dentro, mas não é capaz de estimá-las segundo seu verdadeiro valor. Nós paramos na superfície da Verdade; considerando apenas sua aparência agradável e brilhante; mas não a buscamos mais fundo; nós apenas a estimamos por seu estojo. Que certeza poderemos ter acerca dela com este tipo de estimação?

É preciso, portanto, apoiar fortemente os sentimentos que nos vêm da Verdade; e como eles são frios e lânguidos, por causa do pouco vigor que o Entendimento lhes dá, é preciso sustentá-los e, por assim dizer, nutri-los e aquecê-los, tendo por eles uma grande atenção e uma firme crença. É preciso ajudar a graça, estender-lhe a mão e acolhê-la, quando ela se comunica a nós. É preciso não apenas escutá-la, mas escutar o que ela diz; ouvir não apenas as palavras, mas compreender o seu sentido, recebê-las no coração; em seguida, fazê-las passar do coração às mãos, ou seja, colocá-las em prática e dar efeito ao que ela ordena. E, como quando alguém nos fala baixinho ou de longe, acudimos atentamente a nossa orelha e redobramos a nossa atenção, da mesma forma, quando acontece de se pronunciarem estas Verdades para nós, sem dúvida é preciso uma escuta tanto mais atenta, visto que nós as pronunciamos em baixo volume. É preciso empregar todo o nosso estudo para compreendê-las e retê-las. Ora, esta vantagem nos vem da Graça mesma, tão logo nós nos dispomos a recebê-la. Asseguremo-nos de que, por menor que seja o esforço que façamos para nos colocarmos diante dela e nos tornarmos capazes de recebê-la, ela se aproxima de nós, ela vem ao nosso encontro. E para possui-la inteiramente, nós só temos que não rejeitar os secretos movimentos que ela realiza em nós. Não é verdade que não tornaríamos público em alto e bom som uma verdade constante e que não seria razoavelmente contradita, que arruinando nossa cobiça nos permitiria estabelecer nosso repouso? Será que nos livraríamos de uma infame e cruel tirania que nos oprime? Não ouvimos dizer, agora mesmo, que o meio infalível para adquirir a paz do espírito é reprimindo nossas paixões; e que se somos os mestres, somos felizes; e também que nossa felicidade cresce na mesma medida em que a arrancam de nós? Certamente, não há nada que mais tenhamos à boca, mas não há nada também que menos tenhamos dentro do coração. Tão logo nos pronunciamos esta Verdade, não pensamos mais nela; temos nosso espírito em outro lugar, faltam-nos igualmente a atenção e a crença. Cegos e infelizes que somos! Por que, buscando com tanto cuidado a tranquilidade e a alegria, e não desejando nada com mais paixão do que chegar a isso, fazemos ao mesmo tempo todas as coisas capazes de nos privar disso? Por que, querendo nos tornar felizes, buscamos as honras e as riquezas que são manifestamente contrárias ao nosso desígnio, que se opõem ao nosso objetivo, e não apenas nos impedem de chegar à felicidade, como também nos precipitam na miséria? Dizemos que é preciso nos desfazer da ambição e da avareza, que é preciso apagar nossa cobiça e, no entanto, fazemos o possível e o impossível para mantê-la, dando-lhe material para que se reacenda. Certamente, nós nunca entendemos o sentido destas Verdades, nunca as compreendemos ou, pelo menos, nunca acreditamos nelas. Não nos persuadimos dos inconvenientes e das desordens que são causadas em nosso espírito quando nossas paixões estão desordenadas.

Além do mais, se não podemos descobrir plenamente o sentido da Verdade, é preciso que nós o aprendamos daqueles que o possuíram eminentemente, que adquiriram sua inteira e perfeita inteligência. Sem dúvida, eles no-la poderiam dar suficientemente através das palavras. Isso, se nos fosse suficiente tirá-la de suas bocas; 
mas nós a tiramos muito melhor ainda de suas obras; nós nos instruímos com muito mais certeza através de suas ações - mais do que por seus discursos. Como fazemos muitas coisas com o testemunho de outros, atuaremos certas Verdades a partir do relatório daqueles que, as tendo conhecido felizmente, as praticaram utilmente em seguida. Abraçaremos o bem os imitando e tendo fé neles. Aqueles que uma alta Sabedoria e uma eminente piedade são considerados por nós como luzes e ornamentos do mundo. Diremos: "Os Filósofos e os Santos fizeram assim, por que eu não deveria também fazer o mesmo? Foi por meio disso que eles atingiram o ápice da Virtude; foi por meio disso que eles ganharam o Céu. Se esta Verdade que lhes fez fazer grande coisas, coisas que admiramos, não for capaz de me excitar, certamente o seu exemplo o fará. Por mais ligado que eu seja a meus próprios sentidos, me sentirei forçado de abandoná-los para seguir o seu sentido; conformar-me-ei, apesar de mim, talvez até mesmo com pesar. Sem dúvida, seus efeitos prevalecerão sobre minhas persuasões, e serão levados até mesmo sobre meus sentimentos; servir-me-ão de regra, manter-me-ão ligado à lei, com a qual será necessário que eu concorde. Pensarei no fato que não foram poucas as coisas que concederam a estes excelentes homens a graça de tão sublimes pensamentos e lhes fez produzir ações tão extraordinárias. Será que eu não consigo ver o quão constante é esta Verdade, segundo a qual as riquezas e os outros dons da Fortuna são extremamente contrários ao repouso do espírito? Ou a Verdade segundo a qual elas são perigosas a quem as ama? Que muito frequentemente elas causam infelicidade e ruína em quem as abraça? Será que esta verdade não é suficientemente forte para me comover? Ela o será na medida em que eu tiver presente aquilo que ela faz acontecer àqueles que a conheceram plenamente e penetraram até ao seu centro. Só tenho que imitá-los e seguir o caminho que eles seguiram. Só tenho que fazer o que eles fizeram, se eu não me tiver proposto ultrapassá-los e fazer melhor do que eles”. Esta Verdade que não me excita e não é capaz de me levar ao desprezo das riquezas inspirou a muitos Sábios, que, para se privarem inteiramente das riquezas e perdê-la sem a menor esperança de reavê-las, lançaram-nas no mar. Acerca disso, pensemos no Filósofo Crates ${ }^{79}$ glorificando-se de haver evitado sua perda perdendo suas riquezas, e de se ter garantido de um naufrágio abandonando-as. Consideremos sua alegria por se haver livrado de um mau mestre como é o ouro, um mestre que mostra por seu falar e por seu rosto o mal que causa àqueles que o servem, e as contínuas apreensões que faz sofrer. Esta mesma Verdade fez com que Serapião ${ }^{80}$ largasse todos os seus bens; esta Verdade o despojou tão absolutamente que podemos mesmo dizer que ela praticamente o deixou nu. E eis o mestre de todos os bens; aquele a quem todas as coisas pertencem soberanamente; o Senhor da Terra e do Céu, que a Verdade tornou tão pobre que não teve nem mesmo onde repousar a cabeça. Depois disso, será que podemos duvidar dela? Que espírito não ficaria persuadido e não se deixaria impressionar por ela? Certamente, onde as provas são assim tão manifestas, é supérfluo alegar testemunhas. Nomeamos três ${ }^{81}$; mas nomearíamos trezentas, um número infinito. Eis como aquilo que não faríamos pela força da Razão, o fazemos pela força dos exemplos; eis como, por mais lânguido que seja o nosso Entendimento, os exemplos são fortes o suficiente para excitá-lo. Com isso, fica certo que, tão logo pensamos na virtude de outro, a imagem que se imprime em nosso espírito forma ali mesmo um secreto e salutar orgulho que nos

\footnotetext{
79 Trata-se de Crates de Tebas (c. 365 a.C.-c. 285 a.C.).

${ }^{80}$ Trata-se de Serapião Sindonita, monge egípcio que viveu no século IV.

${ }^{81}$ Crates de Tebas, Serapião Sindonita e Jesus Cristo,que não aparece nomeado, mas é referido - "Senhor do Céu e da Terra”, que não tinha "onde repousar a cabeça”.
} 
faz crer que não somente somos capazes de nos igualar a eles, como também somos capazes de ir além deles. Muitas vezes, imaginamos que somente com fortes considerações e razões muito poderosas é que conseguimos formar em grandes desígnios que nos dão admiração. Persuadimo-nos que nunca é por pouca coisa, que estes homens excelentes que nos propomos imitar, e que excitam nossa emulação, tiveram todos os cuidados e aplicaram todos os seus esforços para conseguir vencer nessas coisas. Podemos, muito mais, conseguir um notável socorro em nós mesmos, excitando em nós uma generosa resolução de fazer o bem, bastando para isso que nos deixemos governar pela Razão e tão logo ela tenha sobre nós a potência absoluta que ela deve ter. É preciso nos lembrar deste feliz movimento que nos levou à prática da Virtude; pegar emprestado de nossa memória o vigor que falta ao nosso Entendimento, e aquecer este último através daquela: "No passado, eu me deixei tocar por esta Verdade; fui capaz de ser tocado por suas impressões; ela me persuadiu; por que, agora, ela não me toca? Se, antes, eu a deixei agir, o que me impede de deixá-la agora? Se, antes, fui algumas vezes virtuoso, certamente posso ser ainda; posso me dedicar para o bem, posso me dedicar, até mesmo, com mais segurança de que conseguirei, com mais certeza de que sou, para mim mesmo, um exemplo; de que não é sobre a promessa de outros que eu construo, mas sobre minha própria fé”.

\section{OUTROS PRECEITOS CONTRA A OPINIÃO}

\section{PRIMEIRO PRECEITO}

\section{Premeditar os males}

Mas, seria inútil pretender conquistar a Verdade sem nunca chegar a ela, deixando imperfeita a ruína do Império da Opinião, sua perpétua inimiga, e não tendo todos os cuidados necessários para nos libertarmos de uma tão cruel servidão. Mais atrás, nós nos instruímos acerca dos meios infalíveis para nos livrarmos dos males que ela nos suscita. Podemos dizer que nossa cura está, de agora em diante, em nosso poder. Mas, como os remédios que se tomam em plena saúde por precaução e tão somente para se confirmar na saúde são mais agradáveis do que aqueles que são aplicados na doença, por necessidade; como o soldado só espera se armar quando está no campo de batalha e na presença do inimigo; e como é próprio de um sábio Capitão não dormir durante a trégua, mas se fortalecer e se munir de tudo o que lhe for necessário para se defender; também nós devemos empregar a pausa que recebemos da Fortuna para nos colocarmos em condições de tornar inúteis seus esforços que virão; pensando, durante o tempo em que ela nos tratar bem e nos acariciar, nos truques, nas injúrias que ela nos pode infringir; formando, durante a calmaria, a imagem da tempestade; preparando-nos e nos esforçando para a nossa salvação; da mesma maneira que quando ela está próxima, e como se estivéssemos a ponto de sermos atingidos por ela. Praticaremos, aqui, a máxima que um Sábio da Antiguidade nos deixou ${ }^{82}$ : premeditar cuidadosamente os males, persuadindo-nos de que eles são feitos para nós, bem como para o resto dos homens, crendo firmemente que não há mal algum que não possa nos atingir nesse exato momento. Se estivermos em viagem,

\footnotetext{
${ }^{82}$ No original latino, Nieremberg também não nomeia este “Sábio da Antiguidade”, apenas cita um longo trecho do referido autor que, no entanto, não foi identificado em obra alguma.
} 
preparemo-nos como se estivéssemos em nossa casa e, nisso, encontraremos alguns motivos de dor - o incêndio ou a ruína de nossa casa, a morte ou a doença de nossos filhos, a perda de nossos bens, a perda daquela querida pessoa em posse de quem nós nos consolávamos de nossas perdas; numa palavra, coloquemo-nos na condição de quem caiu numa dessas infelicidades. Perguntar-se-á, para que serviria isso? Que vantagem poderíamos esperar de um pensamento tão triste? Certamente este: que é muito interessante estarmos preparados para receber, sem incômodos maiores, todo tipo de acidente; preparados a não achar nada estranho ou novo, em meio às mais duras desgraças que possam nos atingir; vermo-nos felizmente enganados por outro evento que não imaginaríamos que poderia ter acontecido; e finalmente tomarmos como ganho tudo aquilo que virmos acontecer para além do que esperávamos que pudesse acontecer. São estas as vantagens que essa premeditação nos produzirá. Ela nos servirá de muralha contra os mais violentos assaltos da Fortuna; por este meio, nos tornaremos capazes de nos defendermos contra ela; e todos os males que ela no suscitar nos serão muito pouco sensíveis, porque já nos serão conhecidos antecipadamente. Assim, portanto, praticando felizmente esta precaução, não correndo o risco que correm aqueles que se deixam surpreender pelo inimigo e facilitam, por seu descuido, sua própria perda, teremos o cuidado em todos os nossos desígnios de considerar seriamente de onde podem derivar os maiores problemas. Praticaremos, nesse ponto, aquilo que se faz na guerra: enviaremos nossos pensamentos adiante de nós, para fazer um reconhecimento do campo inimigo; nos dedicaremos a descobrir os inconvenientes que podem nos atingir. A Fortuna é exata, é regular em sua inconstância e em suas mudanças. Sem dúvida, somos todos - em todo o mundo - sujeitos a isso. Quando ela quer fazer o bem, ela se propõe a poucas pessoas; mas, quando ela quer fazer o mal, ela tem todos os homens como alvo. Dediquemo-nos, portanto, cuidadosamente para nos garantir desses males nos quais sua malícia e sua ligeireza poderiam nos fazer cair; não sejamos tão frágeis a ponto de crer que ela nos isenta deles, ou que ela tenha por nós algum respeito que ela nunca teve por alguma pessoa. É preciso mais esperar os efeitos de sua ira; e para não os achar estranhos, é preciso tê-los por infalíveis. Se não vemos segurança naquilo que queremos empreender; se, pelo contrário, as dificuldades nos parecem extremas nesses casos; se o perigo é evidente; guardemo-nos de cometê-lo sem uma necessidade absoluta, e naqueles momentos em que não teremos nenhum lugar para nos defender. Pode haver loucura maior do que fundar a esperança de um feliz sucesso sobre a malignidade da Fortuna, abertamente declarada nossa inimiga? Somente aqueles que não são sábios ou que se entediam com a vida, embarcariam num navio que fizesse água por todos os lados e que estivesse visivelmente a ponto de ir a pique. Certamente, é estar fora de si colocar-se voluntariamente em perigo. É uma das coisas das quais Catão se acusava. Ele se arrependia de ter feito, por água, o caminho que ele poderia ter feito por terra. Quer dizer que é necessário, sempre, tomar o partido mais certo, e manter a rota mais segura. Sem dúvida, não devemos nos aventurar por caminhos em que não seríamos capazes de evitar o perigo; e não devemos crer que um perigo é menor porque alguém conseguiu, fortuitamente, escapar; mas tão somente se for necessário que nos exponhamos a ele. Ora, é suficiente para isso que tenhamos algum respeito pela Virtude, cuja consideração é a coisa mais forte que poderia tocar uma alma generosa; então, certamente, não precisamos temer nada e não temos motivo para perder a coragem. É preciso que ajamos, nesse caso, com resolução e alegria; mas com luz e conhecimento, não com movimentos cegos e com uma impetuosidade brutal como acontece com aqueles que se jogam num precipício. É preciso, seriamente, imaginar as infelicidades futuras, premeditá-las, considerá-las com uma vista tranquila e segura, a fim de nos formarmos o hábito de não as temer quando 
elas nos chegarem, e para que elas nos sejam menos formidáveis quando se nos apresentarem. Diz-se que a Leoa, defendendo seus filhotes contra aqueles que querem levá-los, olha fixamente as lanças com as quais a atacam; fixa seus olhos nelas para não ficar assustada. A Virtude é muito mais generosa: não apenas ela faz com que pousemos nossa vista firmemente sobre as infelicidades, e as consideremos sem incômodos, como também ela nos levanta o coração junto com a fronte, ela nos arma contra elas, ela nos dá a força para vencê-las, dando-nos a habilidade para prevê-las; ela nos faz mesmo ir à frente delas; e como ela está absolutamente fora do poder da Fortuna, e visto também que ela não teme suas mudanças e seus caprichos, ela espera com constância todas as coisas e tira esta vantagem de sua espera: não se admira por nada, nada que lhe aconteça surpreende ou é uma novidade. Qualquer um que tenha chegado a este ponto, pode se gloriar de ter atingido o cume da Sabedoria.

Além do mais, colheremos um duplo fruto desta premeditação. Ela nos dará o meio para nos protegermos das infelicidades e os afastará de nós; e se nos for necessário sofrê-las, ela nos fornecerá o bem de sofrê-las com paciência. Sabemos qual é o proveito que um Sábio da Grécia tirou do fato de ter previsto a fertilidade do ano ${ }^{83}$. Certamente, não é menor o proveito que vem da previsão da esterilidade da Fortuna, os poucos bens que temos que esperar e os espinhos que ela nos prepara. Nisso, encontraremos motivo para nos enriquecer muito mais do que aquele Filósofo. Com essa habilidade, adquiriremos o que há de mais precioso na vida, uma soberana tranquilidade. Assim como não é difícil evitar uma flecha quando a vemos chegar, sobretudo quando vem de longe, seremos capazes de nos garantir facilmente das afetações da Fortuna, quando as premeditarmos; não seremos ofendidos de forma alguma por elas, porque não seremos surpreendidos. Se for necessário que as infelicidades nos atinjam, ou se for impossível desviá-los de nós, pelo menos esta vantagem permanecerá conosco: tendo-as previsto, nós as enfraqueceremos. Da mesma forma que a água do mar se corrige e adoça passando pela terra, também é certo que, passando por nosso espírito, amassaremos a ponta de suas lanças e corrigiremos sua amargura. De onde vem, eu vos pergunto, que o tempo cura as dores mais violentas? Que ele seja o Médico dos mais duros incômodos? Que ele tenha remédios para os males que aparentemente parece não ter remédio? Sem dúvida é porque eles nos são sempre presentes, porque eles estão continuamente em nosso pensamento. Conhecemo-los, habituamo-nos a eles de forma que nos esquecemos o quão duros e terríveis eles são; nós nos acostumamos a eles; e a experiência explica por que não os sentimos mais, depois de os sentirmos por muito tempo. Assim como uma conversação muito livre diminui o respeito, também a familiaridade que temos com os males diminui em nós o respeito e arranca de nós a apreensão; e assim o uso faz em nós aquilo que a razão deveria fazer. A longa meditação é, para o Sábio, aquilo que o longo sofrimento é para o comum dos homens. Podemos pensar que o Sábio tenha sofrido os males sobre os quais ele tenha frequentemente pensado. Parece não apenas que ele tenha experimentado aqueles que poderiam lhe chegar, como também aqueles que podem chegar a outros; ele faz uma experiência geral, que o prepara para todo tipo de eventos, e de onde ele recolhe este excelente fruto que é o fato que, seja lá o que lhe acontecer, ele não achará nada infeliz e não se surpreenderá com nada. Ele disse: "Isso não me surpreende; este acidente, por mais infeliz que seja, encontrou-me pronto para recebê-lo; eu já o havia previsto há muito tempo; ele já estava em mim e não me chegou inopinadamente; eu não fiquei incomodado". Eis o quão rara é a vantagem que lhe vem de sua premeditação. E certamente os males nos parecem muito maiores quando eles não nos dão tempo para

\footnotetext{
${ }^{83}$ No original latino, Nieremberg cita Tales de Mileto (c. 624 a.C.-c. 558 a.C.).
} 
considerá-los, e quando somos atacados por eles antes de que estivéssemos na defensiva. Com isso, nossa dor cresce pelo lamento que advém de nossa imprevidência. Afligimonos ainda mais quando pensamos que nossa infelicidade é fruto de nossa falta, quando nos damos conta de que poderíamos nos ter protegido e que estava em nosso poder evitá-la. Sem dúvida, as mudanças repentinas não causam menos mal ao espírito do que ao corpo; ele sofre muito com os ataques imprevistos. A Soberana Sabedoria que concedeu uma tão maravilhosa ordem a todas as coisas, e a concedeu para o bem do homem, não achou bom que ele tenha passado de um contrário a outro, e que não houvesse distância entre o inverno e o verão - não saímos de uma só vez do rigor daquele para os ardores deste; somos preparados através da doçura da Primavera, como de um temperamento necessário, para que nossa saúde não seja incomodada. A premeditação dos males nos prepara da mesma forma para sofrer sua violência; e disso recolhemos esta rara vantagem de não tomar por uma desgraça particular e que só acontece a nós aquilo que vemos acontecer a todos, e que sabemos ser infalível para a condição humana. Somos instruídos, através disso, a não ter por insuportável aquilo que muitas pessoas sofrem, e que é certo que todos os homens, indiferentemente, podem sofrer.

Agora, ser-nos-á fácil responder ao Filósofo que achava pouco razoável a máxima sobre a premeditação dos males ${ }^{84}$. Justificaremos muito facilmente que a objeção com a qual ele pretendia combater essa máxima era frágil e ela mesma pouco razoável. Ele dizia: representar em si os males quando eles ainda não existem, sem dúvida é fazê-los chegar mais cedo, é precipitar a sua chegada. Não somente esta premeditação não nos traz vantagem alguma, como também nos causa pena; ela faz com que soframos antes que nos seja necessário sofrer. E, como se já não fosse suficiente o mal que nos atinge, nós ainda suscitamos em nós mesmos um novo; fazemonos infelizes antes do tempo; antecipamos nossa miséria através de nosso pensamento. Será que não nos é suficiente ter problemas com a incapacidade de nos defendermos do mal quando ele chega contra a nossa vontade, e ainda termos que nos atormentar sem necessidade alguma? Será que nossos cuidados não seriam mais felizmente empregados se nos dedicássemos ao menos a diminuir nossa dor, ao invés de nos tornarmos engenhosos no trabalho de fazê-la crescer? O que diremos nós depois de termos ouvido este Filósofo, que nos aconselha a fechar nosso espírito às imaginações tristes e incômodas, e que quer que o tenhamos leve e livre de dores e de tristezas, e que arranquemos dele tudo o que possa lhe causar isso? Não apenas ele não aprova esta premeditação, como também ele a rejeita fundado no fato que, segundo ele, estaríamos, assim, continuamente com problemas, e poderíamos acabar nos resolvendo a nunca saborear a alegria, se fosse realmente necessário que tivéssemos no espírito, incessantemente, a Ideia das infelicidades que nos podem chegar. Certamente, os males são suficientemente sensíveis quando estão presentes. A amargura, que é inseparável de todos os males, quando eles estão presentes, nos é muito incômoda, sem que precisemos pensar nela antecipadamente e nos atormentemos fora de época. Se o mal não nos chegar de forma alguma, quão grande terá sido a nossa pena de nos termos atormentado sem necessidade? Quanta dor verdadeira sentiremos por termos sentido uma dor falsa e sofrido tão inutilmente? Eu vos pergunto, para que nos afligir sempre e nos condenarmos a uma perpétua miséria, seja pelo necessário sofrimento dos males, seja por esta importuna e cruel premeditação? Estes dois Filósofos pretendiam, assim,

\footnotetext{
${ }^{84}$ No original latino, Nieremberg cita nominalmente o filósofo Simplício da Cilícia (c. 490-c. 560), que era neoplatônico.
} 
convencer acerca do erro dessa máxima ${ }^{85}$; mas, evidentemente, eles não se convenceram a si mesmos ao não considerarem que há muita diferença entre representar os males dentro de si, na preocupação e no incômodo do Entendimento e pintá-los de capricho e fragilidade para sentir medo deles, e representá-los com um espírito firme e tranquilo, para estudá-los e conhecê-los; de forma que seja possível se determinar firmemente a crer e saber verdadeiramente se são males ou não. Nisso, esta premeditação é excelente, visto ser por meio dela que fazemos este estudo e desmascaramos as coisas, arrancando delas esta aparência terrível que nós as fazemos ter. Assim, não apenas não se trata de fazer crescer o número dos males que é necessário que soframos, mas é diminuí-los muito, é colocarmo-nos em uma situação tal que não nos permita sermos surpreendidos pelas imposturas da Opinião que, ordinariamente, nos alarma falsamente e oferece-nos matéria de temor onde só deveria haver motivo de desprezo. Numa palavra, trata-se de evitar felizmente todo o incômodo e toda a pena que ela nos suscita. Premeditando desta maneira os males, tornamos infalível uma ou outra dessas vantagens, quais sejam: não encontrá-los onde imaginamos que poderiam estar e, se eles aí estão efetivamente e se é impossível nos defendermos deles, que pelo menos só sejamos atingidos levemente por eles. Dessa forma, nós os amolecemos na medida em que os consideramos; corrigimos sua amargura e enfraquecemos sua Violência. O que sabemos nós se o cuidado de estudá-los nos trará alguma daquela alegria de nos protegermos deles? Ou alguma habilidade para isso? Mas, se fossemos tão infelizes a ponto de que esta premeditação nos fosse inútil; se não pudéssemos nem evitar nem diminuir os males, então, certamente, haveria motivo para escutar o aviso do último desses dois Filósofos, que nos aconselhava a desviar nosso espírito dos pensamentos tristes e incômodos, visto que não nos virá outro fruto da premeditação de nossa miséria além da antecipação dela e do crescimento de nossa dor. Sem dúvida, é importante que aqueles que ainda não adquiriram a glória de uma constância experimentada contra os assaltos da Fortuna, não parem seu pensamento sobre os males presentes ou sobre os passados; sobre as chagas que sangram ainda e que ainda não cicatrizaram; para que uma muito grande apreensão de sucumbir ante os ataques desta poderosa inimiga não as faça desconfiar de suas próprias forças, quando ele vierem ao nosso encontro junto com a Fortuna; e não as desencoraje da prática do excelente remédio que nós lhes preparamos para encontrar os males menos rudes e menos excitantes. Será suficiente que algumas vezes eles se proponham aqueles que lhes podem chegar; para que, como os novos soldados que se endurecem nas ocasiões menos perigosas, eles adquiram pouco a pouco essa coragem e essa firmeza necessárias para os grandes combates. Fique certo, portanto, que é indubitável que considerar sem medo os males é desarmá-los, é aniquilá-los. Da mesma forma que ver uma flecha vindo de longe é conseguir evitá-la facilmente; assim também será como que tornar leve a ferida e fazer com que não seja mortal.

Portanto, é preciso premeditar os males, tanto para que não nos deixemos surpreender pela aparência daqueles que o Entendimento, seduzido pela Opinião, nos apresenta, quanto para nos prepararmos para receber os outros sem incômodo e não ficarmos assustados quando eles chegarem a nós. É preciso tratá-los com os eventos humanos, e fazer um pacto com eles para a segurança de nossa alegria, para que ela não seja alterada em nada; tê-los perpetuamente presentes ao espírito, meditar sobre eles seriamente, e nos mantermos sempre muito bem preparados para recebê-los. Escutemos, a

\footnotetext{
${ }^{85}$ No original latino, Nieremberg cita também o filósofo Epicuro, e estranhamente o tradutor não faz referência a ele até a este ponto do texto.
} 
este respeito, os Estoicos, que são os mais capazes para nos aconselhar a este respeito e nos conferir salutares habilidades: "Seja lá o que fizermos, é preciso examinar sempre com muita atenção, estudar cuidadosamente as consequências e as circunstâncias. Meditamos sobre uma viagem? Pensemos na pena e nos perigos que, ordinariamente, acompanham tais empreendimentos; coloquemo-los todos diante dos olhos; os incômodos e as fadigas que poderemos sofrer no caminho. E, quando algum deles nos chegar, digamos dentro de nós mesmos: eu não fui surpreendido de forma alguma com este encontro; por mais incômodo que ele seja, não atrapalha a tranquilidade de meu espírito. Quero conservá-la em meio aos mais desconhecidos acidentes; isso é o que eu me proponho soberanamente onde quer que eu esteja; é o objeto principal para o qual estou sempre visando; só me afastarei dele se sentir desgosto diante daquilo que me acontecer; não realizarei minha intenção apenas se me deixar levar pela impaciência e pela cólera”. Não há nada, até mesmo as ações particulares e menos importantes, em que esta precaução não deva ser absolutamente guardada, e na qual não sejam necessárias paciência e firmeza. Para isso, nos ajudará maravilhosamente, sem dúvida, o cuidado que tomamos em nos instruirmos acerca da condição das coisas nas quais ligamos a nossa afeição e que servem para o nosso prazer. Nós nos lembraremos que não há nada que dure muito, não há nada que não decaia ou que não pereça. Se amamos um vaso de cristal ou de barro, pensemos que ele é feito de uma matéria muito frágil; e será sem dor, ou pelo menos sem surpresa, que nós o veremos quebrado. Amando nossos parentes e nossos amigos, pensemos que tudo aquilo que teve um começo e que nasceu, deve ter um fim, deve morrer; é uma lei e uma necessidade, que não têm nem exceção nem dispensa. Aquele Filósofo a quem foram dizer que seu filho havia morrido soube muito bem colocar esta regra em prática ${ }^{86}$. Ele não se afligiu em nada, não lançou nem suspiros nem lágrimas. Ele apenas disse: eu já sabia que ele havia sido concebido como um mortal. Esta mesma consideração manteve a constância de muitos homens excelentes em situações semelhantes ${ }^{87}$. Foi esta mesma consideração que os armou e os fortaleceu contra a dor que poderia lhes ser dada pela perda de seus filhos e de outras pessoas que lhes eram caras. Eles não precisaram de nenhuma advertência para saber que Deus, que dá a vida, pode tirá-la quando bem entender; da mesma forma que uma pessoa que empresta algo tem o direito de retomá-la todas as vezes que bem lhe parecer. Eles não se pegaram nem com o Céu nem com a Natureza, pois sabiam muito bem que nem um nem outra eram culpados por aquilo que os fazia sofrer; sabiam que não há motivo para imputar a eles a causa de nossa dor; mas que se deve imputar tão somente a nós mesmos, que vivemos no esquecimento e na ignorância daquilo que somos, que nos entretemos com uma imaginação vã de não sermos sujeitos à fatalidade da tumba. Assim, nossa credulidade nos engana e nos trai; somos atingidos antes mesmo que pensemos sê-lo. Certamente, ignorar que somos enfermos e mortais é uma grande loucura não se lembrar, ou nem sequer pensar nisso, é uma extrema fraqueza; mas, trata-se de uma impudência insuportável nos incomodar com isso e nos pegarmos com quem nos fez isso. Outro grande personagem levou seu pensamento ainda mais longe do que o pensamento desse Filósofo e o encheu com sua sabedoria ${ }^{88}$. Como lhe disseram que seu filho havia morrido,

\footnotetext{
${ }^{86}$ No original latino, Nieremberg cita nominalmente o filósofo Anáxagoras (c. 500 a.C.-428 a.C.), afirmando que este filósofo, com este evento, comprovava o que fora dito por Epícteto (55-135) e por Eurípedes (c. 485 a.C.-406 a.C.).

${ }^{87}$ No original latino, Nieremberg cita: Péricles (c. 495 a.C.-429 a.C.), Marco Calpúrnio Bíbulo (?-48 a.C.), Quinto Fábio Máximo (?-45 a.C.) e Lúcio Emílio Paulo (?-216 a.C.).

${ }^{88}$ No original latino, Nieremberg cita nominalmente o filósofo Xenofonte (c. 431 a.C.-354 a.C.).
} 
ele tirou de sua cabeça a coroa de Sacrificador. Mas, como lhe disseram que ele havia morrido valentemente numa bela ocasião na guerra, tendo se enchido de honra, ele a retomou e não somente testemunhou consolação, mas também alegria; e a testemunhou com muito mais justiça, pois, com isso, dizia que não havia nascido apenas para viver, mas para viver com honra e adquirir glória; por isso, havia colocado no mundo filhos e, por isso, ele entendia que havia atingido seu objetivo e havia possuído seu desejo.

Desta maneira, o Sábio sempre tem aquilo de que precisa, e não se encontra nunca fora de seu objetivo; e nada de imprevisto lhe acontece, nada de inopinado, nada que o incomode e que seja capaz de lhe fazer perder sua alegria. Assim, o que quer que ele faça ou deseje, ele sempre o faz certo que nada nem ninguém está isento do poder da Fortuna; e, às vezes, ele chega mesmo a ter um certo respeito e reverência por ela; apesar de sempre a desprezar e não se ocupar em nada dela; ele não empreende nada nem nada estabelece baseado na confiança que o comum dos homens costuma ter. Ele lhe submete o sucesso de todas as suas esperanças, e todos os que se promete o faz com a condição de que ela não entrará em seu caminho e que ela consentirá. Ele se reconhece sujeito, da mesma maneira que no menor do povo, aos eventos humanos; mas ele não é, porém, infectado pelos erros do povo. Todas as coisas lhe chegam segundo a forma como ele as premeditou; e ele as premeditou da mesma maneira como elas lhe chegam. Ele deseja que elas passem da mesma forma como chegaram; ele as vê passarem como ele quis que elas passassem. Por mais que ele seja completamente decepcionado acerca do efeito de sua expectativa, ele sempre a realiza de alguma forma; tanto é assim que ele nunca coloca em dúvida que ele pudesse ser decepcionado, que sua expectativa pudesse ser enganada, que ele encontrasse obstáculo para a realização de seus desejos. Assim, pela segurança que ele tem acerca das malícias ordinárias da Fortuna, ele sempre as prevê todas, ele as torna impotentes pela previsão; ele só atingido levemente pelo lamento de ver suas esperanças vãs; porque ele nunca se apoiou nelas fortemente, a ponto de crer que elas seriam capazes de sustentá-lo; ele nunca apoiou nelas seus desejos, por mais leves e sem fundamentos que fossem, pois sabia que eles sempre se tornariam fumaça. Ele não ignora que não há nada que se possa esperar da Fortuna, além de sua malignidade e de sua inconstância; ele sabia que era errado pensar que aquilo que ele desejava aconteceria infalivelmente. Como, pelo contrário, ele sempre se desafiou quanto a isso; como seus desejos sempre foram modestos e moderados; como eles sempre foram tímidos e vergonhosos; ele não se surpreendeu de forma alguma com o fato de que eles não tenham sido respondidos; e só ficou um pouco tocado por isso; assim como ficaria muito pouco tocado se aquilo que ele tivesse prometido a si tivesse acontecido. Certamente, ele sempre será muito pouco enganado em sua expectativa; mas nunca será enganado no conhecimento que tem acerca das ligeirezas da Fortuna e do prazer que parece que ela tem em contrariar nossas expectativas, e zombar de nossas pretensões, e arruinar completamente nossas esperanças e nossos desejos.

\section{SEGUNDO PRECEITO}

\section{Esperar os males}

Mas, além daqueles males que procedem das ações e das coisas, que são os elementos de fixação e de consequência dos males - uns não devem nunca ser motivo de apreensão, porque são inevitáveis; os outros devem sempre ser esperados, porque sua 
vinda é incerta; de outra forma, nossa miséria nunca teria fim, ou seria pelo menos tão grande que ultrapassaria nossas forças e nos seriam insuportáveis; visto que as primeiras nos fariam sofrer um temor perpétuo e as outras, vindo as nos surpreender, nos seriam muito sensíveis e amargas -, é preciso abrir cuidadosamente os olhos sobre tudo o que a Fortuna pode praticar para nos causar pena; é preciso pensar nos dardos mais perigosos de que ele pode se servir. Certamente, pensar que alguém se possa prometer bens maiores do que males é próprio de um espírito mais imprudente do que ousado, mais temerário do que resoluto. Não é próprio de um homem são imaginar que os primeiros sejam em maior número que os outros. A quem a experiência cotidiana já não mostrou justamente o contrário? Será que não sabemos que nos vêm calamidades e desgraças de todos os lados? Será que não sabemos que, sendo, como são, em tão grande número e de tal forma propagadas, a ponto de podermos dizer que a Terra é toda coberta delas, não é de se maravilhar que nós as encontremos em todos os lugares e que elas nos atinjam a todo o momento? Sem dúvida, é preciso esperar, de modo geral, todos os males; não esperar ser isento de algum; às vezes, até mesmo, esperar tudo o que ultrapassa o poder e o uso da Fortuna. Pois bem, seremos enganados em nossa expectativa; os males que havíamos esperado não nos chegarão nunca. Não temos nunca dúvida alguma sobre aquelas aparências que nos causam desprazer; ninguém acredita que nos incomoda anular do estado de misérias de nossa vida aquelas misérias que não sofremos e possivelmente também as maiores que deveríamos ainda sofrer. Eu vos pergunto, o que perdemos por não ter deixado perdido o que pensamos haver perdido? Será que isso não é um proveito? Será que não conseguirmos repouso e alegria? É próprio de um espírito firme e constante estar preparado para toda sorte de maus encontros; ele deve imaginar sempre que não há nada de tão estranho que não tenha sido feito para ele, e que não possa lhe acontecer. Por mais prontamente que a má Fortuna ataque e por mais repentina que seja a aflição causada, ele a acusará, se não for de fragilidade e de covardia, pelo menos de lentidão e de preguiça. Esperando-a desta maneira, prever-se-á felizmente a sua chegada e ela não suscitará nenhuma infelicidade a quem chegar a dizer: "Chegastes bem tarde; esperei-vos por muito tempo; eu vos recebo sem incômodos; como foi sem temor que eu vos vi chegar”.

Foi por meio desta vantagem que aquele entre todos os homens que mais sofreu ${ }^{89}$, sofreu tudo com muita constância e mereceu ser eternamente proposto como um perfeito modelo de paciência. Por mais que seus males lhe viessem muito repentinamente e muito de uma vez, de forma que ele quase não havia um momento de intervalo entre um e outro, eles eram, para ele, lentos e preguiçosos; achava-os tardios, visto que ele os esperava há muito tempo, visto que ele estava preparado desde o princípio, e visto que ele já os havia sofrido com antecedência. E, para falar bem a verdade, nisso ele foi admirável e fez parecer uma alta resolução, e meio a uma profunda miséria; quando à perda de todos os seus bens juntou-se uma infelicidade infinitamente mais sensível e que, normalmente, faz com o que o comum dos homens sinta como a última provação - a morte de todos os seus filhos -; quando num só instante ele se viu despojado de todas as coisas; quando ele foi colocado completamente a nu, como que para nadar no sangue que uma chaga universal fazia escorrer de seu corpo; ou quando, em meio a prosperidades, num estado de felicidade e de florescimento, tudo isso parece não ter mais fim, e então os mais prudentes e aqueles que se seguram o mínimo possível nas coisas do mundo que estão menos estabelecidas julgam que a ruína seja impossível e que podem desqualificá-la e que não serão acolhidos por tantas e tão repentinas desgraças; ele, pelo contrário, se persuadiu

\footnotetext{
${ }^{89}$ No original latino, Nieremberg cita Jó.
} 
daquelas que a mais célebre miséria não havia ainda conhecido e sobre cujo rigor extremado da Fortuna parecia não poder ser notificado. No cume de bens e honras no qual ele se encontrava, ele formava para si mesmo imagens das calamidades nas quais ele poderia cair; a imensidade de vantagens que a Fortuna lhe havia conferido não o impedia de se representar os males infinitos que ela lhe poderia causar. Que proveito acreditamos que possa vir deste pensamento? Certamente, este, que é incomparável: receber, com um espírito tranquilo e sem nenhuma surpresa, aquilo que desespera o comum dos homens, aquilo que desconcerta os sábios, aquilo que arranca o coração dos mais resolutos, aquilo que abate, ou pelo menos abala, os mais constantes. Esta expectativa pelos males lhe trouxe esse bem maravilhoso: por mais estranha que fosse a mudança de sua condição, ele a recebia sem incômodos, ele não mudava seu rosto. Não nos surpreendamos com isso. Sua contenção, ou para melhor dizer, sua timidez na boa Fortuna, construiu a sua coragem na má Fortuna. Como ele sempre havia sido desafiado por aquela, ele não foi surpreendido por esta; ele não a recebeu, porque sempre havia recebido a outra; nada lhe aconteceu que ele não tenha sempre crido lhe poder acontecer e que ele não estivesse esperando que acontecesse. Ele dizia: se qualquer resolução igualmente estranha $e$ imprevista faz com que eu desça desse nível que fez com que eu conseguisse o respeito e a obediência de um tão grande povo; se aquilo que fortalece minha grandeza e minha autoridade, minhas riquezas, fosse levado embora; se acontece que eu seja despojado dessas coisas de alguma outra maneira; se esta incontável quantidade de ovelhas que cobrem os campos se perdesse e morresse toda de uma só vez; se o fogo do Céu caísse sobre elas e as devorasse todas juntas, além do ovil e dos pastores; se esse fogo reduzisse a cinzas as minhas casas, ou se um tremor de terra fizesse delas ruínas deploráveis; se o apoio de minhas esperanças e de minha alegria, meus filhos, fossem enterrados; se um dilúvio de males, vindo a se derramar sobre mim, envolvesse com minha fortuna a minha pessoa mesma; se eu sofresse e fosse atingido por dores insuportáveis; se fosse necessário que eu bebesse essa amargura em várias goles e diversas vezes, mas de uma só vez e no mesmo fôlego; se essas desgraças me chegassem todas de uma só vez e em menos tempo do que eu pudesse imaginar; tendo perdido tudo, até mesmo aquilo que pudesse cobrir a nudez do meu corpo, e ele ficasse exposto a todas as injúrias do ar; não tendo mais onde ficar, tenha que procurar moradia num sepulcro e me enterrar em vida; ou que me faltando até mesmo um sepulcro, seja obrigado a ir me esconder numa gruta ou até mesmo em alguma fossa; que, de então em diante, toda a minha família fosse como os vermes que se alojam em minhas entranhas; que ainda vivo eu fosse roído e assim a ordem da Natureza mudasse para mim e ela fosse, para mim, não menos inimiga e cruel do que a Fortuna; que todas as coisas me fizesse faltar e que até eu mesmo faltasse a mim; que, depois de tudo isso, eu não recebesse nem apoio nem consolação daqueles de quem eu mais deveria esperar receber; mas que eu fosse oprimido por suas censuras $e$ suas injúrias, e me tornasse o refugo e o objeto de desprezo; o que seria, no entanto? Eu não cairei em desordem; eu não perderei em nada a tranquilidade de meu espírito; nada acontecerá que me surpreenda ou que eu já não esteja esperando, não somente todos os dias, mas todas as horas, todos os momentos; eu estarei firme em meio aos mais rudes ataques da Fortuna; conservando a vantagem de não sucumbir a minhas infelicidades, conservarei o que vale mais do que minha grandeza e minhas riquezas; serei poderoso $e$ feliz, não sendo mais nem um nem outro; não serei menos satisfeito em meio à minha extrema miséria do que eu seria se estivesse em meio ao máximo de minhas prosperidades. Eis quais eram as meditações desse Herói; eis de que maneira ele se preparava e se fortalecia contra a má Fortuna. Ao mesmo tempo que ela derramava sobre ele todos os seus bens, que ela o acariciava o mais ternamente que lhe é possível, e que 
ela o carregava como que entre seus braços, ele a repreendia dentro de si e mantinha o pé em sua garganta; ele a considerava, ele a tratava como inimiga mortal, enquanto ela o tratava como amante e favorito. E da mesma forma que os valentes Capitães formam, durante a paz, uma imagem em si da guerra, praticam os torneios e outros exercícios que a representam; Jó também, figurando para si os males que lhe poderiam chegar e os esperando a qualquer momento, se preparava contra eles e estudava, em meio a maior de suas felicidades, as formas para combater e vencer sua miséria. Será que poderíamos desejar um exemplo mais digno para nos excitar na prática desta máxima tão salutar? Aprendamos de Jó a arte de suportar com um espírito firme e igual, as desigualdades da Fortuna. Quando nós a tivermos propícia, esperemos a rigorosa. Suas mudanças não nos surpreenderão e não nos causarão mal algum. A adversidade que se espera não é mais adversidade quando ela chega; ela perde tudo o que tinha de mais duro, não tem mais nem rudez nem acidez.

O soldado, em meio à guerra, o que mais espera além das feridas? $\mathrm{O}$ que mais poderia esperar além de golpes, um Atleta que está no liceu? Mas, as Armadas escaramuçam antes de se encontrarem no campo de batalha; elas fazem como que ensaios de suas forças antes de combaterem seriamente. Não se tira da bainha a espada que não se sabe usar; não se vai ao campo, se antes não se esteve nos lugares de esgrima. A Fortuna é uma poderosa e perigosa adversária contra a qual devemos combater; temos que esperar dela apenas feridas; mas, antes de entrar no combate com ela, é preciso que aprendamos a nos defender de seus golpes, é preciso que saibamos a forma de nos desviarmos e de nos defendermos. Um Ateniense tendo que se bater num duelo contra um Coríntio, e que se cria muito inferior em força e em habilidade ao rival, pintou-o para si mesmo tão furioso que parecia que ele nunca poderia dar conta. Quando eles se apresentaram um ao outro, vendo-o muito menos terrível em pessoa do que havia pintado, e muito inferior àquilo que ele se havia figurado do rival, ele não teve nenhuma apreensão e se tornou corajoso até ao ponto de não ter dificuldade alguma para vencê-lo ${ }^{90}$. Outro, não podendo se persuadir de ir à guerra, porque havia pensado nos perigos tão grandes e tão frequentes da guerra, a ponto de imaginar que sempre se morre na guerra e que toda e qualquer flechada derruba todo e qualquer homem, tendo se desenganado através de uma experiência contrária, tirou esta vantagem de seu erro: se não a vantagem de desprezar o perigo, pelo menos a de não o temer $^{91}$. Devemos pintar a Fortuna para nós da forma mais furiosa e temível que ela possa ser, para que não nos assustemos com ela quando se apresentar diante de nós, e para que adquiramos a coragem através da diferença que encontraremos entre aquilo que pensamos e aquilo que ela é verdadeiramente. Da mesma forma como acontece na prática que temos com os animais mais selvagens, a verdade é que, lidando com eles, eles se tornam tratáveis e familiares. Da mesma forma acontece com o objeto mais desagradável e hediondo: ele deixa de sê-lo e não nos dá mais medo quando nós o temos frequentemente diante da vista. Não teremos medo algum dos males que uma séria premeditação nos tiver frequentemente representado. Sem dúvida, aquilo que eles têm de terrível, não o é; eles o retiram de nossa Opinião; é somente ela que lhes dá esta aparência e esta máscara que nos assusta ${ }^{92}$. A armada do último Rei da Macedônia que foi vencida e levada em triunfo pelos Romanos,

\footnotetext{
90 No original latino, Nieremberg não refere esse fato.

91 Também esse exemplo não consta do original latino.

92 No original latino, Nieremberg termina essa argumentação dizendo: "Hanc merito Lamiam vocavit Socrates”, que poderia ser traduzido assim: “esta mereceu ser chamada, por Sócrates, de Lâmia”. Trata-se de uma referência a um monstro da mitologia grega, que tem bela aparência, mas ataca os jovens e lhes suga o sangue.
} 
perdeu inteiramente a coragem à vista de uma grande obscuridade que cobriu repentinamente o Céu e fez como que uma noite em pleno dia ${ }^{93}$. Os Romanos, pelo contrário, que já haviam sido avisados por seu Capitão da causa desse efeito, que era apenas uma falta da luz do Sol por causa da interposição da Lua entre ele e a Terra, não somente não se alarmaram, mas souberam muito bem fazer bom uso dessa situação. Por um acidente semelhante, e por uma ignorância semelhante acerca da causa que o produzia, a Armada de Nícias $^{94}$, um dos maiores homens da Grécia, tendo se assustado e fugido, obscureceu e eclipsou a glória desse Capitão. Certamente, como o favor da Fortuna desaparece e se esconde repentinamente; como ela tem suas falhas e seus eclipses, não nos será menos vantajoso preveni-los, como o é para os Astrólogos que preveem os eclipses do Sol. E quando nós os virmos acontecer, não nos surpreenderemos e não cairemos em desordem.

\section{TERCEIRO PRECEITO}

\section{Não inventar os temores}

Mas, é preciso sobretudo tomar bastante cuidado para que esta previdência dos males que nós recomendamos tão expressamente, e que é um soberano antídoto, proceda da reta persuasão do Entendimento e não de seu erro; que ela venha da razão pura e sã e não da imaginação desordenada e corrompida. Sem dúvida, há diferença entre o que é e o que somente parece ser; entre a verdade e a mentira. É preciso exatamente premeditar tudo aquilo que a Fortuna tem de meios para nos causar alguma pena; tudo o que sua injustiça e sua malignidade podem colocar em prática para nos afligir. Mas, levar nossa previdência e nossa apreensão para além disso é certamente nos atormentarmos voluntariamente, é encontrar com prazer motivos para nossa tristeza e nossa dor. Como o mais excelente remédio praticado fora de hora não apenas não faz bem como é capaz de causar o mal; da mesma maneira, só sofreríamos muito com as apreensões que nosso espírito conceberia sem necessidade; e a previdência das infelicidades, nos sendo muito salutar quando vemos que seremos acolhidos por elas, é muito prejudicial quando é fora da aparência com a qual elas nos chegam realmente. É preciso, portanto, que nossa apreensão seja justa, seja judiciosa, tenha um fundamento legítimo e que seja declarada pela Razão. De outra maneira, qual seria a nossa pena por estarmos perpetuamente alarmados pelas ilusões e pelas quimeras? Temermos todos os fantasmas que uma imaginação ferida e doente pode formar? É disso que nasce a necessidade, pelo contrário, de desviar nosso espírito muito cuidadosamente; de evitar a premeditação onde não temos nenhum motivo de apreensão, onde aquilo de que se tem apreensão é vão, na medida em que é imaginário e não vem de nós, e por isso vai embora do mesmo jeito que chegou, passa e se destrói a si mesmo; o remédio não é de forma alguma necessário para quem se porta bem, para quem só está doente pela imaginação. Será que não temos piedade alguma por aquele Grego cuja vida foi apenas um contínuo horror por tudo aquilo que não é capaz de causar horror algum? Que sentia apreensão, indiferentemente, por todas as coisas? Para quem o ruído do vento, o movimento das folhas de uma árvore, o latido de um cão, o canto de um galo, o relincho de um cavalo, e outras motivações ainda mais ligeiras lhe davam febre e eram percebidas por ele como desígnios e conspirações contra a sua pessoa? Que não se cria em segurança num quarto bem fechado, e sob um manto de

\footnotetext{
${ }^{93}$ No original latino, Nieremberg, nomeia a armada de Perseu.

94 Trata-se do general ateniense Nícias (c. 470 a.C.-413 a.C.), que atuou na Guerra do Peloponeso.
} 
ferro com o qual ele se cobria dia e noite ${ }^{95}$. Sem dúvida, ele sofreu muito mais com esta perpétua e vã apreensão, do que ele teria sido se tivesse sido atingido por todos os males que ele imaginava. O que diremos daquele outro infeliz que não conseguia se sentir seguro diante da visão de uma Estátua? Sua imaginação é que lhes causava pena; ela os persuadiu que eles não poderiam encontrar segurando em lugar algum, que as Cidadelas mais fortes, as torres de bronze, por assim dizer, os asilos mais invioláveis, não o eram para eles, visto que todas essas coisas não conseguiam defendê-los deles mesmos, e visto que eles não conseguiam preservá-los do mal que sua fantasia desordenada lhes suscitava. E verdadeiramente como só ela está doente, somente ela deve ser tratada, somente ela precisa de remédio. E, sem dúvida, é suficiente remediá-la, mais do que se encher de cuidados; principalmente quando a cura será tão difícil, visto que, aparentemente, não há nenhuma segurança nesse empreendimento, e visto também que por mais poderosa que seja a Razão, ela parecerá sempre incapaz de conseguir vencer. Porque, que resistência e que pena lhe causam um espírito que entra na sombra de todas as coisas? E, além do mais, não saberemos nós que é quase por milagre que se curam aqueles que são possuídos por uma Opinião envelhecida e fortalecida pelos tempos? Assim, por mais cuidado que se possa ter para lhes fazer conhecer a injustiça de suas suspeitas, por mais que se lhes faça ver que suas apreensões são vãs e sem fundamento, não conseguimos vencer seu espírito [da Opinião; ndt] e, então, eles se abandonam a isso mais fortemente, eles o temem e o multiplicam. Por mais que se lhes mostre as coisas evidentemente seguras e inocentes, eles as têm todas por suspeitas e por perigosas; sempre há, para eles, algum acidente sinistro que os ameaça; algum incômodo encontro que deve acontecer infalivelmente. Na verdade, se há algum remédio para eles, ele só vem do tempo; tudo o que é preciso esperar é o Médico das doenças desesperadas. E é isso que, agora, iremos fazer: não fazer coisa alguma a esse respeito, deixá-los até ao ponto de sua loucura passar e que eles voltem a si e que se tornem capazes de receber os conselhos da Razão. Se acontecer, portanto, que nosso espírito se ligue a uma imaginação triste e funesta, cuidemos de nos divertir tentando contradizê-la e combatê-la; nisso, é preciso que nos governemos da mesma maneira como fazemos com os impertinentes, que disputam obstinadamente sobre qualquer coisa e não conseguem parar com nenhuma razão. Como se deixa que falem tudo sem responder a nada, e como se vence melhor a eles pelo silêncio do que pelo discurso, não precisamos nos dedicar a refutar e convencer a imaginação triste e funesta; mas, de fato, tudo o que é preciso fazer é desviar nosso espírito dela, com medo de que, vindo a escutar e se prender a alguma de suas palavras, ele se deixe persuadir por ela. É preciso sufocá-la ao invés de respondê-la; tratá-la como se tratam os frenéticos, que são amarrados e trancados para que não façam mal algum. É preciso reduzi-la até ao ponto de ser vencida pelo tempo, se não puder ser vencida pela Razão. Eis o verdadeiro remédio contra esses terrores vãos e pânicos, que nos fazem não saborear os desígnios generosos, que nos desviam das boas ações, e nos impedem de progredir na Virtude. Esses terrores vãos e pânicos se ligam, ordinariamente, aos espíritos

\footnotetext{
95 No original latino, Nieremberg escreve: "Artemonem infelicem fecit stulta inanium periculorum formido. Plus laceravit illum supervacua cura, quam ipsa discrimina vexatent. Cassandrum examinavit timor statuae". O que poderia ser traduzido da seguinte forma: “Artemão ficou infeliz por causa de um temor louco por vãos perigos. Mais infeliz é aquele que se atormentou por uma diligência supérflua do que o foi de fato vexado pelos mesmos perigos. Cassandro desanimou com medo de uma estátua”. Estamos, pois, diante de dois personagens: um é Artemão, um engenheiro grego que viveu no século V a.C.; o outro é Cassandro da Macedônia (350 a.C.-297 a.C.), filho do general macedônio Antípatro (397 a.C.-319 a.C.), foi Rei da Macedônia entre 305 a.C. e o ano de sua morte, tendo fundado a dinastia Antipátrida. Segundo o historiador Plutarco, Cassandro, tendo passado perto de uma estátua de Alexandre o Grande, em Delos, teve sensação de desmaio.
} 
enfermos e doentes. Depois de lhes ter abalado os sentidos, eles abatem tão fortemente sua coragem que, para levantá-la outra vez e mantê-la na posição direita, é preciso apresentar-lhes um valor artificial, esconder-lhes o perigo, para que, não o conhecendo, eles ajam com mais resolução e não sintam nenhuma apreensão. Sem dúvida, há muitos homens que não são valentes, porque são temerários; e há homens que não têm medo porque que não têm julgamento. Este artifício não deve, porém, excluir inteiramente a assistência da Razão; é preciso empregá-la, quando o espírito voltar do terror que lhe havia feito sair de si mesmo. Porque, enquanto ela não o possui, será inútil empregá-lo. É inútil agir pela via dos conselhos e das exortações com um homem que está violentamente transportado pela cólera; é preciso esperar que ela passe, que seu sangue esfrie, e que o tumulto que se levantou em seu espírito se acalme.

\section{SEXTO ENSINAMENTO}

\section{Uso da memória}

Em seguida, vamos nos instruir acerca de um novo remédio que não tem menor eficácia do que o precedente no que diz respeito a impedir de sermos surpreendidos pelos males, e para nos dar meios de ressenti-los pouco quando eles nos chegarem. Trata-se de pensar naqueles que sofremos antes, de colocá-los em parte outra vez na memória e, em parte, bani-los, suprimi-los, enterrá-los num eterno esquecimento. Como há aqueles que não são de forma alguma enfraquecidos pelo tempo, que não passam com ele, e que só fazem se endurecer quanto mais duram, sem dúvida é preciso, para sempre, condenar o pensamento sobre eles, defender nosso espírito absolutamente de nunca mais representá-los. Se, por uma certeira e infeliz comichão de nos afligirmos a nós mesmos não conseguirmos deixar de pensar em nossas infelicidades passadas, sentimos algum prazer em descobrir nossas chagas e chega mesmo a parecer que queiramos torná-las incuráveis e mortais, então, certamente, é preciso fazer com que nossa Razão aja poderosamente, a fim de dissipar nossa dor; é preciso que ela se dedique com todas as suas forças no sentido de esclarecer as nuvens que se elevaram em nosso espírito, e se dedique também a apagar as malvadas imaginações que nos são suscitadas. Se ela não conseguir, que tenhamos a habilidade de opor a elas outras imagens agradáveis, combatendo nossa tristeza presente através da lembrança de nossa alegria passada, pensando nas coisas que felizmente conseguimos e das quais recebemos consolação e prazer. O feliz efeito deste artifício é suficientemente justificado pelo exemplo daquele famoso Escravo que tremia de alegria nos tormentos, e que suavizou o rigor de seu suplício pela satisfação de ter vingado a morte de seu Mestre ${ }^{96}$. Mas, esse remédio só serve para os espíritos fracos e tímidos, para aqueles que não têm a coragem de sustentar a abordagem e a presença dos males. Ser-nos-á muito útil também formar a imagem das prosperidades que podem nos chegar, deixar que nosso espírito passeie por toda a extensão dos, por assim dizer, vastos campos da esperança; concedendo-lhe um prelúdio dos bens que pode receber no futuro. E é nisso que terá seu uso, mas um uso inocente e legítimo, a doutrina daquele engenhoso artesão das Volúpias, Epicuro, que queria que não tivéssemos nem lembranças nem pensamentos acerca dos males, mesmo quando fôssemos o mais fortemente afligidos por eles. E que, em meio às cruzes e às

\footnotetext{
${ }^{96}$ O original latino faz referência a um certo Asdrúbal, mas não está claro a qual se refere, visto haver uma grande quantidade de personagens da história de Cartago com esse nome.
} 
perseguições da Fortuna, nosso espírito concebesse incessantemente a Ideia de coisas prazerosas e se entretivesse com aquelas que podem enchê-lo de regozijo. E, para dizer a verdade, quem nos pode impedir de prolongar nossa alegria para além de seus limites naturais? Visto que o podemos, muito facilmente, fazer através da lembrança e dos discursos. Sirvamo-nos desse meio infalível que temos para saborear dela outras tantas vezes quanto nos aprazer; esse meio de fazê-la voltar todas as vezes que quisermos; visto que este meio é tão fácil de empregar que, para praticá-lo, só nos é preciso a imaginação e o pensamento.

Quanto aos males cuja amargura passa com o tempo, que os moderou e matou, sem dúvida a lembrança nos será muito útil também; dela colheremos esta infalível vantagem: ressentir bem pouco daqueles que nos afligirem, pela comparação que faremos com aqueles do passado, que só eram tão grandes por causa de nossa Opinião, sendo, às vezes, até mesmo muito menores, não somente por não nos causar nenhuma dor, como também por nos dar alguma alegria, pela segurança que teremos de sofrermos menos e poder sofrê-los com mais facilidade. Através disso, aprendemos que o verdadeiro caráter do Sábio é ser capaz de se lembrar das coisas passadas, se dedicar às presentes e se preparar para aquelas que virão ${ }^{97}$. É preciso, portanto, que façamos uma exata consideração sobre o passado, para não cair no inconveniente de perder o inestimável fruto que deve vir disso; e não incorrer na censura de ter envelhecido inutilmente e não ter adquirido conhecimento maior do que aquele com o qual viemos ao mundo. É preciso prever o futuro e nos prepararmos para ele, para não encurtar voluntariamente a nossa vida, visto que viver sem estudar e sem conhecer as coisas futuras é morrer antes do tempo; é cortar, por nossa falta, aquela porção da vida que nos resta ainda. É, para bem dizer, nos encerrar vivos na tumba. Devemos nos lembrar que somos mortais, mas não é necessário que nos imaginemos já mortos. Certamente, se nos preparamos para sofrer, aprendemos a não sofrer. Se estudamos a maneira correta de suportar a infelicidade, nós nos garantiremos e iludiremos nossa miséria. Pensemos que os males que não nos afligem agora e que não estão presentes nesse momento, já estiveram antes, e que alguém já os ressentiu. Pelo contrário, imaginemos que aqueles que nos fazem sofrer hoje, passarão como todos os outros passaram, que, algum dia, eles não existirão mais. Ora, se eles foram vencidos pelo tempo, será que não deveriam ser ainda mais seguramente vencidos pela Razão? Será que ela não é mais forte do que ele? Será que nós acreditamos que ela tenha menos potência do que ele? Tendo colocado no esquecimento muitos males, seríamos muito fracos de nos deixarmos vencer pela apreensão de tão pouco. Como perdemos a memória desses males, não nos será difícil perder o temor. Aqueles que nos acolhem agora não são mais estranhos do que eram aqueles que nos acolheram no passado; o tempo que nos livrou daqueles nos livrará, nos curará destes; eles passarão e irão embora por si mesmos.

\section{SÉTIMO ENSINAMENTO}

\section{Proibir a inutilidade e a curiosidade da mente}

\footnotetext{
97 No original latino, Nieremberg cita, nesse ponto, um trecho de Ésquilo: “Quae opus sunt praesens dispice: ne praesens absis”.
} 
Visto que nosso desígnio sempre foi de reparar as desordens e as faltas que levam o Entendimento a pecar em relação à vontade, e de fazer esse Ministro absolutamente capaz das funções que essa Rainha espera que ele cumpra; chamaremos atenção, agora, a respeito de suas principais faltas, e em seguida vamos nos dedicar cuidadosamente a corrigi-las. Como se não fosse suficiente que ele se deixasse, de repente, surpreender pelas imposturas da Opinião, agir covardemente na conquista da Verdade, imaginá-la apenas sob Imagens falsas e lânguidas, ele ainda cai na infelicidade de correr atrás de sombras e fantasmas, encher-se de curiosidades inúteis, ocupar-se com especulações das quais, em geral, ele só tira o lamento de não ter encontrado aquilo que procurava, que são sem fundamento e não têm nem certeza nem solidez. Que loucura a nossa! Que nos leva a diverti-lo com empregos tão vãos e tão pouco dignos dele! Que nos leva a ocupar por nada aquilo que nasceu para as mais sublimes e nobres ocupações, aquilo que deve se elevar ao Céu e se ligar a Deus mesmo! Que erro! Aplicarmo-nos com tão grandes cuidados em uma ciência cujo fruto será nos tornar ociosos e preguiçosos! Que nos desviará daquilo que é absolutamente necessário que saibamos, ou seja, conhecer e fazer o bem! Que nos lançará, ou pelo menos nos entreterá na preguiça! O estudo da Virtude não é, de forma alguma, infrutífero, não é vão; é útil, é proveitoso. Para falar mais adequadamente, é não saber nada, saber apenas as coisas que não têm uso algum na vida; ser sabedor daquilo que não serve a nada é muito próximo de ser ignorante; ter vontade de aprender isso é faltar com a capacidade de julgamento e de razão, é não ser sábio. Não fingiremos em dizer que a ciência inútil não apenas não é boa, como também é má e perniciosa. E, ainda mais, ela é um obstáculo para aquela de que realmente tiramos proveito; ela nos torna negligentes na prática do bem, e nos faz, finalmente, cair no desprezo de nossa salvação. Sem mentir, o saber que só é bom para passar, e como se diz, para mandar, para enganar o tempo, é suficientemente falso e enganador. Seria entender mal o preço e a dignidade da ciência, pensar que ela só sirva para o deleite do espírito; ela não é feita somente para recreá-lo, mas também para curá-lo; seu verdadeiro uso não é para dissipar a dor, mas para corrigir o vício; ela não nos deve ser um divertimento, mas um remédio. Existirá algum doente que busca mais o prazer do que a saúde? É preciso que nos preparemos para a vida, da mesma forma como nos preparamos para uma viagem; visto que nós somos todos viajantes nesse mundo, e tudo o que fazemos é passar por aqui para irmos ao Céu. Não temos que nos sobrecarregar com equipamentos preciosos, mas tão somente do mais útil e do mais necessário. É preciso nos prover de salutares conhecimentos, que nos preservem dos ultrajes da Fortuna, da mesma forma como nos provemos de roupas que nos garantem das injúrias do ar. É ser sábio ao mais alto grau compreender a maneira de bem empregar o tempo, saber administrá-lo, não perder nenhum momento sequer, empregar até a menor parte de tempo; assim como conseguir impedir a sua prontidão e a sua ligeireza através da constância e da firmeza de nossa dedicação. A ciência tem como objetivo as coisas úteis e honestas; ela é do mesmo nível e obra mesma da Virtude. Ora, ela decai dessa honra, assim como se afasta de seu objetivo, se ela se dedicar a ocupações frívolas e inúteis. A Virtude a repudia e a bane do número das coisas que lhe pertencem; ela a subtrai do seu meio e de sua família, por assim dizer. Sem dúvida, a Sabedoria é o mais precioso ornamento do espírito, é o mais belo, o mais precioso e mais rico adorno. Mas, no entanto, adquiri-la não nos será difícil se quisermos ser realmente sábios, e não nos contentarmos em sê-lo apenas aparentemente; se buscarmos uma virtude real e sólida, e não uma virtude de amostra e de ostentação. As coisas de que realmente temos necessidade não nos custam nada para serem encontradas, se não nos distrairmos buscando aquelas que nos são inúteis. Aquilo que 
nos é necessário consiste em muito poucas coisas; e a aquisição delas não é difícil. Assim como a Vontade não será mais feliz por desejar muito, também o nosso espírito não será mais satisfeito por saber muito. Esta avareza de conhecimentos não é menos perigosa do que aquela das riquezas de objetos. Aquele é sábio não na medida em que sabe muitas coisas, mas na medida em que sabe aquelas que servem e das quais se tira algum proveito. Aprendamos a viver e não a falar; façamos fundos de boas e salutares ações, e não de belas e delicadas palavras. Protejamo-nos, assim, desse tipo de estudo que nos leva à ociosidade. Apliquemo-nos àquele estudo que produz e que mantém a Virtude; que nos faz conhecer a diferença entre o bem e o mal, que nos faz odiar e fugir deste, que nos faz amar e abraçar a outra.

Ficamos contentes por conhecer o curso e a influência dos Astros. Aprendamos que, por mais sublime e excelente que seja o conhecimento a que chegarmos, nunca poderemos nos gloriar razoavelmente de sermos sabedores e, muito menos, de sermos Sábios, se não conhecermos nossa enfermidade natural, se ignorarmos os defeitos a que está sujeita a nossa condição. Certamente é por este conhecimento que deve começar nosso saber. E, sobretudo, porque, sem ele, tudo será imperfeito e inútil. Somos curiosos por novidades; corremos atrás de coisas extraordinárias e raras. E eu vos pergunto, pode haver algo de mais novo, de mais extraordinário e raro do que ver que largamos o vício e abraçamos a Virtude? Agrada-nos conciliar os diversos e contrários sentimentos dos Outros. Não faríamos, porém, melhor conciliando nossos próprios sentimentos? Arrancando a repugnância e a contrariedade de nossos votos e de nossos desejos? Queremos instruir e corrigir os outros, e não pensamos em nos instruir e nos corrigir. Afetamos saber aquilo que se faz no mundo, e não cuidamos daquilo que devemos fazer. Estudamos tudo, menos aquilo que nos permite conhecermo-nos melhor, menos aquilo que mais nos importa. Que julgamento se fará de nós e se poderá fazer além de um julgamento muito desvantajoso, se, sabendo que nossa casa pegou fogo e vendo que várias pessoas correm de várias direções para apagá-lo, nós não corrêssemos, e nos divertíssemos considerando a forma das asas de uma mosca, contando as patas de uma lagarta, distinguindo as cores da concha de um caramujo? Insensatos que somos! Nosso coração queima de cobiça; a ambição, a avareza e o resto das paixões são fogos que o consomem; e, no entanto, nosso pensamento não se dedica a remediar isso! Não deixaríamos a casa de nosso vizinho pegar fogo; correríamos para adverti-lo, e não o faríamos perder tempo contando absurdos. E não sentiríamos vergonha, num perigo mais eminente, de nos entreter com visões e sonhos, de não nos advertir dos males intestinos que nos afligem, e não pensar de forma alguma em prevenir e em entreter aqueles pelos quais somos ameaçados. Nós dissimulamos e escondemos de nós mesmos a Sentença de morte pronunciada irrevogavelmente contra nós, na pessoa de nossos primeiros parentes. Escondemos de nós mesmos as emboscadas que a Fortuna nos prepara incessantemente; as imperfeições e as misérias inseparáveis de nossa condição. É disso que precisamos nos informar, e sobre o que devemos conversar antes de todas as coisas: se nos é permitido satisfazer à inclinação natural que temos pelo saber, se nos é permitido adquirir outros conhecimentos, se antes não formos instruídos neste. Não deixemos nosso espírito correr atrás de coisas que só podem lhe causar dor; mas empreguemo-lo na busca por meios de evitar aquilo que nos pode causar a dor. Aprendamos a sofrer com constância as infidelidades e as malícias da Fortuna, que são devidas apenas a ela, sem excitar contra ela, como costumamos fazer, nosso ódio. Aprendamos a ser pessoas de bem; a nos fazermos amar por aqueles que o são; a nos conformarmos absolutamente à Vontade de Deus; a evitarmos, o máximo que pudermos, irritar sua justiça; a nos tornarmos dignos de sua graça. Para dizer em uma só palavra, é preciso estudar a Sabedoria. É o verdadeiro 
estudo, para não dizer o único, que o Entendimento deve abraçar. Pelo menos, é aquilo no que, preferentemente, ele deve se aplicar. Certamente, as mais sublimes ciências, sem esta, são inúteis e vãs, são más e perniciosas.

\section{OITAVO ENSINAMENTO}

\section{Conhecer as coisas divinas aperfeiçoa sumamente o entendimento}

Mas, enfim, eis o ponto aonde todos esses preceitos devem chegar; há um que compreende todos; é preciso reduzi-los todos a seu princípio. É do Céu que o Entendimento recebe sua mais alta e mais pura luz; aquela que repara seus descontentamentos; que o traz de volta de sua cegueira; que corrige todos os seus enganos $^{98}$. É pelo conhecimento de Deus e das verdades eternas que vêm dEle, que é soberanamente esclarecido; é pelo conhecimento de Deus que o Entendimento chega à perfeição ou a ela aspira. Ele afasta, ele dissipa as sombras e as nuvens que ofuscam a sua claridade; ele é a causa infalível de tudo aquilo que temos de alegria; é dele que vem absolutamente nossa satisfação; é de onde procede todo o nosso bem. Certamente, quem quer que conheça a primeira Verdade é, desde esse momento, perfeitamente instruído acerca de todas as outras Verdades; visto que, para bem dizer, elas são nada mais do que ramos dessa vara, riachos dessa fonte. Esta verdade suprema as produz e as governa. Ela lhes dá o movimento, como a Engrenagem Mestra dá movimento a todas as outras engrenagens. Elas se ajustam a ela como se fosse a sua regra. Ela é a medida das outras e o nível. Diócles, aquele Sábio Filósofo, porém mais sábio pelo estudo e pela prática da doutrina de JESUS CRISTO, do que daquela de Platão e de Aristóteles, disse de forma muito excelente que quem se afasta do conhecimento de Deus se encontra em meio à extrema malícia, ou em meio à extrema estupidez ${ }^{99}$; é, para bem dizer, um Demônio ou um animal. Diócles acreditou muito justamente, sem dúvida, sendo - como é - o fundamento sobre o qual se sustentam aquelas coisas que fazem a grandeza e a dignidade do homem - quero dizer, seu Entendimento - ele decai de sua dignidade, perde todas as suas prerrogativas e todas as suas vantagens, não possui mais nada do que possa se vangloriar, se este fundamento lhe faltar; ele cai na baixeza dos animais; ele se torna inferior a tudo o que há de mais vil. Dessa forma, se eleva a revolta do apetite contra a Razão; dessa forma também, chega a revolta da parte animal contra a parte espiritual; chegam a desobediência e o transbordamento das paixões. Ora, eu vos pergunto, em que estado nos coloca esta desordem? Pode haver servidão mais vergonhosa e cruel do que aquela a que nos reduzimos? O meio infalível para evitá-la é ter o conhecimento de Deus. Ele causa a salvação do Espírito; ele coloca, ele conserva o Entendimento no mais sublime nível; ele lhe faz adquirir uma plena e perfeita luz. Mas, da mesma forma como é preciso ter os olhos sãos, a fim de ver com clareza; como é preciso purgá-los e curá-los de suas manchas e de suas doenças; é preciso, também, purgar nosso Entendimento de suas falsas persuasões e de seus erros; é preciso curá-lo da Opinião, que causa suas doenças e suas manchas; que o impede de agir com conhecimento, que lhe arranca o discernimento e se opõe, sem cessar, à liberdade de suas funções. A isso devemos, sem dúvida, dedicar todos os cuidados, pois é através

\footnotetext{
${ }^{98}$ No original latino, Nieremberg cita nominalmente o político e pensador grego Teágenes (?-c. 480 a.C.).

99 Trata-se de Diócles de Cnido, um filósofo platônico que só nos chegou graças a Eusébio de Cesareia, não encontramos informações precisas sobre este personagem.
} 
disso que vemos ou, eu ousaria mesmo dizer, é através disso que vivemos; visto que o Entendimento faz a diferença entre aquilo que nos é salutar e aquilo que não o é; pois é ele que, estando são ou doente, nos dá boas e más habilidades; ele mantém o bom ou o mau estado de nossa vida; ele nos faz amar e seguir o bem; ele nos faz detestar e fugir do mal. Assim como é pela claridade do dia que vemos os objetos distintamente, é também pelo conhecimento de Deus que julgamos de forma sã as coisas. Mas, será nossa infelicidade, será nossa malignidade, para bem dizer, estimar menos a visão do espírito do que aquela do Corpo; não nos esquecermos de nada desta última e descuidarmos daquela; achar que é indiferente tê-la como não a ter ${ }^{100}$.

Julgaremos falsa e enganadora a Opinião que temos das coisas; reformaremos nossos pensamentos e nossos sentimentos, se viermos a considerar a grandeza de nossa condição, se lembramo-nos que somos a imagem de Deus; será soberanamente feliz, sem riquezas e sem Volúpia; será cheio de glória, sem luxo e sem fausto; sua alegria precederá puramente de si; não buscará nada fora de si; e somente ele bastará. Depois disso, será que ainda somos tão pouco razoáveis a ponto de chamar de bens aquelas coisas que não pertencem a Deus e, sem as quais, ele permanece em sua suprema beatitude? Que coisas? Aquelas que são abundantes entre os malvados, possuindo as quais eles são miseráveis; as coisas que os animais mesmos possuem, e que não lhes fazem mais felizes. Será que ainda encontraremos alguém que, vendo que o soberano bem nos é proposto como a regra de todos os movimentos de nosso espírito e o fim ao qual devem aspirar todas as potências de nossa alma, ainda esteja tão enganado a ponto de acreditar que seja necessário buscar essa regra no vício? Ou que acredite que se chegue a esta regra através de más ações, pela infidelidade, pela fraude, pelo desregramento e pelas desordens que produzem, ordinariamente, as riquezas e as Volúpias? Verdadeiramente, esperar a felicidade da miséria é saber muito mal de onde ela vem; se prometer a felicidade pelas coisas onde ela não está, coisas que são absolutamente incapazes de no-la dar, que nunca serão capazes de estabelecê-la, e que, pelo contrário, a destroem; tudo isso, é saber muito mal de onde pode vir a verdadeira felicidade. No entanto, é um bem tão precioso e raro, desejado por todos, buscado mesmo pelos malvados - e, às vezes, o que é igualmente maravilhoso e deplorável é o fato de eles se tornarem malvados justamente para obtê-lo; eles renunciam ao bem para chegar até a ele; eles se tornam injustos e criminosos para se tornarem felizes. Mas, quão frustrados eles são quanto ao efeito de seu desejo? Quão vã é a sua expectativa? Certamente, eles se afastam tanto mais de seu objetivo, quanto mais imaginam se aproximar. Por um inevitável desprezo, crendo ir direto rumo à felicidade, eles irrompem e caem na miséria. Eu vos pergunto, de onde pode proceder isso, se não do fato de eles não irem pela boa via e nem sequer saberem qual é o verdadeiro caminho para a felicidade? Ora, será sabê-lo e mantê-lo sem dúvida, ir direto para Deus; considerá-lo como nossa suprema e última felicidade; buscar a abraçar a Virtude, que é uma felicidade que nos leva a outra, e que nos permite adquirir essa felicidade desde já, nesta vida. Para dizê-lo em uma só palavra, nos restringirmos à posse dos bens que dependem puramente de nós é estar em vista da chegada ao soberano bem. Talvez, me dirão: mas no que eles consistem? Certamente, em se submeter em todas as coisas à Vontade de Deus, e em lhe render uma inteira obediência; em amá-lo de todo coração; em buscar com todo o nosso poder os meios para agradá-lo e servi-lo. Através disso, adquiriremos infalivelmente a felicidade; e talvez até com a rara vantagem de nos tornarmos semelhantes a Deus; de

\footnotetext{
${ }^{100}$ No original latino, Nieremberg diz mais literalmente: "Valetudinem corporis ii aestimant, qui carent; sanitatem animi, qui habent", ou seja, "Estimam a saúde do corpo aqueles que são privados dela; a saúde da alma, aqueles que gozam dela".
} 
partilhá-la com ele. Através disso, aprenderemos a não nos ligarmos aos bens temporais e perecíveis. E da mesma forma como a linha não cresce pelos pontos, nem a superfície cresce pelas linhas, a felicidade também não aumenta pela quantidade de coisas que buscamos nesta vida. Considerando que Deus, que é o soberano bem, é constante e imutável; que ele é sempre o mesmo, que é eterno; nós excitaremos em nós a escolha pelos bens que são da natureza e da condição deste; que não são, mais do que ele, sujeitos à corrupção e ao perecimento; visto que não é pela posse dos bens da Fortuna que seremos felizes; visto que a alegria não está no meio do incômodo que ordinariamente a acompanha; visto que ela não se encontra absolutamente na inquietude que é uma seguidora infalível dela. E não pensemos que nos seja uma vantagem não conhecer seus defeitos, não creiamos que não saber que eles são caducos seja capaz de causar a nossa felicidade, que nossa ignorância possa estabelecê-la. Aqueles que embarcam num navio cujas madeiras são frágeis ou mal encaixadas não estão em segurança simplesmente por não saberem dos perigos aos quais estão se expondo. Não podemos também ser felizes apenas conhecendo sua instabilidade, na medida em que a certeza que temos disso nos mantém, finalmente, numa contínua apreensão pela perda. Dir-me-ão que, se ela chegar, não será preciso que eu tome cuidado; que, pelo contrário, é preciso que eu me console com o pensamento que, sendo, como são, vis, não vale a pena que eu me aflija. Sendo assim, como pode parecer que a felicidade, a mais nobre e mais preciosa de todas as coisas, possa ser encontrada em meio àquelas que não são dignas de nossa estima e merecem apenas o nosso desprezo?

Mas, por que tardamos tanto a dizer em alto e bom som? Todo aquele que conhece a Deus, infalivelmente se tornará sábio; quem for sábio, zombará dos enganos que a Opinião introduziu e autorizou entre os homens; ele rirá das falsas persuasões que ela lhe colocou no espírito. Não será mais possível dissimular; esta inimiga perigosa do bom senso e da Razão os seduziu e corrompeu a todos; ela os possui, e os domina; quase não há ninguém que possa se dizer isento de suas imposturas e de sua tirania. Queremos provas maiores do que suas ações públicas e ordinárias? Do que ver que eles afetam com adornos e ornamentos aquilo que, por seus sentimentos, se transforma em desonra; aquilo que sobrecarrega e incomoda? Do que ver que eles empregam as marcas da miséria para representar sua felicidade? Estranha e deplorável loucura! As pessoas de condição não apenas livre, como também felizes; aquelas que não somente não dependem dos outros, mas de quem muitos outros dependem; os Grande e os Ricos se sobrecarregam de correntes; eles não têm vergonha de rebaixar tanto a ponto de se tornarem escravos voluntariamente, privando a si mesmos da liberdade, do maior bem que recebemos da Natureza. Eles não enrubescem com a infâmia de sua servidão, porque suas correntes são de ouro; como se não fosse não ser mais escravo estar amarrado por ouro ao invés de por ferro; e como se as cadeias não fossem mais estreitas e fortes do que são brilhantes e preciosas. De qualquer forma, nisso, podemos dizer que eles são razoáveis, ao condenar publicamente sua loucura e se punirem por sua avareza, acorrentando-se por suas próprias mãos, como se fossem criminosos ou pessoas estão fora de si. Um deles, cuja loucura era mais ambiciosa que a dos outros, tendo sido, um dia, encontrado por um homem galante, lhe ofereceu motivo para fazer esta zombaria: "O resto dos loucos se deixa prender por uma única corrente, mas, no caso desse, são precisas muitas correntes”101. Há aqueles a quem não apenas o ouro acorrenta, como prega; que se vangloriam de serem perfurados, terem as orelhas rasgadas, e que gostariam muito bem de poder introduzi-lo em outras

$\overline{101}$ No original, Nieremberg se refere a um certo Nicolau, de quem não conseguimos maiores dados. 
partes do próprio corpo. Que Tirano bárbaro e tão cruel ${ }^{102}$ poderia praticar um meio mais estranho para fazer parar e reter os culpados? Quem mais poderia ter inventado a ideia de inserir as cadeias em seus membros? Quem mais poderia ter pensado em misturar e confundir as cadeias na carne e no sangue dos culpados? É isso que a avareza faz, mais cruel e engenhosa do que todos os Tiranos juntos; seguramente mais cruel; visto que, não estando contente em nos amarrar o corpo, ele nos amarra também a alma; ela nos sujeita justamente a partir daquela parte que se conserva livre em meio às mais duras provações. Estas mesmas pessoas tiram vantagem da riqueza e da pompa de suas roupas; elas fazem consistir nas roupas a sua glória. Mas, eu vos pergunto, sobre o que elas estabelecem a sua glória? Sobre um fundamento certamente muito vil e frágil, sobre o restolho vomitado por um verme, sobre o pêlo supérfluo que foi arrancado de um animal, sobre fios de seda e de lã, tecidos sutilmente e delicadamente trabalhados. Muitas vezes, chega-se mesmo a este extremo engano de julgar, através disso, os homens; de medir a nobreza e o mérito pelo seu vestuário; e, sendo mais ou menos rico, de estimar mais ou menos a pessoa que o veste. Recebemos a custa de nada e sem pena alguma a pura e a natural claridade do dia; a luz do Sol não nos custa nada; e aceitamos comprar a preço muito alto o brilho que, se não for falso, é pelo menos duvidoso, de uma pedra preciosa. Não há nada de mais belo do que o azul do Céu, que a verdura dos campos; e preferimos, no entanto, a estas duas cores, tão vivas e brilhantes, um pedaço de pedra que só tem uma tintura que representa aquelas cores tão imperfeitamente. Um engano semelhante colocou a honra em meio à abundância dos bens; ligamo-la à posse de riquezas. Disso procede que aqueles que têm muito recebem o respeito e a submissão de todos; são o objeto da reverência pública e são considerados com veneração. E, para vós, quem são essas pessoas a quem rendemos respeito e submissão? Àqueles que sabem muito bem que não são dignos; àqueles que não ignoram que os avaros são abjetos e vis; àqueles a quem tudo o que se faça para honrá-los não os toca de forma alguma e é incapaz de tirar um centavo que seja de suas mãos. Numa palavra, àqueles que esperam que nada escape dele, de uma tão grande e vasta fonte. No entanto, são honrados como pessoas de excelente mérito, se não for apenas pelo fato, talvez, de crermos que eles têm tanto, a ponto de ter impedido, pelo ardor de deglutir o bem, que outros o tivessem adquirido, e não se tornassem malvados e injustos como eles; ou, quem sabe, sejam dignos de estima, por terem agido no sentido da salvação de outros, perdendo a si mesmos. A Opinião não nos deu mais verdadeiros sentimentos da morte do que do restante das coisas, no-la tendo apresentado como má, visto que a morte, por si mesma, não o é de forma alguma, e somos somente nós que a tornamos assim. Nós nos enganamos sem dúvida ainda mais quando a imaginamos dura e terrível, porque, algumas vezes, ela é inesperada e repentina; e baseados nesta falsa persuasão, tememos o ferro, ficamos com medo do relâmpago. Certamente, teremos muito mais motivo para temer uma fruta crua; um cogumelo, um melão que nos causam cólica e, nos causando uma doença, prolongam em nós o sentimento da morte e, disso, nos faz acreditarmos que ela seja mais incômoda do que realmente é; enquanto que um golpe de espada, um raio, ao nos darem a morte logo, no-la dão sem dor e não nos deixa sentir mal algum. E, eu vos pergunto, quem é que não prefere engolir prontamente um remédio para não ter que sentir seu amargor? É ainda um engano deplorável estimar a vida mais pelos anos do que pelas obras; pela longa duração do que pelas boas ações. E este engano nos causa a tristeza extrema de não ver chegar inesperadamente a morte; de sermos surpresos antes que tenhamos tempo para pensar nisso; antes que tenhamos nos preparado para recebê-la. $\mathrm{O}$ mais ordinário e mais violento de nossos desejos é gozar a vida por muito tempo. E

\footnotetext{
102 No original latino, Nieremberg nomeia como exemplo de homem perverso e cruel o tirano Fálaris (?554 a.C.), que instaurou o Touro de Perilo como instrumento de tortura.
} 
negligenciamos incessantemente as coisas que, sendo praticadas, causarão o efeito desse desejo. Queremos viver eternamente, e nunca pensamos naquilo que é preciso para isso; ou só pensamos para protelar isso, dia após dia. Deixamos para começar a viver, quando a morte já está à porta, quando já não somos mais capazes de fazer não apenas o bem, como também o mal; quando as forças do corpo e do espírito, vindo a falhar, nos deixarão inábeis para a Virtude, como também para o vício. Sem dúvida, possuímos a menor porção da vida; elegemos aquela porção que é a pior. Nós nos lamentamos da prontidão e da subtaneidade com a qual o tempo passa; mas não fazemos nada mais voluntária e ordinariamente do que perdê-lo. Dizemos que é muito curto; mas nos enganamos, pois ele não é curto de forma alguma; ou, se o for, é apenas por causa do pouco cuidado que temos em bem empregá-lo. Não arrumemos desculpas quanto a isso; a vida dura o suficiente, ela é suficientemente longa, para quem não é ocioso. Queremos começar a bem viver quando não temos mais tempo para isso, quando está na hora de pensar em bem morrer, quando já estamos na velhice. Certamente, se formos sábios, pensaremos nela antes que ela chegue; e quando ela tiver chegado, nossos pensamentos serão todos destinados para nos prepararmos para a morte.

Portanto, é indubitável que, tendo o conhecimento de Deus, teremos as luzes necessárias para dar o justo preço das coisas; corrigiremos as falsas impressões que a Opinião nos deu sobre elas; não nos deixaremos mais surpreender por sua aparência e seu brilho. Assim, seja que as possuamos, seja que sejamos despojados delas, sempre teremos presente em nós que não há nada de bom nelas além de seu uso; que elas só valem pela escolha e pela estima que nosso espírito faz. Da mesma forma que as crianças só cuidam das pedrinhas com as quais brincam na medida em que lhes é útil para alguma coisa e, depois, as desprezam; também nós só devemos estimar as coisas na medida em que nos servem para chegar a um fim que nos foi proposto; não temos que cometer a infelicidade de tomá-las como fins em si mesmas e não devemos ligar nosso amor a elas; é preciso temer incorrer na justa censura de ter menos razão e prudência que as crianças. Como sabemos que todas elas procedem de Deus, ficaremos mais à vontade de remetê-las sempre a Ele. Elevando nosso espírito para o Céu, saberemos que há Volúpias infinitamente mais encantadoras do que todas aquelas que buscamos juntas e que saboreamos apenas através dos sentidos; Volúpias muito mais perfeitas, na medida em que não têm mais relação com os sentidos. E disso, sem dúvida, não nos dedicaremos mais a preferir aquelas Volúpias do corpo; não ignorando o quanto ele nos é pouco necessário para saborear as verdadeiras delícias, visto que Deus, que não tem corpo, possui uma soberana felicidade. Não tomaremos mais como sinal de satisfação e de alegria tudo aquilo que tem a aparência de satisfação e de alegria, aquilo que os homens fazem rindo; lembrando-nos de que os insensatos e os frenéticos riem mesmo quando um furor mais violento os transporta, mesmo quando eles se ferem com suas próprias mãos e quebram a própria cabeça contra as paredes. Certamente, por mais agradável que seja a fantasia que temos sobre as Volúpias sensuais, ela não nos tocará e não nos tentará. Pelo contrário, teremos piedade, teremos horror daqueles cuja vida é uma contínua devassidão; que, dia e noite, se enchem de vinho e de carne; que, por uma loucura semelhante àquela dos Bárbaros, adoram aquilo que os destrói; que, por uma desordem extrema, sujeitam sua alma e sua razão a seu ventre; que se estupidificam voluntariamente pelos excessos da boca e por outras dissoluções. Que grandes e remarcáveis vantagens mais podemos esperar do conhecimento de Deus? Da mesma forma como esse conhecimento nos eleva acima dos eventos humanos, também faz com que eles não nos toquem; ou, pelo menos, faz com que eles não causem uma tão grande impressão em nós a ponto de incomodar nosso repouso, a ponto de alterar nossa alegria. 
Esse conhecimento nos permite adquirir uma constância, uma firmeza, que não é abalada pelos violentos ataques que recebemos da Fortuna. Através dele, aprendemos a não temer a morte; a não amar a vida; vida que só é preciso temer na medida em que, para dizer a verdade, sendo má, fará com que a morte seja também má. O que mais eu poderia dizer? Esse conhecimento nos inspira uma alta resolução; coloca nosso coração no lugar certo, a ponto de, qualquer perigo que se nos seja apresentado, nós nos expomos com coragem, por pouco que reconheçamos nisso alguma glória da Virtude. Consideramos a vida e a morte indiferentemente; não elegemos nem temos paixão por uma mais do que pela outra, para além daquilo que um respeito tão nobre nos obriga. Se nos for necessário morrer, não apenas não resistiremos a isso, como também agiremos com alegria; e, então, não saberemos mais o que é temer o ferro e o fogo; nada de tão terrível nos assustará. Aquele que retomou a Seita dos Estoicos e reconstruiu o Pórtico, Epícteto $^{103}$, exortando seus discípulos para a prática desta Filosofia, segundo o testemunho de Arriano ${ }^{104}$, seu intérprete, lhes propunha o exemplo dos Cristãos; e, para dizê-lo com em suas palavras, construía o modelo de sua Sabedoria sobre sua loucura. Ele dava esse nome de loucura à segurança com a qual ele os via abraçarem os suplícios e se apresentarem à morte. Ele chamava loucura a mais eminente Sabedoria, a Sabedoria mesma de Deus; verificando aquilo que havia predito o divino Apóstolo ${ }^{105}$, que ela seria tomada, pelos homens, como loucura. Mas, como ele achava admirável aquela loucura! Tanto que ele propunha a imitação deles àqueles que queriam se instruir na Sabedoria! Podemos dizer, aqui, a mesma coisa: quem se curar dos erros que reinam no mundo, quem assumir sentimentos contrários àqueles da multidão enganada, não será visto como Sábio, mas certamente estará entre aqueles que não o são.

Além do mais, como o conhecimento de Deus nos confere a maravilhosa vantagem de não ficarmos descontentes na estima das coisas; como ela nos serve, nisso, de luz e de guia, sem dúvida, esta estimação mesma das coisas nos servirá de aguilhão; e, ao mesmo tempo, será uma grande ajuda para nos excitar e nos levar ao conhecimento de Deus. É através disso que as coisas, perdendo a aparência e o lustro sobre o qual se sustentam e que a Opinião lhes empresta, condenam-se a si mesmas suficientemente, se mostram bastante indignas de nossa afeição e de nossa estima, e nos fazem ver que elas merecem mesmo é nosso desprezo. Certamente, nosso espírito não seria capaz de se elevar ao Céu e se aplicar na contemplação das coisas divinas sem se separar da matéria, sem se divorciar do corpo, e, para dizer mais claramente, sem desprezá-lo. Sendo que não há nenhum caso contrário quanto a isso, em seguida, será infalivelmente necessário que quem chegou a este alto ponto de Sabedoria não se vincule a seu corpo, não tema a morte em nada, não ame nem busque as delícias, tanto menos aquilo que as produz e as mantém - as Riquezas. Como sabemos que nosso corpo é um perpétuo obstáculo para o conhecimento da Verdade, envidaremos todos os esforços possíveis para nos desembaraçarmos dele; vamos lutar ainda para romper todo comércio com ele, visto não ignorarmos que ele a causa dos males que cometemos e daqueles que nos é necessário suportar, dos males que vêm de nós e daqueles que vêm da Fortuna. Sabemos que as guerras e as desordens que existem entre os homens são feitas por causa das riquezas; sabemos que é por causa da posse do Ouro que os homens empregam o ferro para sua ruína comum; sabemos que elas causam as rapinas e as

\footnotetext{
${ }^{103}$ Epícteto (55-135).

104 Trata-se de Lúcio Flávio Arriano Xenofonte (c. 92-c. 175), que foi historiador da Roma antiga.

105 Trata-se do apóstolo São Paulo.
} 
violências que eles exercem uns contra os outros. Não ignoramos também que as riquezas são para o corpo. Se, portanto, desprezamos este, por que estimamos aquelas? Pelo desprezo das riquezas, adquirimos dois bens inestimáveis, a inocência e a liberdade; tornamo-nos Mestres de nós mesmos. E, a partir disso, conseguiremos nos devotar fortemente à contemplação das coisas divinas; através dessa contemplação, possuindo o Céu, e às vezes possuindo até mesmo a Deus, não teremos mais nem paixões nem sentimentos pelas coisas, as estimaremos pouco, visto que, sem elas, seremos soberanamente satisfeitos e felizes. Ora, sendo que isso é o objetivo a que todos visamos, sendo que não a ninguém que não aspire à felicidade, e sendo que ela é o alvo comum de todos os homens, ser-nos-á muito fácil chegar até a ela, desde que coloquemos em prática aquilo que este discurso e os precedentes acabaram de nos ensinar. Dediquemos, portanto, nisso, todos os nossos cuidados; empreguemos, nisso, toda a nossa força; visto que este é o trabalho mais nobre, o mais importante e o mais necessário com o qual poderíamos nos ocupar ${ }^{106}$.

\footnotetext{
${ }^{106}$ No original latino, Nieremberg termina o terceiro livro do De Arte Voluntatis citando uma frase de São Paulino de Nola: "Nihil de mundi sumere censu / Mens opulenta Deo voluit”.
} 